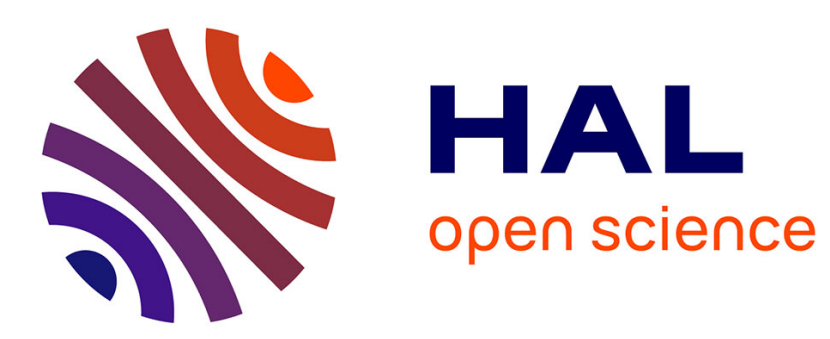

\title{
Chemical sensing with Au and Ag nanoparticles
}

Veronica Montes Garcia, Marco Squillaci, Marta Diez-Castellnou, Quy Khac

Ong, Francesco Stellacci, Paolo Samori

\section{To cite this version:}

Veronica Montes Garcia, Marco Squillaci, Marta Diez-Castellnou, Quy Khac Ong, Francesco Stellacci, et al.. Chemical sensing with Au and Ag nanoparticles. Chemical Society Reviews, 2021, 50 (2), pp.1269-1304. 10.1039/D0CS01112F . hal-03129582

\section{HAL Id: hal-03129582 \\ https://hal.science/hal-03129582}

Submitted on 2 Feb 2021

HAL is a multi-disciplinary open access archive for the deposit and dissemination of scientific research documents, whether they are published or not. The documents may come from teaching and research institutions in France or abroad, or from public or private research centers.
L'archive ouverte pluridisciplinaire HAL, est destinée au dépôt et à la diffusion de documents scientifiques de niveau recherche, publiés ou non, émanant des établissements d'enseignement et de recherche français ou étrangers, des laboratoires publics ou privés. 


\section{Chemical Sensing with Au and Ag Nanoparticles}

Verónica Montes-García, ${ }^{a}$ Marco A. Squillaci, ${ }^{a}$ Marta Diez-Castellnou, ${ }^{b}$ Quy Ong Khac, ${ }^{b}$ Francesco Stellacci ${ }^{* b}$ and Paolo Samori ${ }^{* a}$

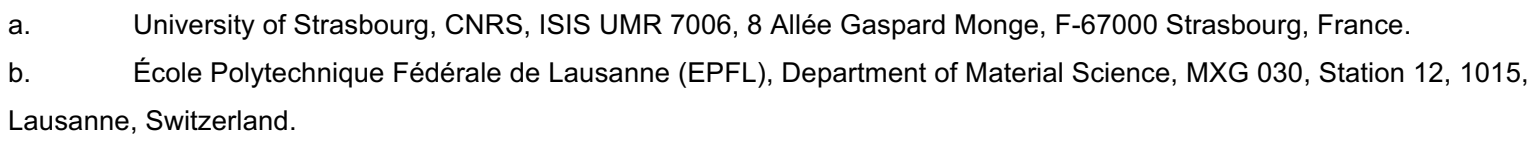

\section{Abstract}

Noble metal nanoparticles (NPs) are ideal scaffolds for the fabrication of sensing devices because of their highest surface-to-volume ratio combined with their unique optical and electrical properties which are extremely sensitive to changes in the environment. Such characteristics guarantee high sensitivity in the sensing processes. Metal NPs can be decorated with ad-hoc molecular building blocks which can act as receptors of specific analytes. By pursuing this strategy, and by taking full advantage of the specificity of supramolecular recognition events, highly selective sensing devices can be fabricated. Besides, noble metal NPs can also be a pivotal element for the fabrication of chemical nose/tongue sensors to target complex mixtures of analytes. This review highlights the most enlightening strategies developed during the last decade, towards the fabrication of chemical sensors with either optical or electrical readout combining high sensitivity and selectivity, along with fast response and full reversibility, with special attention to approaches that enable efficient environmental and health monitoring. 


\section{Introduction}

The taste of home-made food, the smell of "wet grass" after a summer storm or the intense odour of thiols in a laboratory, represent memories that we have in our mind thanks to chemical sensing. Our mouth and our nose can detect small concentrations of molecules and transform that information into an electrical signal that is then sent to our brain that processes the "data".

The efficient but often highly sophisticated mechanisms of chemical sensing developed by Nature, are a source of inspiration for the researchers working on chemical sensing.(1-3) Scientists try to mimic Nature's selectivity and sensitivity by controlling, at the nanoscale level, the required parameters ruling the interaction between an analyte and its receptor. Although chemical sensors can be part of multiple devices, they generally comprise the same two functional components: a recognition and a transducer element. While the first element provides the selective binding of the target analyte, the transducer element transforms the binding event into a measurable signal. In order to be easily readable, such a recognition event requires to be amplified into a macroscopic signal. An effective strategy towards this goal relies on the use of chemically functionalized low-dimensional structures which possess a high surface-to-volume ratio and exhibit outstanding optical and electrical properties that are extremely susceptible to changes in the environment.

Among low-dimensional structures, nanoparticles are extremely simple to be produced with good control over their size, structure and composition in large quantity, by exploiting colloidal chemistry strategies developed over the last few decades. The optical and electrical characteristics of such nano-objects can be extremely diverse and strongly dependent on the materials composing the nanoparticles. In this regard, it is possible to distinguish between three classes of materials: 1) pure metals (such as $\mathrm{Au}, \mathrm{Cu}, \mathrm{Ag}$, etc.) which feature electrical conducting behaviour and Localized Surface Plasmon Resonance (LSPR); 2) metal chalcogenides (also called "quantum dots", such as CdSe, PbS, InAs, etc.) which are semiconductors with size-dependent band gap and optical properties; and 3) oxides (such as $\mathrm{TiO}_{2}, \mathrm{ZnO}, \mathrm{SiO}_{2}$, etc.) which can be wide bandgap semiconductors or insulators. 
An in-depth discussion on the sensing strategies and performances for all the mentioned classes of materials would require a dedicated book and is far beyond the scope of this Review. Hereafter, we provide an exhaustive overview of the use of noble metal nanoparticles for chemical sensing. Among the various read-out strategies which can be employed (Figure 1), we will focus on the electrical and on the optical readouts by monitoring the changes in the NPs properties. This current review is structured in three sections. The first, highlights the distinct strategies of $\mathrm{Au}$ and Ag NPs synthesis and functionalization as well as their assembly methodologies. The second and third sections are focussed on the most enlightening recent findings on $\mathrm{Au}$ and $\mathrm{Ag}$ NPs based sensors with electrical or optical readout, respectively. Each section starts with a general introduction of the nanoparticle's properties followed by a detailed discussion on the most relevant sensing strategies which has been reported so far. Since the level of maturity and the applicability of these two different families of sensors is different, each section is sub-divided accordingly. Metal NPs-based electrical sensors is sub-divided into their application in gas and liquid media sensing. Since this field is still at its infancy, we emphasized the performances of the different sensor devices in terms of sensitivity and selectivity as well as their applicability towards e-nose/tongue sensors. Optical sensors based on metal NPs are much more established, hence major advances in colorimetric ion, small organic molecule and (bio)sensors in liquid media are discussed. Alongside, the progress on colorimetric sensor arrays for the multiplex analyte detection is also be described.

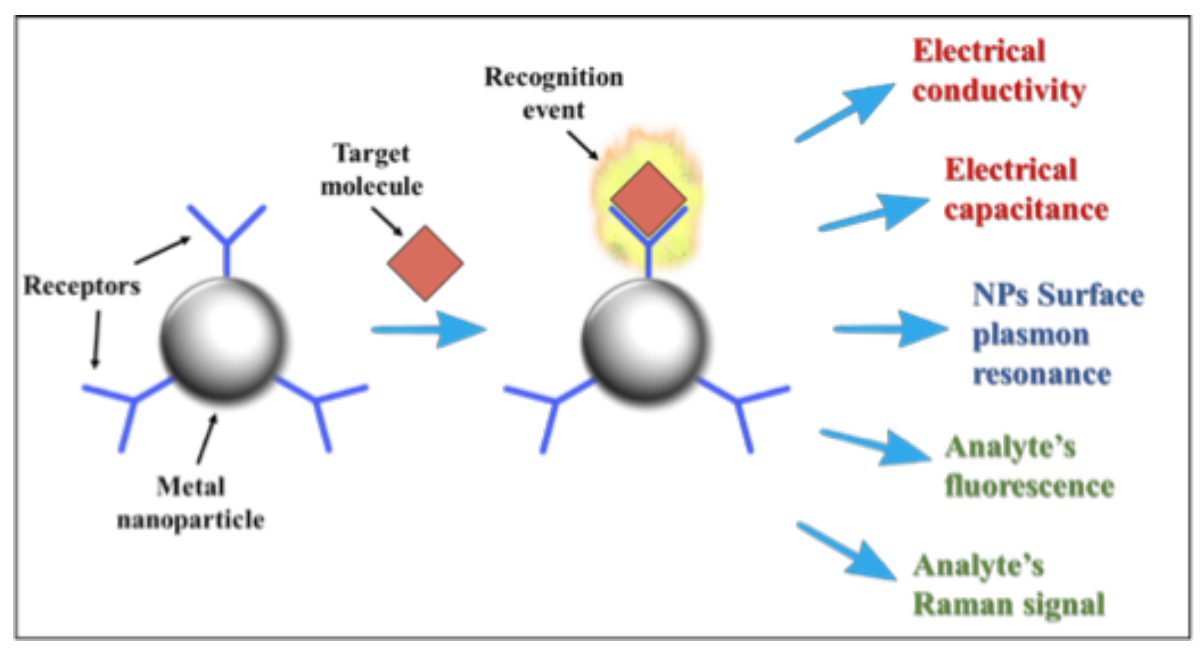


Figure 1. Scheme summarizing the metal nanoparticles-based sensing strategies (Red = electrical readout. Blue $=$ Optical readout monitoring the NPs features. Green $=$ Optical readout monitoring the analytes features).

\section{Noble metal nanoparticles: synthesis strategies}

Metal NPs have been the subject of in-depth investigations for decades because of their unique physicochemical properties and their application in several fields like photonics, electronics, catalysis, or biosensing. Since the first synthesis of metal NPs almost two centuries ago,(4) a wide variety of experimental procedures has been reported for the synthesis of metal NPs with tailored size, shape and hence physicochemical properties. The main classification of methodologies includes topdown' and 'bottom-up' approaches. $(5,6)$ While top-down approaches rely on physical manipulation (i.e. micro-patterning, lithography, pyrolysis and so on), bottom-up approaches are based on chemical transformations (i.e. chemical reduction, microemulsion techniques, microwave synthesis, and so on). Top-down approaches can be commonly classified in: i) micropatterning, ii) milling process, and iii) pyrolysis. Micropatterning methods include photolithography, scanning, soft, nano-imprint, colloidal, nanosphere and E-beam lithography. All these strategies rely on the use of a source (light/electrons beams or electrostatic forces) to form nanomaterials arrays on a solid precursor. $(7,8)$ In milling processes NPs are generated from the ground of macro-scale materials in a ball mill. $(9,10)$ Finally, in pyrolysis, the material precursor in its vapour state is forced through an orifice with high pressure and high temperature to get it burnt. NPs are then recovered from further processing of the obtained solid ashes. $(11,12)$ On the other hand, the most common bottom-up approaches include: i) chemical reduction, ii) microemulsions, iii) laser ablation, iv) radiolysis or microwavebased, and v) electrochemical methods. Chemical reduction methods are based on the use of a metal ionic salt which is reduced by one or various reducing agents in the presence of stabilizing agents. $(13,14)$ Microemulsions strategy relies on the use of two separate microemulsions containing salts and reducing agents which are mixed in presence of an amphiphile stabilizer.(15-17) The collision between the components in the two microemulsions leads to the mixing of the reactants and hence to the NPS formation. In a laser ablation process, a laser is used as an energy source for ablating solid target materials triggering the evaporation of light-absorbing species. NPs are 
generated by nucleation and growth of laser-vaporized species in a background gas.(18-20) Radiolysis or microwave irradiation involves the use of radiation (such as gamma rays or X-ray)(21) or a high-frequency wave, $(22,23)$ respectively, to heat the mixture of metallic salts and polymeric surfactant solutions, and therefore, trigger the NPs formation. Finally, electrochemical deposition occurs at the interface of an electrolyte solution containing the metal to be deposited and an electrically conductive metal substrate. $(24,25)$

Both bottom-up and top-down approaches have pros and cons.(26) Top-down approaches allow for large scale production and no chemical purification is required. However, the produced NPs feature a broader size distribution and variable morphology. Moreover, control over the deposition parameters is difficult to be achieved, the presence of different impurities can lead to the formation of defects, and the employed techniques are more expensive. On the other hand, bottom-up approaches allow for the synthesis of NPs with desired size and morphology. Synthesis parameters can be easily controlled, and employed techniques are cheaper. Yet the large-scale production cannot be easily achieved, and chemical purification of the NPs is typically required.

Among metal NPs, gold and silver nanoparticles (AuNPs and AgNPs) are the most popular scaffolds. Both support surface plasmons (SPs) in the visible (Vis) and near-infrared regions (NIR) and although AuNPs present higher chemical stability and biocompatibility, AgNPs have the highest electrical and thermal conductivity among all metals that support SPs (Al, Cu, Au, Pd, Pt and Ag). (27)

Chemical approaches are the most commonly employed for nanoparticles synthesis primarily via chemical reduction, due to the low-cost of the reactants and the straightforward tuning of nanoparticles properties by easily controlled synthetic routes. This review article will focus exclusively on the synthesis and exploitation of gold and silver NPs through chemical reduction approach.

The main three elements needed for metal NPs synthesis via chemical reduction are (1) a metallic salt precursor, (2) a reducing agent and (3) a capping agent. Capping agents act as stabilizers that avoid the aggregation of NPs which would result in the loss of their unique physical properties. The capping agents form a ligand shell exposed to the environment. Hence, the ligand shell can be chemically 
programmed in such a way to expose supramolecular receptors capable of undergoing recognition events, to ultimately selectively interact with the analyte, i.e. target molecules or ions. The typical current synthetic routes to synthesize metal NPs could be classified as 1) metal salt reduction and nanoparticle stabilization mediated by a capping agent, 2) seeded growth combined with capping stabilization, 3) green synthesis, and 4) surface modification of preformed nanoparticles.

\subsection{Metal salt reduction and nanoparticle stabilization mediated by a capping agent}

\subsubsection{Aqueous media}

The first scientific report on the synthesis of colloidal AuNPs was published in 1857 by Michael Faraday.(4) Colloidal AuNPs were synthesized by the reduction in aqueous media of tetrachloroauric acid $\left(\mathrm{HAuCl}_{4}\right)$ using white phosphorous and carbon disulphide, acting as reducing and capping agent, respectively. Nowadays, although $\mathrm{HAuCl}_{4}$ is still the most used gold salt precursor, the reducing agent used by Faraday has been replaced by less toxic compounds, like ascorbic acid or citric acid. Some decades later, in 1951, Turkevich and co-workers reported the synthesis of $\mathrm{Au}$ nanospheres in an aqueous reduction of $\mathrm{HAuCl}_{4}$ by sodium citrate, where the citrate acts both as a reducing and capping agent.(28) AgNPs synthesis was first introduced by Lee and Meisel in 1982, (29) inspired by the Turkevich synthesis of AuNPs, using silver nitrate $\left(\mathrm{AgNO}_{3}\right)$ instead of $\mathrm{HAuCl}_{4}$. When compared to $\mathrm{Au}$, the reactivity of sodium citrate with the silver precursor is different, yielding rather polydisperse $\mathrm{Ag}$ nanoparticles. In order to have more precise control over the dispersity of the AgNPs, many factors such as temperature and acidity of the solution play an important role in the size and shape of the obtained AgNPs.(30) Turkevich methodology, later refined by many others,(31-33) is the most commonly used method to synthesize quasispherical AuNPs or AgNPs with a controlled size between 10 and $40 \mathrm{~nm}$ by simply varying the ratio between citrate and the metal precursor. Although this strategy could also be applied for the synthesis of larger NPs $(>40 \mathrm{~nm})$, the obtained samples are quite polydisperse and moreover a considerable number a non-spherical NPs are produced.(31)

\subsubsection{Organic media}


Although the physisorbed shell of citrate provides colloidal stability, chemisorption offers greater and longer stability, in particular when a tightly packed self-assembled monolayer (SAM) is grown over the metal surface. $(34,35)$ Thiolated groups possess a high affinity for metal surfaces including Au and Ag, and since 1993 thiol-derived molecules have been used to chemically stabilize metal NPs. After the initial attempt of Mulvaney and co-workers of stabilizing AuNPs with alkanethiols,(36) in 1994 Brust and Schiffrin reported the synthesis of thiol-protected AuNPs in a twophase system consisted of water and toluene.(37) Hydrophobic AuNPs were obtained by reducing gold(III) ions with a strong reducing agent, sodium borohydride $\left(\mathrm{NaBH}_{4}\right)$, in the presence of a large excess of dodecanethiol and using tetraoctylammonium bromide (TOAB) as phase-transfer agent, which brings the gold(III) ions from water to toluene, where the NPs synthesis takes place. A variant of this methodology has been used for the synthesis of AgNPs by using allylmercaptane as a capping agent and TOAB and $\mathrm{NaBH}_{4}$ as phase-transfer and reducing agent, respectively.(38) These syntheses, although producing great advances in the past 25 years $(39,40)$, exhibit three main drawbacks: 1) as a result of the strong reducing conditions, only specific molecules containing well-defined functional groups can be used to form the coating SAM; 2) the use of a large excess of these molecules is quite problematic in the case of expensive compounds, and 3) NPs size can be controlled up to only $5 \mathrm{~nm}$. In 2006, Stucky and co-workers reported the synthesis of thiol-protected AuNPs in one phase - an organic solvent such as benzene, toluene or chloroform - using a gold(I) salt as precursor and a mild reducing agent such as tert-butylamine-borane complex.(41) This synthesis enabled a greater control over the production of mono-disperse NPs and allowed the use of thiolated molecules exposing a functional group in the $\omega$-position to readily form functional coating SAMs that could not be grown by using the previously introduced methodology. Unfortunately, this protocol still suffers from the drawback of requiring a large excess of thiolated molecules and a maximum diameter of $10 \mathrm{~nm}$ NPs can be obtained if one likes to have monodisperse sizes.

\subsubsection{Alcohol media}

Polyol process is an advantageous, versatile, and low-cost method for the synthesis of both Au and Ag NPs on a large scale. $(42,43)$ A metal salt is dispersed in a long-chain diol such as ethylene glycol that acts both as a solvent and as a reducing 
agent. After the reduction, the resulting particles are non-agglomerated and monodisperse, with a tuneable size that can span from 20 up to $200 \mathrm{~nm}$. Yet, the produced NPs are not spherical, but rather polyhedrons or plates with stable surface facets. Temperature, reagent concentration and presence of trace ions seem to play a key role for the final NPs morphology. $(42,43)$ In 2013, a new synthetic method based on a reiteration of slow growth process and slow chemical etching has been reported, allowing the preparation of highly spherical AuNPs of up to $200 \mathrm{~nm}$ diameter (Figure 2).(44)

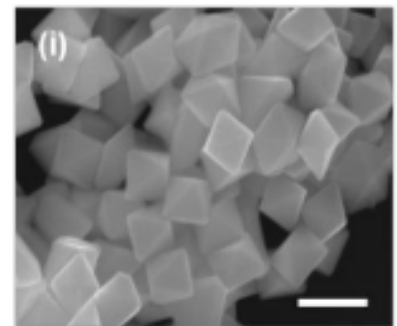

$135.4 \pm 12.5 \mathrm{~nm}$

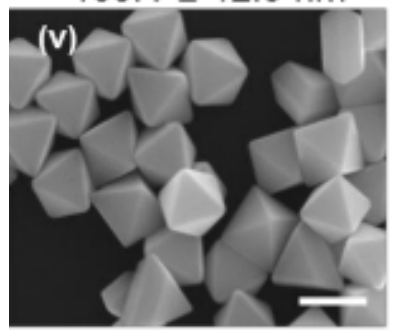

$173.3 \pm 15.1 \mathrm{~nm}$

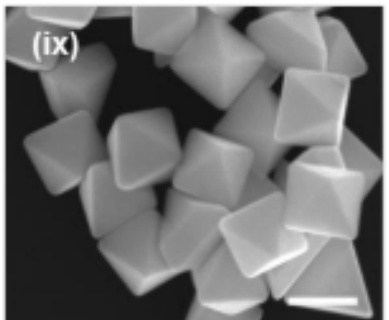

$197.5 \pm 17.3 \mathrm{~nm}$

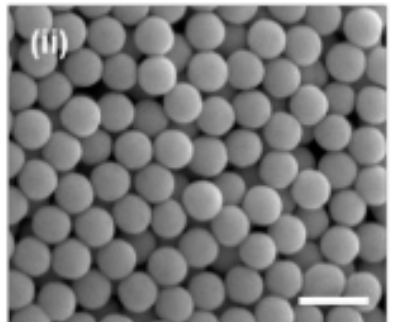

$112.3 \pm 8.2 \mathrm{~nm}$

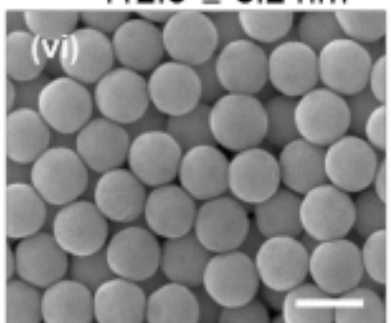

$149.6 \pm 10.8 \mathrm{~nm}$

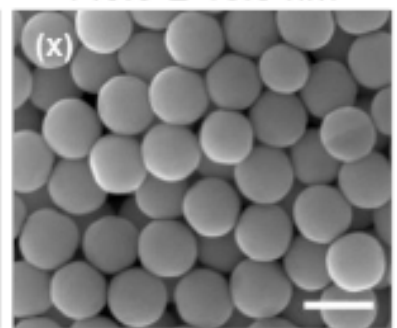

$172.4 \pm 12.3 \mathrm{~nm}$

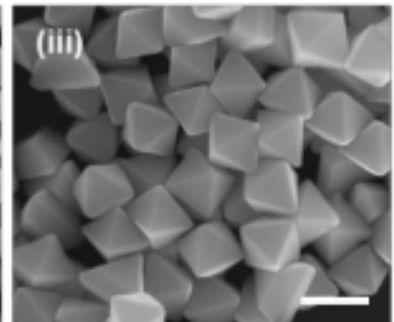

$156.5 \pm 13.8 \mathrm{~nm}$

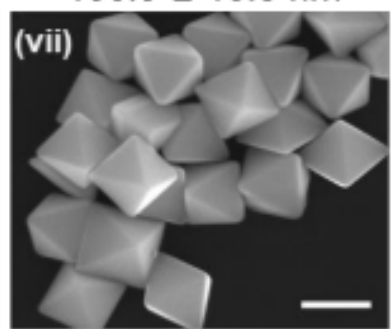

$187.2 \pm 16.4 \mathrm{~nm}$

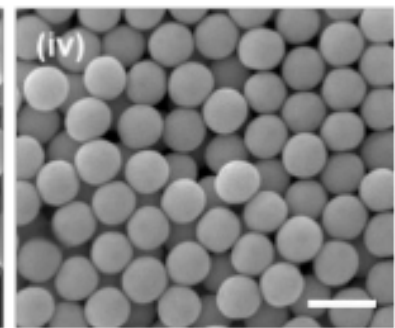

$131.2 \pm 9.5 \mathrm{~nm}$

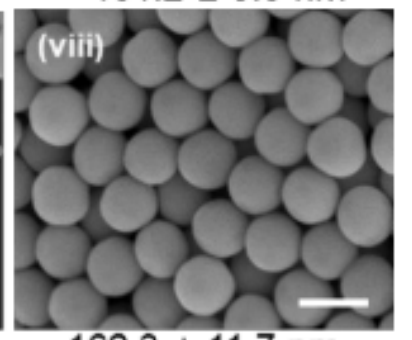

$162.3 \pm 11.7 \mathrm{~nm}$

Figure 2. Iterative growth and etching of gold octahedra. (i-x) SEM images of gold octahedra and nanospheres after iterative growth and etching. (i) initial growth, (ii) $1^{\text {st }}$ etching, (iii) $1^{\text {st }}$ regrowth, (iv) $2^{\text {nd }}$ etching, (v) $2^{\text {nd }}$ regrowth, (vi) $3^{\text {rd }}$ etching, (vii) $3^{\text {rd }}$ regrowth, (viii) $4^{\text {th }}$ etching, (ix) $4^{\text {th }}$ regrowth, $(x) 5^{\text {th }}$ etching. Average particle sizes, indicated below each image, refer to edge length for octahedra and diameters for spheres. White scale bars indicate a lateral size of $200 \mathrm{~nm}$. Adapted with permission from reference (44). Copyright 2013 American Chemical Society.

\subsection{Seeded growth combined with capping stabilization}


For the synthesis of uniform and large spherical as well as non-spherical NPs, seeded growth strategies have been proved to be one among the most efficient protocols to be pursued. The seeded growth method comprises two steps: the synthesis of a batch of NPs and its overgrowth by its addition to a "growth" solution containing a metal salt precursor (commonly $\mathrm{HAuCl}_{4}$ or $\mathrm{AgNO}_{3}$ ), and capping and reducing agents. Size, shape and surface properties are controlled by several parameters including the amount and nature of the capping and reducing agent, their molar ratio to the metal salt precursor, etc. Natan and co-workers pioneered in 1998 the use of seeded growth method to synthesize Au nanospheres up to $100 \mathrm{~nm}$ in diameter.(45-47) The strategy is based on the overgrowth of $12 \mathrm{~nm}$ Au seeds using citrate or hydroxylamine as a reducing agent. However, both reducing agents possessed drawbacks; while the obtained NPs were rather elongated with citrate, a considerable population of rod-shaped NPs was obtained by using hydroxylamine as a reducing agent. Following the strategy developed by Natan and co-workers, a great number of seeded growth methods have been developed for the synthesis of uniform and large Au nanospheres.(48-54) For instance, Murphy and co-workers (48) proposed a step-by-step seed-mediated growth strategy utilizing ascorbic acid as reducing agent and cetyltrimethylammonium bromide (CTAB) as a capping agent. Interestingly, CTAB also played an important role in complexing the gold salt precursor and avoiding its self-nucleation by ascorbic acid reduction. Such protocols enabled the synthesis of gold NPs with controllable size from 5 to $40 \mathrm{~nm}$ using citrate stabilized gold NPs as seeds. Moreover, since nucleation was avoided during the growth step, the final particle size could be estimated through the following equation:

$$
r=r_{\text {seed }}\left\{\frac{\left[M_{\text {added }}\right]+\left[M_{\text {seed }}\right]}{\left[M_{\text {seed }}\right]}\right\}^{1 / 3}
$$

where $r_{\text {seed }}$ and $r$ are particle radius for seed and final desired particle, respectively, and $\left[M_{\text {seed }}\right]$ and [ $\left.M_{\text {added }}\right]$ indicate gold concentrations of seed and added $\mathrm{Au}^{3+}$ ions, respectively.(48)

Similar to the method of Murphy, AgNPs with narrow size distribution had been prepared by seed-mediated growth using modified Frens and Lee-Meisel methods.(55, 56) Furthermore, other reducing and capping agents have been employed, such as 2-mercaptosuccinic acid, (57) hydroquinone $(50,58)$ or $\mathrm{H}_{2} \mathrm{O}_{2}(53)$ 
making it possible to control the size of the obtained Au or Ag nanospheres up to 300 $\mathrm{nm}$ in some cases. For example, Bastús and co-workers developed a multistep seeded growth methodology to synthesize monodisperse citrate-stabilized AuNPs (52) or AgNPs (14) up to $200 \mathrm{~nm}$ in both cases with narrow size distributions and slight deviations from sphericity. Chemical reduction of $\mathrm{HAuCl}_{4}$ or $\mathrm{AgNO}_{3}$ was accomplished by using respectively sodium citrate as both reducing and capping agent (Figure 3 ) for AuNPs and a mixture of sodium citrate and tannic acid as reducing agent for AgNPs.

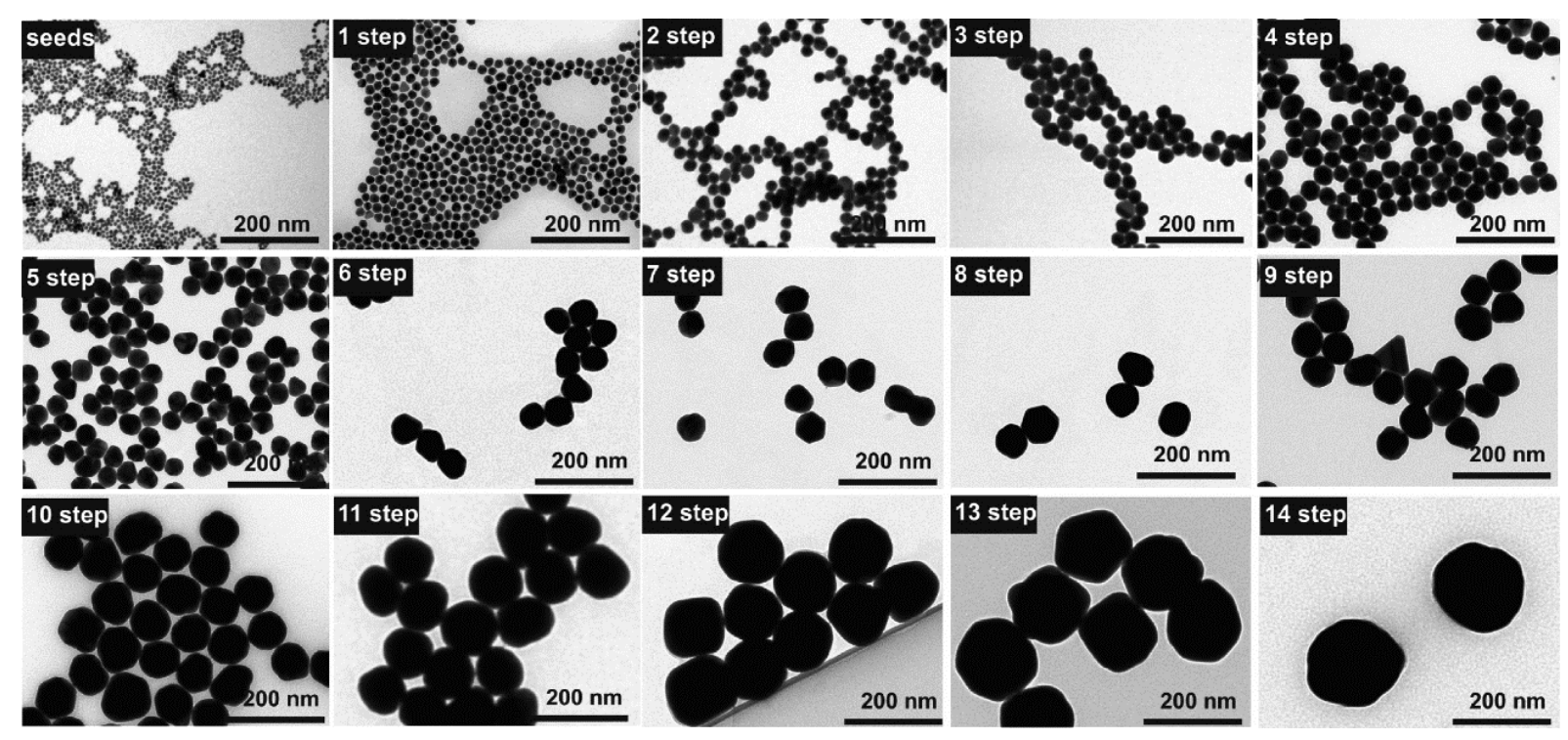

Figure 3. Transmission electron microscopy images of AuNPs obtained after different growth steps using Bastús and co-workers seeded growth methodology. Adapted with permission from reference (52). Copyright 2011 American Chemical Society.

\subsection{Green synthesis}

Synthesis of metal NPs by using green methods is an emerging trend in nanotechnology. $(59,60)$ It exploits the same mechanism of the Turkevich method yet it relies on specific initial building blocks which are a metal salt, a green solvent (water, ethanol or other non-toxic solvents) and a natural reducing agent. Frequently, most green materials that can act as reducing agents possess a stabilizing ability (e.g. due to the presence in the extract of different reactive groups). For the case of bio-reagents the possibilities of reducing agents can be endless, highlighting bacteria,(61) fungus, $(62,63)$ enzymes,(64) plants,(65-67) yeast,(68) algae (69) or biopolymers.(70) 
This methodology has some advantages when compared to other physical and chemical methods because it is a cost effective, eco-friendly method, and can be easily scaled up for large scale production. Also, green synthesis does not involve use of high pressure, energy, temperature and toxic chemicals. However, unlike physical and chemical synthesis, there are still many unknown factors that should be studied in detail. In many cases the mechanism of production is indeed still unclear. Moreover, the exact amount and properties of the reducing agents should be determined in order to establish precise and repeatable synthetic protocols.

\subsection{Surface modification of pre-synthesized nanoparticles}

The functionalization of metal nanoparticles with other molecules can otherwise be achieved by direct covalent linkage or non-covalent interactions with presynthesized nanoparticles (Figure 4). (26) This strategy enables to use a wide range of organic molecules as capping agents, including surfactants, macrocycles and biomolecules thus opening endless options to obtain selective interaction with the desired analytes. Towards this end, two main strategies can be pursued: ligand exchange reaction or secondary modification.

\subsubsection{Ligand exchange reaction}

A well-established route for the post-modification of metal nanoparticles consists in the use of thiol molecules because they strongly bound the metallic surface through a covalent bond (M-S).(36) For instance, Abd-elaal and co-workers synthesized AuNPs by reducing gold(III) ions with trisodium citrate, followed by its displacement by the desired thiolated molecules in a mild process.(71) Other functional ligands can covalently bond metallic surfaces such as metal carbon $(M-C=)$ by using aryl diazonium as precursors, $(72)$ metal-carbene $(M=C)$ or metal-nitrene $(\mathrm{M}=\mathrm{N})$ with diazo derivatives (73) and metal-acetylide/-vinylidene via acetylene derivatives.(74)

Surface modification of metal NPs can also be accomplished with amines or ammonium ions, negatively charged carboxylate groups, and phosphines. For instance, Perez-Juste, Pastoriza-Santos and co-workers performed a ligand exchange reaction between a pillar[5]arene macrocycle with five quaternary ammonium groups 
at both rims and the stabilizing agent of the as-prepared NPs. They applied this approach to plasmonic nanoparticles either negatively charged, stabilized by citrate ions (Au spheres), or positively charged, stabilized by cetyltrimethylammonium bromide ( $\mathrm{Au}$ and $\mathrm{Au@Ag} \mathrm{nanorods)} \mathrm{demonstrating} \mathrm{the} \mathrm{high} \mathrm{versatility} \mathrm{of} \mathrm{this}$ strategy.(75)

\subsubsection{Secondary modification}

Secondary modification is also commonly employed when a reaction is performed between the new functional molecule and the capping agents of the metallic nanoparticles. The secondary reaction can be accomplished by using chemical coupling, $(76,77)$ employing dynamic covalent bonds, $(78,79)$ polymerization, $(80,81)$ electrostatic interaction and interaction between biomolecules(82, 83). For example, metal nanoparticles functionalized with carboxylic acid-terminated thiol ligands readily form amide linkages with other molecules through EDC-NHS coupling.(76)

Both strategies have advantages and limitations. Ligand exchange reaction relies on the displacement of the initial capping agents of the NPs by other ones possessing a higher affinity (usually through the formation of a covalent bond). Although this functionalization gives rise to a highly stable NPs, it is limited to molecules with the appropriate functional groups, such as thiols. Secondary modification represents a highly versatile strategy for the functionalization of the NPs with the receptor of interest. However, receptors with proper functional groups to react with the capping agent of the NPs are needed. A combination of both strategies could also be used in many cases to further increase the versatility of post-synthetic functionalization. 


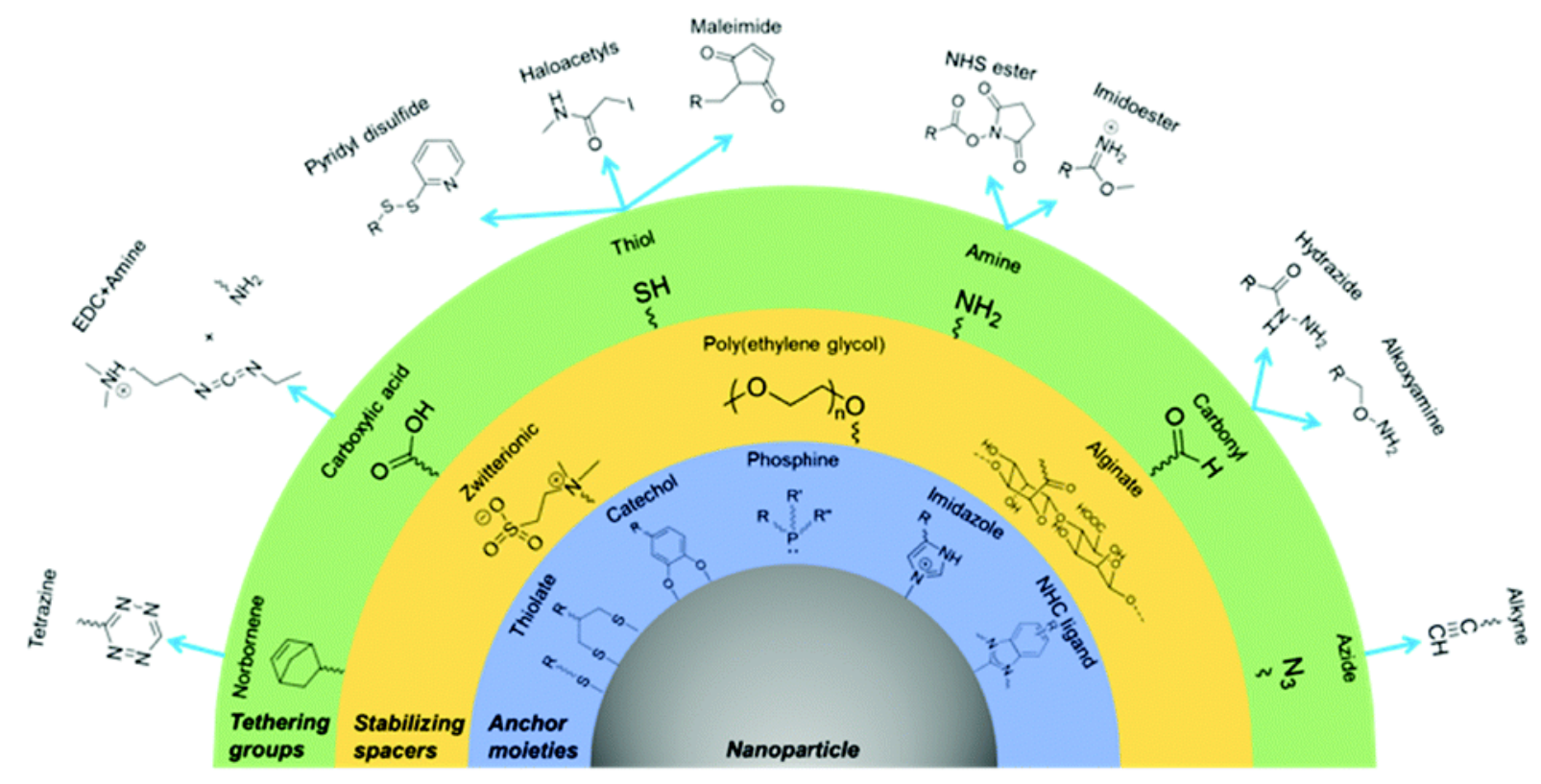

Figure 4. Schematic illustration of representative anchor moieties, stabilizing spacers, tethering groups, and conjugation groups for functionalising noble nanoparticles. $\mathrm{NHC}=\mathrm{N}-$ heterocyclic carbenes, NHS $=$ N-hydroxysuccinimide, EDC = 1-ethyl-3-(3dimethylaminopropyl)carbodiimide hydrochloride. Reproduced from Ref. (26) with permission from the Royal Society of Chemistry.

\subsection{Assembly methodologies}

Distinct methods can be used to deposit metal NPs to form networks on solid surfaces yielding assemblies that exhibit different properties (e.g. structure, morphology and size) and hence different sensing capabilities.

I. Casting methods enable the production of thick and relatively disordered films of metal NPs.(84-86) A solution of metal NPs is spread onto a solid substrate by a casting methodology (drop cast or spin coating). When the solvent is evaporated it triggers long-range dispersion forces between the NPs or between the NPs and the substrate causing the NPs to selforganize into mono- or multilayer structures. The separation between the NPs can be controlled by the size of the capping agent but may be also modified after the casting process by either ligand substitution reaction or the annealing of NPs.

II. Langmuir methods are usually employed to prepare a monolayer of ordered metal NPs. $(87,88)$ Frequently, a solution of metal NPs stabilized 
with hydrophobic capping agents is casted on the surface of an aqueous solution. Due to the surface tension of water, the hydrophobic NPs tend to form a monolayer film at the air-water interface. Such film can be slowly compressed and transferred onto a solid substrate. Such a method could be repeated to produce multilayer arrays of close-packed NPs. A great benefit of the Langmuir approach is that it offers precise control over the film thickness and interparticle distance.

III. Casting assisted by cross-linking method relies on the combination of metal NPs with linker molecules yielding the assembly in solution. $(89,90)$ Such network is transferred to a solid substrate by dipping the latter into the liquid. Film thickness is usually controlled via the immersion time of the solid substrate into the reaction mixture.

IV. Layer-by-Layer (LbL) assembly represents the most versatile methodology for the formation of 3D assemblies of metal NPs onto solid substrates. It consists in the alternate immersion of a solid substrate into metal NPs and linker solutions. (91-93) By making use of this strategy a wide variety of interactions may be explored such as electrostatic, covalent bonding or hydrogen bonding and hence a broad array of linker molecules can be employed.

Among the different methodologies, although Langmuir methods and LbL assembly allow for the fabrication of a film with controllable thickness, these methodologies are rather time-consuming. On the other hand, casting and casting assisted by cross-linking methods are more simple and faster methodologies but the final film thickness and morphology are difficult to control.

\section{Electrical properties}

Nanoparticles can be tailored with different dimensions and the latter, together with the chemical composition and structure, define the properties of these nano-objects. From the electrical point of view, the behaviour of metal nanoparticles is strongly correlated to the number of atoms forming the core, as emphasized by the equation of the Kubo gap (ס):

$$
\delta=\frac{E_{F}}{N}
$$


where $E_{F}=$ Fermi energy of the material and $N=$ Number of atoms within the core.

In a nutshell, this simple equation indicates that by decreasing the number of atoms forming the nanoparticles' core, the energy levels are quantized opening a gap thereby rendering the material insulating, as schematized in Figure 5.(94) According to the Kubo model, for materials like Au and Ag, if the nanoparticles have a diameter larger than $\sim 2 \mathrm{~nm}$, they behave electrically as the bulk material, and can be employed as nanoscopic electrical conductors complying to the Ohm/s law.

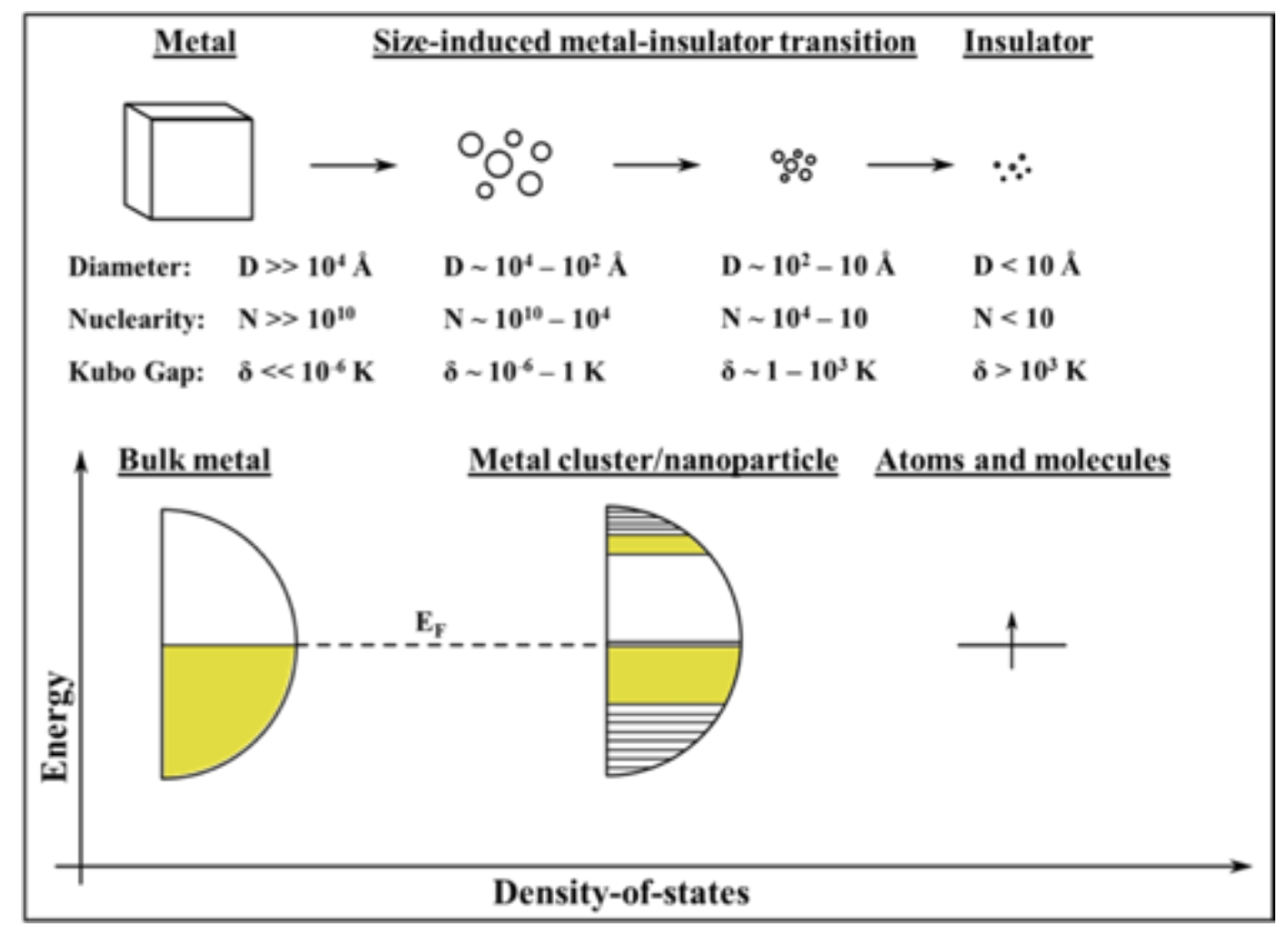

Figure 5. Schematic diagram showing the size-dependent evolution of the energy level of metals. Adapted from Ref.(94) with permission from The Royal Society of Chemistry.

\subsection{Electrical sensors: Chemiresistors}

A viable strategy to efficiently exploit the advantages of such small metal conductors is to assemble them into networks to generate thousands of electrical junctions with controlled nanoscopic gaps by employing the 
nanoparticles as electrodes and the capping agents as spacers.(95) Such bicomponent networks can be used as versatile sensing materials in chemiresistors devices.(96) Chemiresistor-type devices quantify the electrical resistance as a response to chemical or biochemical stimuli.(95, 96) A basic chemiresistor architecture comprises a sensing material that bridges the gap between interdigitated electrodes in two terminal devices. In such devices, the organic components attached to the particle's surface provide stabilization of the structure and represent sites for the analyte absorption/binding while enabling sufficient electrical conductivity through the film, as illustrated in Figure 6.

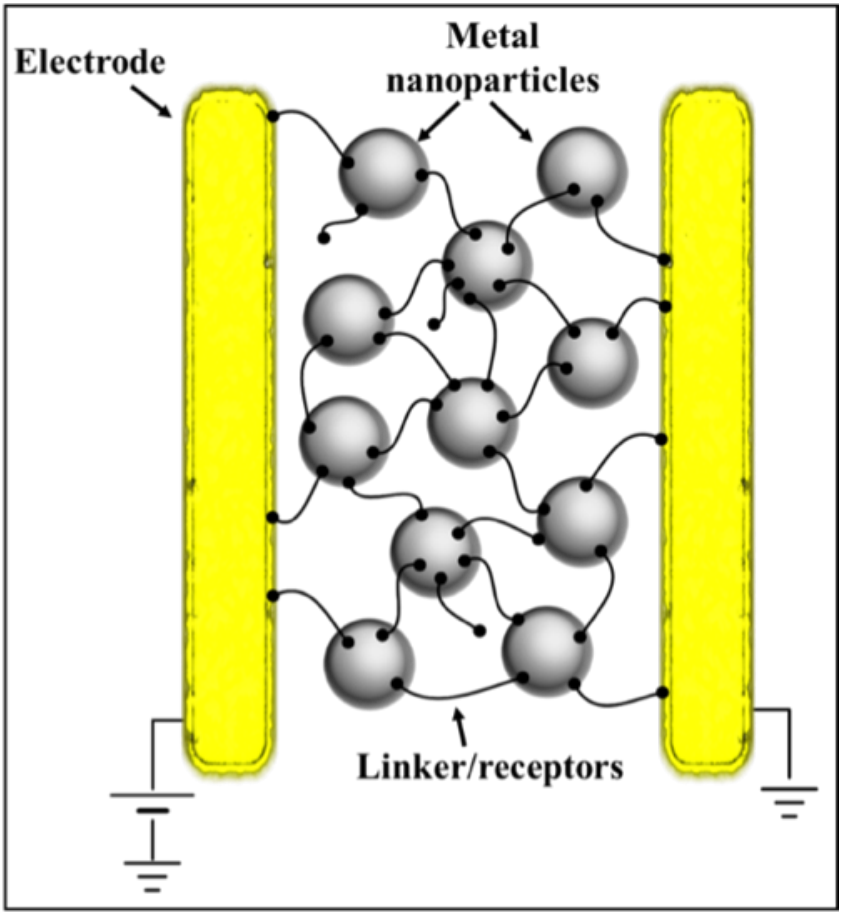

Figure 6. Scheme of a generic chemiresistor device based on metal nanoparticles and organic di-thiols.

The electrical transport properties of metal nanoparticles films are governed by the different energy scales and geometrical parameters characterizing their architectures. In principle, the electrical resistance of a network composed of infinite particles can retain any value between two limit states: (1) a completely insulating state when all the nanoparticles are widely spaced between each other and (2) a metallic state when the particles are arranged in a close packed structure and behave as a whole bulk metal with ideally no contact resistance. (89) Nevertheless, the organic matrix surrounding the nanoparticles plays a key 
role in controlling the electronic coupling between neighbouring particles but also some secondary parameters such as particles size, geometrical defects and quenched charged disorder in the arrays, and/or the substrate will also influence the electrical transport properties of the arrays.

\subsection{Electrical measurements}

In the most straightforward configuration, a bias voltage $(\mathrm{V})$ is applied across two electrodes supported on a solid substrate and the resulting current (I) can be measured (Figure 7A).(97) According to Ohm's laws, which is often valid for many materials type, at low voltages and for metals, current can be described as linearly proportional to voltage:

$$
I=g V=V / R
$$

where $g$ is the conductance and $R$ is the resistance of the material between the two electrodes.

Interdigitated array (IDA) electrodes (Figure 7B) comprise several electrode finger pairs, typically microns in dimension. IDA electrodes can be fabricated not only onto insulating rigid substrates such as $\mathrm{Si} / \mathrm{SiO}_{2}$, glass, or quartz, but also onto flexible substrates such as polyethylene terephthalate (PET) using photolithographic patterning. The conductivity $(\sigma)$ of a film deposited onto IDA electrodes can be calculated using the following equation(98),

$$
\sigma=\frac{d}{(2 N-1) L h} g
$$

where $\mathrm{d}$ is the spacing between electrodes, $\mathrm{N}$ is the number of finger pairs, $L$ is the overlapping length of electrodes, $h$ is the film thickness (less than that of IDA electrodes).

The electrical conductivity of thin films composed of ligand-stabilized metal NPs is commonly described by thermally activated tunnelling of charge carriers. A widely used mathematical representation of this model is given by the following equation (99):

$$
\sigma=\sigma_{0} e^{-\beta \delta} e^{-E a / k_{B} T}
$$


A

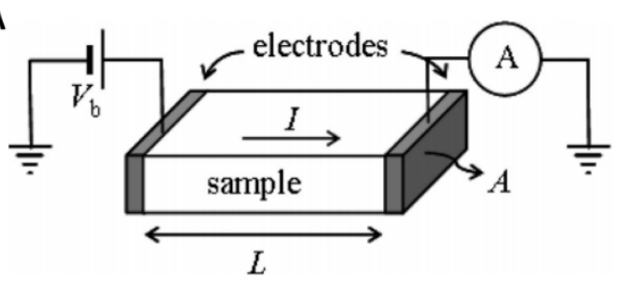

B

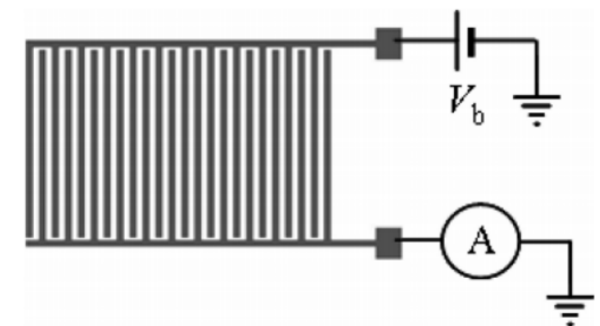

C

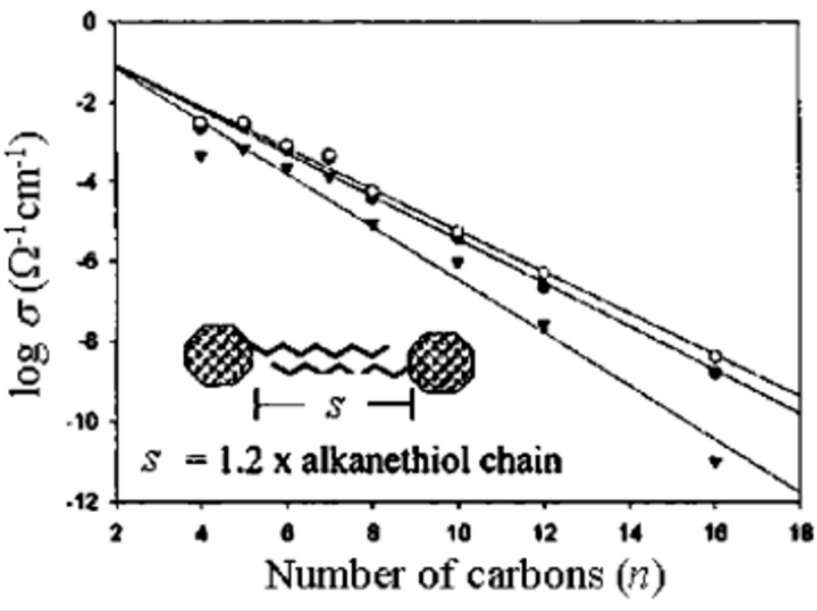

Figure 7. Schematic of (a) a two-probe electrode configuration, and (b) IDA electrodes. (c) Conductivities of films of $\mathrm{CH}_{3}\left(\mathrm{CH}_{2}\right)_{\mathrm{n}-1} \mathrm{~S}$-capped $2.2 \mathrm{~nm}$ Au NPs at $70(\mathrm{O}), 30(\bullet)$, and $-60{ }^{\circ} \mathrm{C}$ $(\boldsymbol{\nabla})$ vs $\mathrm{n}$. The inset is a schematic illustrating interdigitation of capping ligand chains in the NP films. Adapted with permission from (97). Copyright 2008 American Chemical Society.

Here, $\sigma_{0} e^{-\beta \delta}$ is the conductivity at infinite temperature, $\sigma_{0}$ is the preexponential constant, $\beta$ is the tunnelling decay constant, $\delta$ is the interparticle distance and $\mathrm{K}_{\mathrm{B}}$ and $\mathrm{T}$ are the Boltzmann constant and the temperature respectively. The Arrhenius term takes into account thermal activation of charge carriers and can be described as:

$$
E_{a}=0.5 e^{2} \frac{r^{-1}-(r+\delta)^{-1}}{4 \pi \varepsilon \varepsilon_{0}}
$$

Where $r$ is the nanoparticle radius.

Because of its exponential dependence on Ea and $\delta$, the conductivity of these films is highly sensitive to any perturbation of these parameters, including interaction with a targeted chemical species.

The complexity of these systems is illustrated by investigating their electrical properties. Since charge carriers can move following different pathways and different transport mechanisms, it is not enough to perform simple I-V electrical measurements. It is indeed necessary to perform low temperature studies and using bi-component structures featuring different inter-particles distances. In 2013, Liao and co-workers reported a study on the electrical properties of gold nanoparticles films of different thickness and inter-particles spacing, in a temperature range ranging from 5 to $300 \mathrm{~K}$ (Figure 8).(100) 

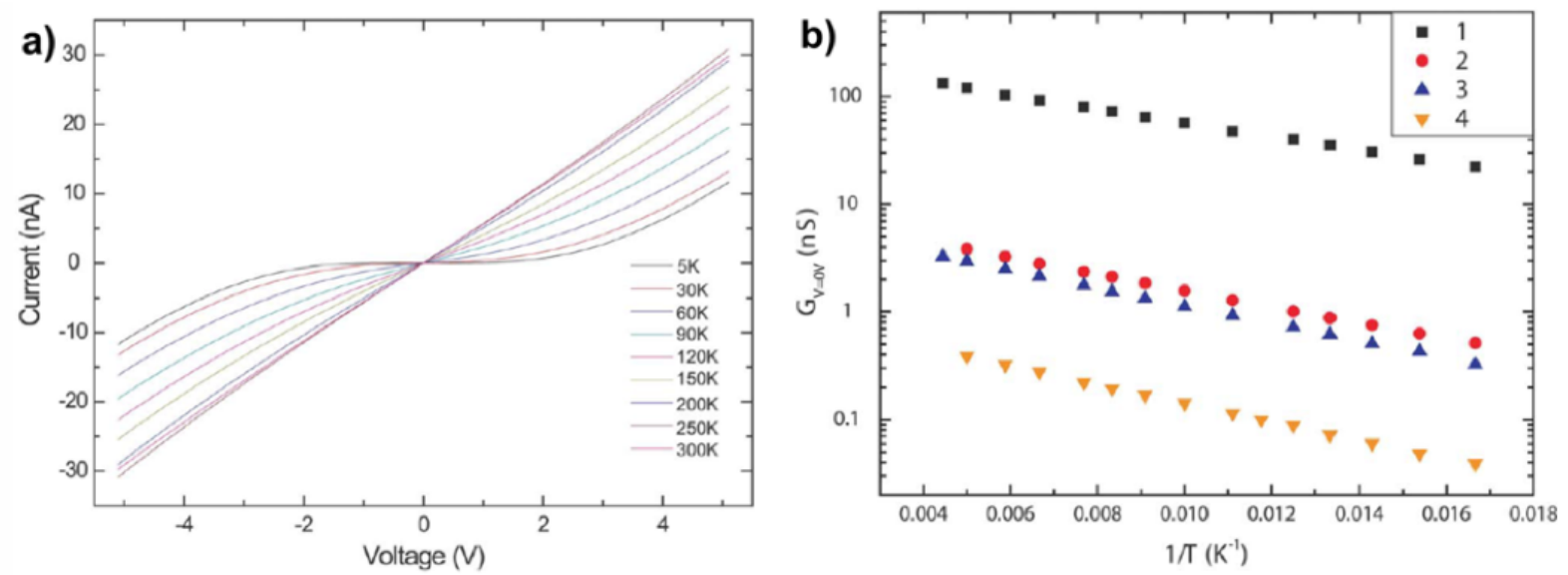

Figure 8. Temperature dependent charge transport. (a) I-V curves of interlinked 2D nanoparticles arrays measured at variable temperatures from $5 \mathrm{~K}$ to $300 \mathrm{~K}$. (b) Zero-voltage conductance of the nanoparticle arrays as a function of inverse temperature for nanoparticle arrays with different inter-particle distances, where 1) butanethiol; 2) hexanethiol; 3) octanethiol; and 4) decanethiol. Adapted from Ref. (100) with permission of the Royal Society of Chemistry.

From the I-V curves in Figure $8 \mathrm{~A}$, it is visible that the relationship between measured current and applied bias becomes less and less linear upon decreasing the temperature. When the temperature is low enough, the current at low bias is suppressed due to Coulomb blockade. Such phenomenon relates to the Coulomb charging energy of a nanoparticle, which is defined as the energy needed to add an excess electron onto a neutral nanoparticle.(96)

Theoretically, in the I-V curves of nanoparticle arrays at low temperature, a threshold voltage should exist below which the current is completely suppressed.(97, 101). Figure 8B portraits the zero-voltage conductance of the nanoparticle arrays as a function of inverse temperature. In this case nanoparticle arrays are functionalized with alkanethiols exhibiting different chain lengths (particles diameter $9.25 \mathrm{~nm}$ ). It reveals a strong dependence of the conductivity on the inter-particles distance.(100)

Thus, applications of films fabricated from ligand stabilized metal NPs as resistive sensing elements have been studied intensively and pushed toward specific applications in several laboratories. In the following sections we are going to summarize the main progress that has been done in the field of metal nanoparticles-based chemiresistors in the last decade. 


\subsection{Metal NPs chemiresistors in gas sensing}

In 1998, Wohljen and Snow developed the first example of a metal nanoparticles-based chemiresistor for vapor sensing. They fabricated a device comprising a film of octanethiol-capped AuNPs on interdigitated electrodes and exposed it to various volatile compounds: toluene, tetrachloroethene, 1propanol and water humidity.(102) Exposure of the nanoparticles arrays to the target analyte molecules causes swelling of the structure, commonly leading to an increase of the resistance of the device.(103-106) This sensor exhibited a quick and reversible response towards the uptake of vapor molecules in the interparticle organic phase, affecting the electronic interaction between the nanoparticles and hence the conductivity of the film.(102) Since then, numerous studies have been carried out focusing on sensor performance improvement in terms of sensitivity and selectivity.

\subsubsection{Sensitivity enhancement}

Chemiresistors offer a versatile configuration which allow to modulate the electronic transport through the networks by controlling the nature and the conformation of both the metal nanoparticles and/or the organic molecular linkers.(107)

The correlation between gas response-sensitivity and inter-particles spacing properties was studied by Lewis and co-workers (108) by using AuNPs capped with five different straight chain alkanethiols (containing 4-11 carbons in length). They observed an increase in sensitivity to hydrocarbons with the increasing length of the capping agent, yet they reported the opposite tendency for alcohols sensitivity.

Regarding the size of the nanoparticles, in a comparative study on the performance of films comprising AuNPs of either $4 \mathrm{~nm}$ or $9 \mathrm{~nm}$ in diameter, Vossmeyer and co-workers showed that they exhibit similar sensitivities towards vapors.(93) Conversely, Tsoukalas and co-workers compared the performance of hybrid films based on polymers and $5 \mathrm{~nm}$ or $100 \mathrm{~nm}$ AuNPs they observed a higher sensitivity to humidity for $5 \mathrm{~nm}$ AuNPs when using a $5 \mu \mathrm{m}$ electrode gap.(109) Mayer and co-workers compared the performance of 
monolayer and multilayer $15 \mathrm{~nm}$ AuNPs stripes towards humidity (See Figure 9).(86) While the monolayer system showed domains of loosely packed and closely arranged particles, the multilayer films exhibited densely packed structures. These morphological differences led to diverse charge transport regimes. For monolayer AuNPs stripes, single electron charging effects dominate the charge transport, resulting in non-linear I-V characteristics (Figure 9A). On the other hand, for multilayer AuNPs stripes, linear I-V characteristics were observed (Figure 9B), indicating that activated tunnelling dominates the charge transport. Besides, the authors showed how the charge transport mechanism influences the sensitivity of the system for the humidity detection (Figure 9C-D).

A

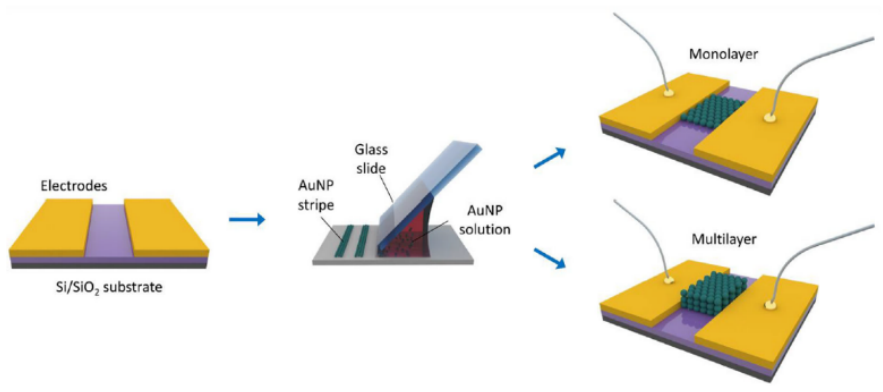

B
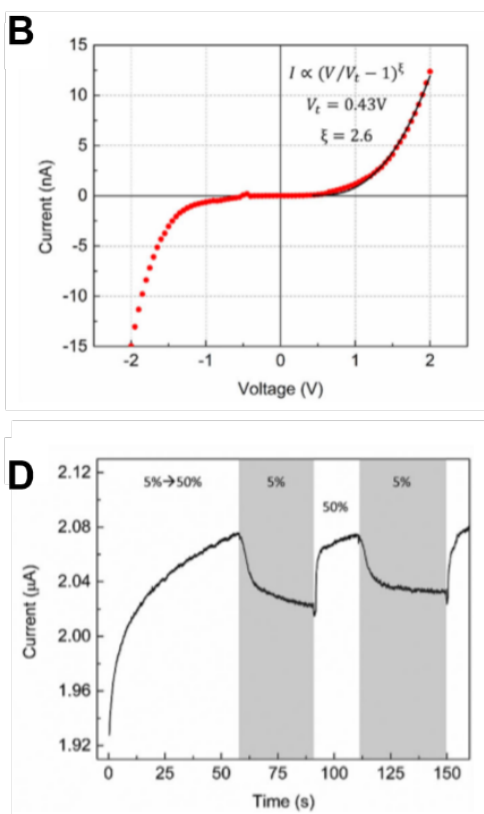

C

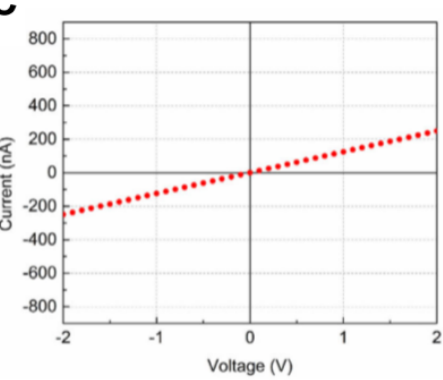

E

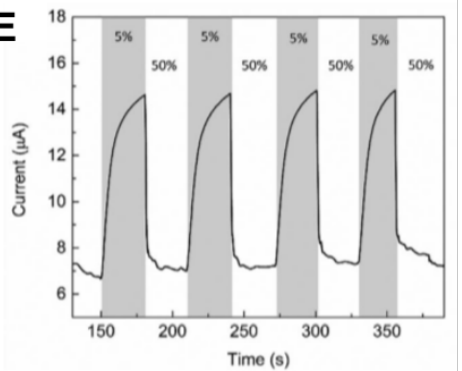

Figure 9. (a) Sketch of the AuNP stripe fabrication process. By controlling the parameter of the convective self-assembly (CSA) process, AuNP stripes composed of mono- or multilayers can be fabricated on the $\mathrm{Si} / \mathrm{SiO} 2$ substrates. (B-C) I-V characteristics of (b) a monolayer AuNP stripe, and (c) a multilayer AuNP stripe. (d-e) The changes in the measured current of a monolayer (d) or a multilayer (e) AuNP stripe sample at a 
constant bias as $\mathrm{RH}$ was switched between 5 and $50 \%$. Adapted from reference (86) with permission from Wiley-VHC.

Another interesting example where the morphology of the film affects not only the sensitivity but also the conduction mechanism through the nanoparticles films was provided by Haick and co-workers.(110) They demonstrated that continuous or perforated films of NPs exhibited different responses against volatile organic compounds (VOCs) and/or humid air (RH). They correlated the different sensitivity with the different conduction mechanism.

In addition to metal NPs and organic molecular linkers, other key parameter to modulate the sensitivity of the whole system would be the device architecture. For example, Tsoukalas and co-workers showed that the distance of the IDA electrodes is inversely proportional to the sensitivity towards vapors.(109) On the other hand, great efforts have been done to achieve practical and universal applicability of these kind of sensors in terms of miniaturization or the use of a flexible architectures. Zellers and co-workers (111) and Willis and co-workers (112) demonstrated that high sensitivity toward vapors may be achieved by using chemosensor arrays with sensing areas down to $0.0025 \mathrm{um}^{2}$.(112) Regarding the use of flexible substrates such as PET, Zhong and co-workers (113-115) and Vossmeyer and co-workers (93) have shown that the electrical characteristics of the nanoparticles films onto flexible substrates depends not only on its exposure to vapor molecules but also on the device strain properties. Although a device strain may not alter the stability of the NPs film it should be considered in order to obtain reliable devices with calibrated response. (115) Haick and co-workers have reported that the presence of humidity can affect the sensitivity of metal NPs chemosensors towards VOCs. (104) They also presented a compensation method that allows to analyse VOCs under variable backgrounds of $2-83 \% \mathrm{RH}$.

Lu and co-workers (116) and Zellers and co-workers (117) studied the sensing performance of a gas chromatographic detector based on metal NPs chemiresistors as a function of temperature and flow rate. Both groups showed that these parameters are vapor-specific and should be optimized in each case. In the case of temperature there is a compromise between two effects; an 
increase in temperature produces an increase in the diffusion rate, due to the easier permeation of gases into the films. However, the increase in kinetic energy also implies that $\mathrm{VOC}$ molecules tend to stay in the gas phase rather than being condensed.

\subsubsection{Pursuing selectivity in gas sensing}

Since the first example of metal NPs-based chemiresistors a great effort has been devoted to improving their performance. During the last decade, apart from gaining a better understanding of the parameters that may influence the sensitivity of these kind of systems also selectivity towards molecules of interest was considered.

Thiol containing molecules has been initially and extensively used as both capping agents and receptors in metal NPs-based chemiresistors due to the huge affinity of thiol groups for the metallic surfaces. $(85,87,118,119)$ Although first chemiresistors responded indistinctively to common VOCs (e.g. acetone, ethanol, toluene), in the next generation of chemiresistors specific selectivity towards a given molecule was also pursued. Some thiol-containing molecules exhibited per se a high selectivity towards specific analytes such as 11-mercapto-1-undecanol towards 1decanol, a biologically relevant odour (87) or mercapto-hexanoic acid towards amines (118). Alongside, one interesting strategy to improve selectivity relies on the use adhoc receptors of the molecule of interest. For instance, Fu and co-workers have used a thiolated molecule decorated with an urea and a tert-butyl motif in order to improve the selectivity of their AuNP-based chemiresistors towards acetone. (85)

In addition to thiol-based ligands, other capping agents have been used as more selective receptors for organic vapors with good accuracy, such as biomolecules,(120) polymers,(109) dendrimers(121, 122) or molecularly imprinted polymers (MIPs).(123)

In this regard, Mandler and co-workers reported the fabrication of a chemiresistor based on a core-shell nanospheres system made of a silver core coated with a MIP (Figure 10).(123) The authors showed the synergetic combination of the sensitivity of AgNPs together with the great selectivity of MIPs. As a model system they have focussed their attention to linalool, a volatile terpene alcohol. The layer of the MIP was thin enough (less than $20 \mathrm{~nm}$ ) to allow current to flow through the NPs film. When the linalool molecules were trapped 
onto the MIP cavities the film resistance revealed an increase being proportional to the linalool concentration.
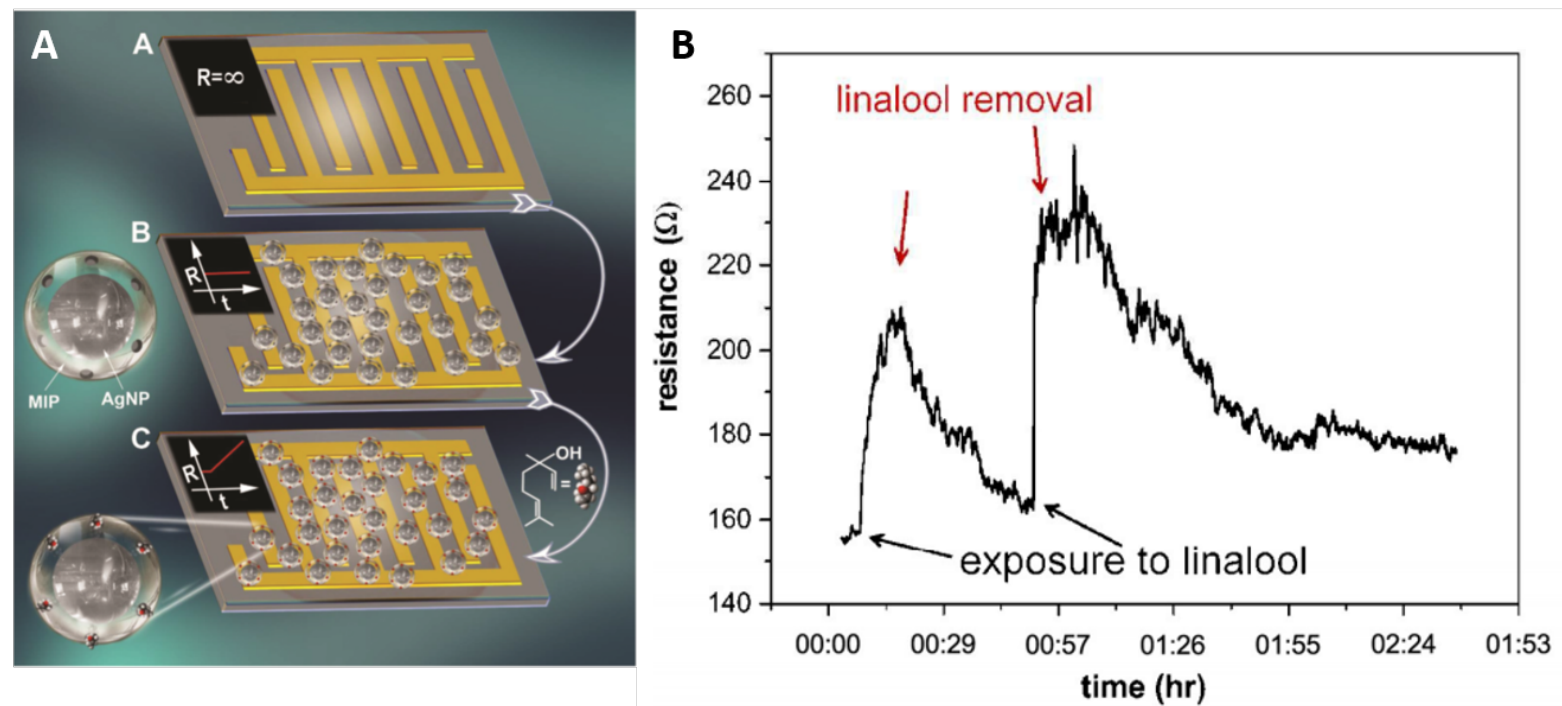

Figure 10. (a)Schematics of the core (AgNPs)-shell (MIP) modified IDA chemiresistor for linalool detection by resistance change measurements. (b) Resistance vs. time measurement, using AgNP@MIPs scattered on PEI modified IDA-CR. Linalool exposure and removal time are marked. Temperature and average humidity were $24.4{ }^{\circ} \mathrm{C}$ and $61 \%$, respectively. Adapted from Ref. (123) with permission of the Royal Society of Chemistry. 


\begin{tabular}{|c|c|c|c|c|}
\hline VOCs & Receptor molecules & Sensitivity & Interferences & Reference \\
\hline Acetone & $\begin{array}{l}\text { 1-(tert-Butyl)-3-((11- } \\
\text { mercaptoundecyl)oxy)urea }\end{array}$ & $\begin{array}{l}\text { LOD: } 10 \\
\text { ppb }\end{array}$ & $\begin{array}{c}\text { Ethanol, benzene, } \\
\text { ethylbenzene and water } \\
\text { vapor }\end{array}$ & $(85)$ \\
\hline 1-decanol & 11-mercapto-1-undecanol & $\begin{array}{l}\text { LOD: } 100 \\
\qquad \mathrm{ppb}\end{array}$ & - & $(87)$ \\
\hline Triethylamine & Mercaptohexanoic acid & $\begin{array}{l}\text { LOD: } 500 \\
\text { ppt }\end{array}$ & $\begin{array}{l}\text { Water, toluene, 1- } \\
\text { propanol, ethanol, } \\
\text { benzylamine, } \\
\text { tripropylamine, } \\
\text { octylamine }\end{array}$ & $(118)$ \\
\hline $\begin{array}{l}\text { Relative } \\
\text { humidity }\end{array}$ & Single-stranded DNA & $\begin{array}{l}\text { 0-100 } \\
\% \text { R.H. }\end{array}$ & $\begin{array}{l}\text { Ethanol, methanol, } \\
\text { hexane, dimethyl } \\
\text { methylphosph-onate, } \\
\text { and toluene }\end{array}$ & $(120)$ \\
\hline $\begin{array}{c}\text { Relative } \\
\text { humidity and } \\
\text { ethanol }\end{array}$ & Poly(2-hydroxyethyl methacrylate) & $\begin{array}{l}\text { LOD: } \\
\text { 2000ppm }\end{array}$ & - & $(124)$ \\
\hline
\end{tabular}


Table 1. Summary of electrical Au/Ag NPs system for volatile organic compounds (VOCs) sensing.

\begin{tabular}{|c|c|c|c|c|}
\hline $\begin{array}{l}\text { Water, etanol } \\
\text { and acetone }\end{array}$ & $\begin{array}{l}\text { Poly(ether-ester) dendrons of } \\
\text { triazole linked mono- and } \\
\text { tri(ethylene glycol)s groups }\end{array}$ & - & - & $(121)$ \\
\hline Linalool & $\begin{array}{l}\text { MIP based on } \\
\text { methyacryloxypropyltrimethoxysilane }\end{array}$ & $\begin{array}{l}\text { LOD: } 223 \\
\text { ppm }\end{array}$ & - & (123) \\
\hline $\begin{array}{l}\text { Relative } \\
\text { humidity }\end{array}$ & Polyvinyl alcohol & $\begin{array}{c}\text { 0-90 } \\
\% \text { R.H. }\end{array}$ & - & (125) \\
\hline $\begin{array}{l}\text { Relative } \\
\text { humidity }\end{array}$ & Dopamine & $\begin{array}{l}20-90 \\
\% \text { R.H. }\end{array}$ & - & $(126)$ \\
\hline $\begin{array}{l}\text { Relative } \\
\text { humidity }\end{array}$ & Tetra ethylene glycol & $\begin{array}{c}5-85 \\
\text { \%R.H. }\end{array}$ & - & (89) \\
\hline
\end{tabular}




\subsubsection{Towards e-nose in gas sensing}

Selectivity is instrumental towards multiplex analyte detection in complex matrices. Although the use of ad-hoc receptors of the analyte of interest has shown good results in terms of selectivity, its operation in complex matrices and/or mixtures of different analytes may decrease the efficiency of the receptors. During the last decade another kind of strategy was explored, which relied on the use of electronic noses. Such approach is based on the mimicry of a human nose which possess several receptors that are not specific to just one molecule. Each receptor generates a different response when interacts with a certain molecule and the combination of all sensor's response allows to generate a fingerprint for that molecule and its proper identification by the human brain. An analogous concept can be applied to metal NPsbased chemiresistors, where arrays of NPs with different functionalities can be integrated into a single device and the combination of their response towards a molecule, together with a statistical analysis, can lead to the proper identification of a wide range of compounds.

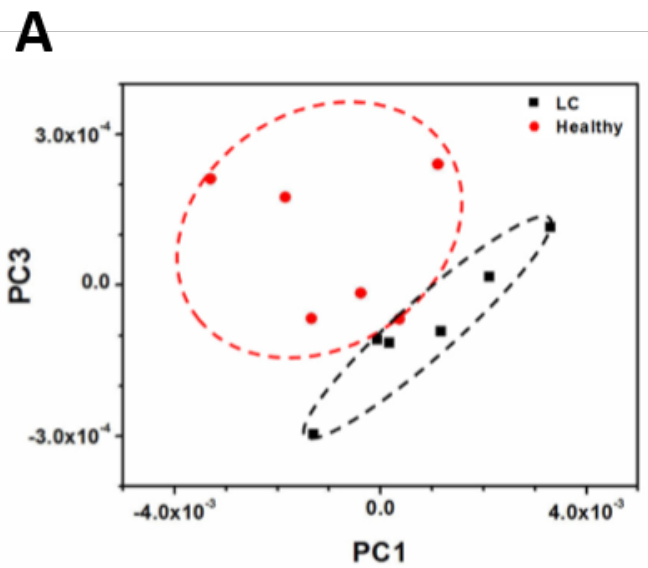

(A)

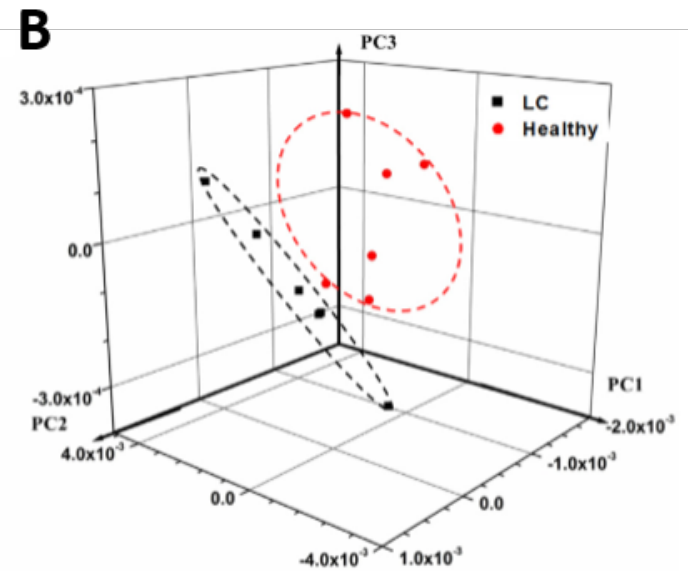

(B)

Figure 11. 2-D (a) and 3-D (b) PCA score plots for sensor responses to breath samples from healthy individuals (red circles) and lung cancer patients (black squares). Adapted from reference $(90)$ with permission of Elsevier.

Metal NPs chemiresistive e-nose approach has been successfully applied for the detection of different VOCs during the last decade.(84, 90, 127-129) The use of various receptors together with statistical analysis have been successfully employed by $\mathrm{Lu}$ and co-workers which were able to differentiate with a $96.1 \%$ of correct classification rate (CCR) 15 VOCs by using arrays of AuNPs and 4 different thiolated 
ligands. (129) Moreover, Zhong and co-workers applied this strategy for breath sensing. $(90,128)$ In 2012 , they fabricated a chemiresistor that was capable of selectively detect acetone, a marker for diabetes, in human breath samples. (128) More recently, they reported a nanostructured chemiresistor that was able to distinguish breath samples from healthy and from lung cancer patients (Figure 11).(90) On the other hand, Willis and co-workers reported the impressive classification, with $99 \%$ accuracy, of 35 different tea aromas by using arrays of only 4 types of organofunctionalized AuNPs together with a linear discriminant analysis (LDA). (84)

\subsubsection{Humidity sensors}

Although metal NPs gas sensing devices have been extensively reported for the detection of volatile organic compounds, there are still few examples of humidity sensing devices. In 2010, Zhang and co-workers reported the use of active materials consisted of films of AuNPs-polyvinyl alcohol (PVA) for the realization of humidity sensors. In such a device, the PVA water-absorbing shell was too thick to let the current flow through the devices and the electrical readout was based on changes in the capacitance of the system, resulting in a poor sensitivity of the devices, exhibiting a change $<2 \mathrm{nF}$ in the range between 0 and $90 \% \mathrm{RH} .(125)$ An example of highly sensitive humidity sensors was reported by Lin and co-workers in 2014.(126) In their work, the authors exploited thick films of AuNPs (4-6 nm diameter) coated with a layer of dopamine (DA) as water-absorbing material and transducer of the amount of absorbed water. Such devices displayed a remarkable decrease of the recorded resistance up to 4 orders of magnitude upon increasing the humidity from 10 to $90 \%$ because of the interaction between water and dopamine generating $\mathrm{OH}^{-}$ions as charge carriers embedded within the films. However, such a process requires time to equilibrate, leading to slow response speed (5 s absorption and $10 \mathrm{~s}$ desorption).(126) Recently, Samorì and co-workers reported a humidity sensor based on 3D networks of AuNPs covalently interconnected by oligoethylene glycol di-thiols (OEG) linkers (Figure 12). This system, upon exposure to moisture, undergoes swelling reducing the tunnelling current passing through the system exhibiting unprecedented high response speed ( 26 ms), short 
recovery time ( $250 \mathrm{~ms})$ in absence of any hysteresis effect and a linear response to humidity changes.(89)

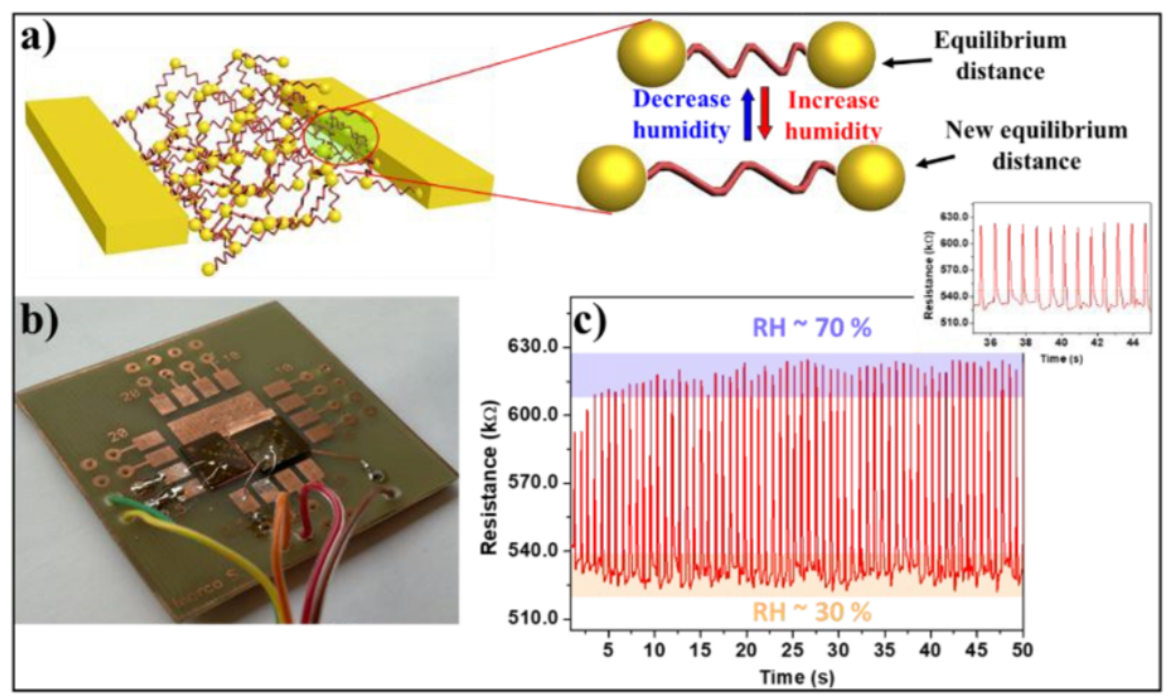

Figure 12. Electrical resistive humidity sensors based on AuNPs-OEG 3D porous networks. (a) Cartoon of the sensing process. (b) Picture of the device setup used for the sensor's characterization. (c) Device's response to short pulses of humid air ( $\mathrm{RH} \sim 70 \%)$ in ambient conditions (constant bias applied $=500 \mathrm{mV}$ ). Inset showing a zoom-in of the plot between 35 and $45 \mathrm{~s}$. Adapted from Ref. (89) with permission of the Royal Society of Chemistry.

\subsection{Chemiresistors operating in liquid media}

By following the same principle of sensing, chemiresistors based on metal NPs films can be also used for the realization of reliable devices operating either in organic or in aqueous phase. In 2007, Raguse, Chow and co-workers reported for the first time the use of chemiresistors for sensing organic molecules in aqueous solutions.(130) They presented a chemiresistor based on a thin film of AuNPs capped with 1-hexanethiol monolayer, which was inkjet printed onto a microelectrode. This sensor combined fast response time $(<3$ $\mathrm{min}$ ), reproducibility and high sensitivity (down to $0.1 \mathrm{ppm}$ range) for toluene, dichloromethane and ethanol molecules dissolved in $1 \mathrm{M} \mathrm{KCl}$ solution.(130)

\subsubsection{Sensitivity enhancement}


The same authors reported later that parameters such as capping agent (131), film morphology and ionic strength of the media (132) should be carefully modulated in order to maximize the sensitivity and selectivity of the AuNPs films to organic molecules in aqueous solutions. Besides, they also investigated the effect on the response time of AuNPs-based chemiresistors as a function of analyte, SAM/water partition coefficient, analyte-water flow speed and film thickness, both theoretically and experimentally. $(133,134)$

The effect of organic solvents is a key parameter that has attracted a great attention when sensing in liquid media since it can be the analyte of interest,(135) or it can influence (or hinder) the sensing of other molecules.(136) For example, Reissner and co-workers studied the sensing of solvents by $2 \mathrm{D}$ monolayers of AuNPs functionalized with 1-dodecanethiol. Immersion of such films in solvents such as ethanol or THF caused an increased interdigitation of the aliphatic chains with a subsequent decrease of the inter-particles distance and, therefore, an increase in the measured current by a factor of 36 (in ethanol) and 22 (in THF). Such a phenomenon is not reversible and it is accompanied by structural changes.(135) More recently, Chow and co-workers reported the modulation of the sensing performance as a function of the presence of organic solvent. They demonstrated, both theoretically and experimentally, that the solvent composition has a strong influence on the partitioning of a molecule across the sensor and the solvent interface.(136)

In order to demonstrate the versatility of this kind of chemiresistors, in 2014 Chow, Raguse and co-workers showed that nanoparticle films are capable of being used as chemically sensitive, active (i.e. transistor-like) components.(137) They described a general method to modulate the sourcedrain resistance of a functionalized metal NP film in an aqueous electrolyte solution, through application of a gate potential in combination with hydrophobic gate ions.

More recently, Zhong and co-workers developed a flexible sweat sensor based on a novel class of nanoparticle-nanofibrous membranes. They have proven its great capabilities for ion detection in solutions with dissolved salts and changes in the relative humidity in the atmosphere.(138) Besides, they 
showed promising potentials for applications of the flexible nanocomposite scaffolds in wearable sweat sensors by detecting changes in sweating and perspiration of individuals before and after exercises.

\subsubsection{Pursuing selectivity when sensing in liquid media}

As for vapor sensors, selectivity has also been a crucial parameter to be controlled when sensing in liquid media. For example, the selectivity of AuNPs functionalized with mixtures of 1-hexanethiol and 4-mercaptophenol was investigated for toluene, hexane, dichloromethane and ethanol in aqueous solution.(139) 1-Hexanethiol-coated AuNPs were selective towards non-polar analytes whereas the selectivity was reduced upon increasing the composition of 4-mercaptophenol on the surface. It was also shown that the selectivity to ethanol could be enhanced 3-fold by using a sensor that was functionalized with a mixture of $60 \%$ 1-hexanethiol and $40 \%$ 4-mercaptophenol compared to a sensor functionalized with pure thiols only.

A
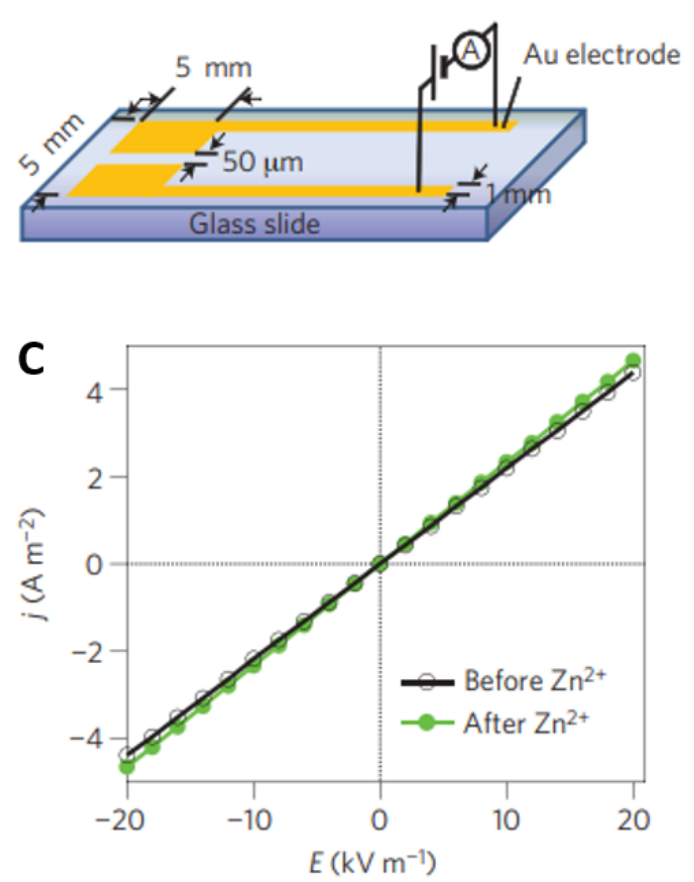

B
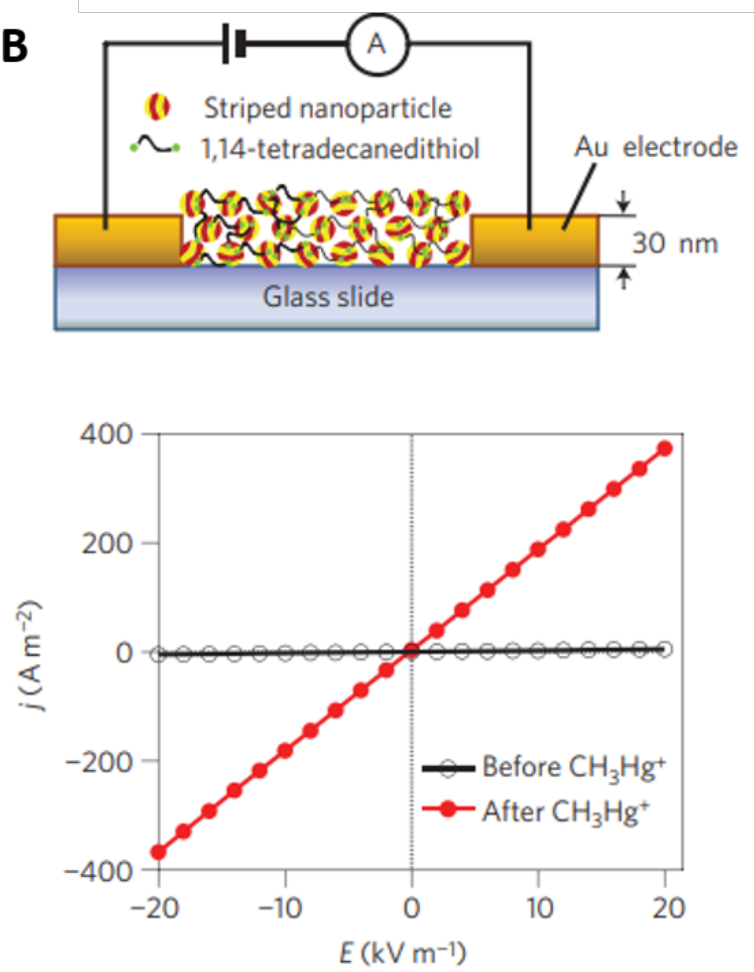

Figure 13. (a-b) Schematic representation of the solid-state sensors consisted of a film of striped-patterned AuNPs. (c) Ohmic current density versus applied field, j-E, and dependencies for a film of striped $\mathrm{HT}_{\mathrm{E}} \mathrm{EG}_{3} \mathrm{Au}$ NPs before exposure to cations (black circles) and after exposure to cations (coloured circles). In the graph on the left, the conductance of 
the films is virtually unchanged after immersion in a $1 \mathrm{mM}$ solution of $\mathrm{Zn}^{2+}$ (green circles). In the graph on the right, immersion of the same film in a $1 \mathrm{mM}$ solution of $\mathrm{CH}_{3} \mathrm{Hg}^{+}$(red circles) results in a marked change in the conductance (note the difference in the j ranges in the two plots). Adapted with permission from reference (140). Copyright 2012 Nature Publishing Group.

Another interesting application of such concepts consists in the fabrication of ion sensing devices. In 2012, Stellacci and co-workers reported that 3D (multi-layered) films of AuNPs were employed for the quantitative and selective detection of toxic $\mathrm{CH}_{3} \mathrm{Hg}^{+}$ions in water with attomolar detection limit.(140) These outstanding sensitivities were achieved by using AuNPs functionalized with a mixture of hexanethiol $(\mathrm{HT})$ and alkanethiols terminated with $n=1,2$ or 3 ethylene glycol (EG) units. This self-assembled monolayer covering the nanoparticles form striped-like domains that generate supramolecular pockets capable of selectively bind the targeted ions. Upon binding event, the tunnelling current through the film changes dramatically. The generation of a percolative path for the charge carriers to travel across the electrodes results in an increased current output, proportional to the number of ions absorbed (Figure 13). The authors showed the universality of the device, the selectivity of the solid-state sensor was tuned by varying the number of ethylene glycol units forming the ligand shell, showing that $H T / E G_{3}$ mixed SAM can detect $\mathrm{CH}_{3} \mathrm{Hg}^{+}$ions with a limit of detection (LOD) of $\approx 1 \mathrm{aM}, \mathrm{HT} / \mathrm{EG}_{2}$ mixed SAM can detect $\mathrm{Cd}^{2+}$ ions down to concentrations of $\approx 1 \mathrm{pM}$, while HT/EG 1 mixed SAM can detect concentrations of $\approx 1 \mathrm{mM}$ of $\mathrm{Zn}^{2+}$ ions.(140)

On the other hand, polar molecular bridges such as peptides can be also used to bind charged analytes such as ions, increasing the conductance of the system.(141, 142) By preparing contact electrodes using a head-to-head pyridine dimer, Nishino and co-workers have shown that the coordination of a single metal ion such as $\mathrm{Zn}^{2+}$ can lead to a facilitated electron transfer in sandwich-type molecular-junctions.(143) Yang and co-workers proposed an ultrasensitive device to detect $\mathrm{Cu}^{2+}$ ions based on a network of core-satellite AuNPs (45 $\mathrm{nm}$ and $13 \mathrm{~nm}$ in diameter respectively) functionalized with Lcysteine.(144) This amino acid can bind copper ions via coordination through its carboxyl and amine groups. The chelation of copper ions forms AuNP/L- 
cysteine/Cu${ }^{2+} / L$-cysteine/AuNP molecular junctions resulting in a significant increase of the tunnelling current across the network. The use of core-satellite AuNPs allowed the authors to produce a reproducible heterogeneity within the film.

The very same hybrid structure could be employed to detect chiral species, by exploiting the favourable interaction between the $L$-cysteine and $D$ carnitine.(145) It was observed that within the nanojunctions, $L / D$-carnitine could interact with the core-L-cysteine functionalized AuNPs, making the nanojunctions highly resistive to the tunnelling current. When $L / D$-carnitine is replaced by copper ions, the nanojunctions become more conductive. The $\mathrm{Cu}^{2+}$ displacement depends on the binding strength of each molecule, and since the interaction between heterochiral molecules ( $L$-cysteine/D-carnitine) is stronger than that between homochiral molecules (L-cysteine/L-carnitine), the rate of displacement within the film after exposure to copper ions can be measured and used to perform chiral recognition. As in other chemiresistors, the change in resistance is amplified due to a large number of tunnelling junctions.

The combination of the sensitivity of NPs-based chemiresistors with the selectivity of antibodies (Ab) would represent an excellent alliance. The simplest way to achieve it would be by fabricating films of NPs interconnected by Abs. Unfortunately, antibodies are conformationally large proteins so the film would be highly resistive due to a very large inter-NPs distance, such that the recognition of the analyte would have little or no impact on the film resistance. To overcome this obstacle, Gooding and co-workers designed a smart displacement assay within the NP film.(146) They have used gold-coated magnetic nanoparticles (Au@MNPs) functionalized with the analyte, enrofloxacin (a veterinarian antibiotic) and subsequently with anti-enrofloxacin IgM antibodies (Ab-Au@MNPs). The use of magnetic nanoparticles allowed the authors to create the NPs film by the magnetically driven assembly, without the need of any alkanedithiol, that is expected to have high resistance, due to the high distance between NPs. If these Ab-Au@MNPs are previously exposed to a solution containing enrofloxacin, a competition of the Ab between the free and the surface-bound enrofloxacin will take place. Therefore, some of the antibodies will detach from the Au@MNPs surface, and when the film is now 
fabricated will give rise to a lower resistance because the smaller distance between NPs (Figure 14).(146)
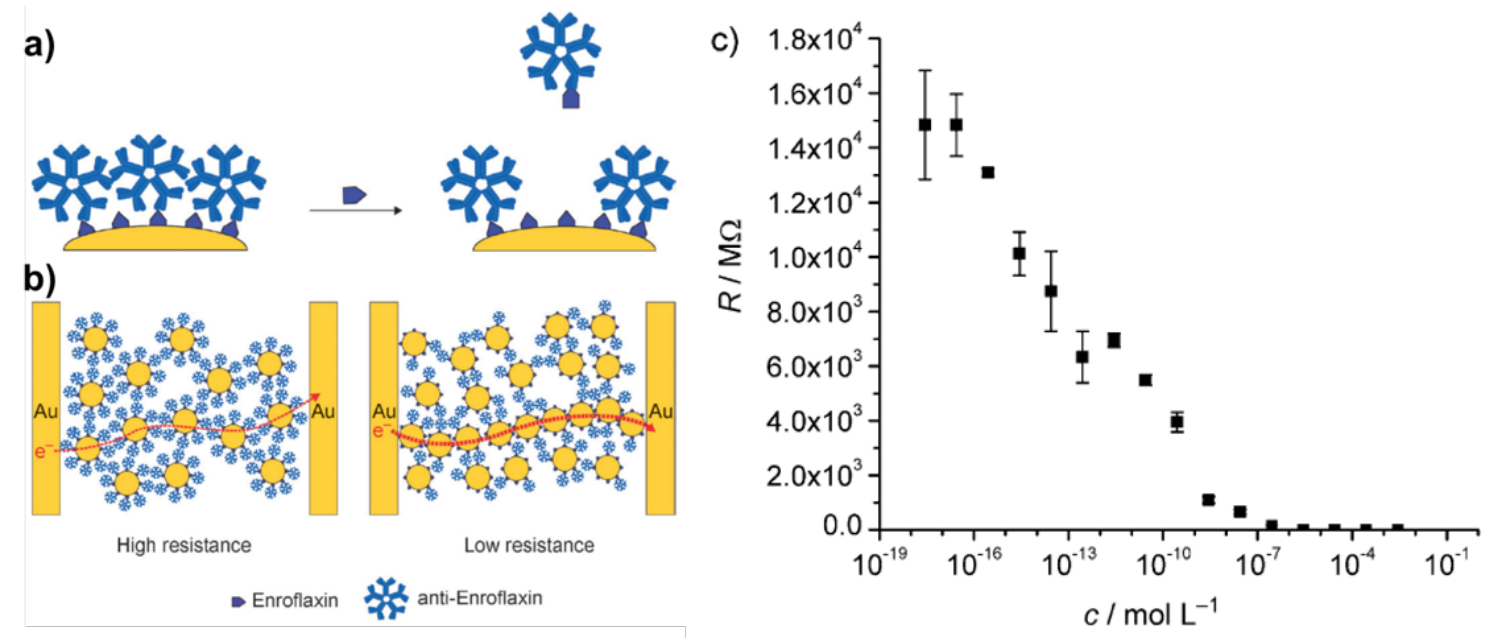

Figure 14. (a) Schematic representation of the Ab-Au@MNPs. When placing into a sample solution that contains enrofloxacin, some of the antibodies dissociate from the Ab-Au@MNPs to bind the solution free enrofloxacin. (b) Representation of the NPs film magnetically assembled consisted of Ab-Au@MNPs between two interdigitated electrodes. Such films have high resistance. After exposure to the solution sample and dissociation of antibodies, some particles in the NPs film can approach each other more closely, decreasing the resistance of the film. (c) Plot of measured resistance versus the concentration of enrofloxacin used. A detection limit of $0.28 \mathrm{fM}$ was seen with this Au@MNP biochemiresistor sensor system. Adapted from reference (146) with permission from Wiley-VHC.

Mulchandani and co-workers reported the highly selective toxic $\mathrm{Cr}^{4+}$ ion detection in drinking water by using a reduced graphene oxide ( $\mathrm{rGO}$ ) chemiresistor and 1,4-dithiothreitol (DTT) functionalized AuNPs.(147) The detection strategy is based on the selective binding between DTT functionalized AuNP $\mathrm{s}_{\mathrm{s}}$ located in rGO conductive channels and DTT functionalized $A_{u N P}$ in solution through the formation of disulfides induced by $\mathrm{Cr}^{4+}$ at acidic condition, which results in complexation of DTT functionalized $A_{u N P}$ on the $\mathrm{rGO}$ channels producing a readily measurable resistance change.

AuNPs are therefore the most popular scaffolds which are highly suitable for being integrated in chemiresistor for sensing in liquid media. Surprisingly, to the best of our knowledge, only one work can be found in the literature on the integration of AgNPs in chemiresistor for sensing compounds in liquid media. 
Such work was recently published by $\mathrm{Ho}$ and co-workers by describing a new AgNPs microfluidic paper-based analytical device (Ag- $\mu P A D)$ chemiresistor for nitrite ions detection in environmental analysis. They used AgNPs to create an ink by photonic sintering and then they functionalized it with naphthylenediamine (NED) which acts as a receptor molecule. Sensing of nitrite ions is based on traditional a Griess reaction where in the presence of sulphanilamide(SA) there is a coupling reaction of the diazonium ion and the diamine to form an azo product and hence an increase in the resistance of the film is triggered.(148)

The chemical sensing field would benefit of more sensitive readouts, and in this line, a promising approach has been recently reported by Grzybowski and co-workers.(149) The authors have created chemoelectronic circuits using ligand-stabilized AuNPs, which act as building blocks for both: analyte sensing and information processing. Such result was obtained by establishing the basic parameters that control the characteristics of AuNP-based diodes, and also, showing that the sensibility can be tune by varying the organic ligands that constituted the NP-stabilizing monolayer. 


\begin{tabular}{|c|c|c|c|c|}
\hline Analyte(s) & Receptor molecules & Sensitivity & Interferences & Reference \\
\hline $\begin{array}{c}\mathrm{CH}_{3} \mathrm{Hg}^{+}, \mathrm{Cd}^{2+}, \mathrm{or} \\
\mathrm{Zn}^{2+}\end{array}$ & $\begin{array}{c}\text { Mixtures of hexanethiol and } \\
\text { alkanethiols terminated with } \\
n=1,2 \text {, ot } 3 \text { ethylene glicol units }\end{array}$ & $\begin{array}{l}\text { LOD: } 1 \mathrm{aM}, \\
\text { 1pM or } \\
1 \mathrm{mM}\end{array}$ & $\begin{array}{c}\mathrm{Zn}^{2+}, \mathrm{K}^{+}, \mathrm{Na}^{+}, \mathrm{Cd}^{2+}, \mathrm{Ti}^{+} \\
\mathrm{Ca}^{2+}, \mathrm{Cu}^{2+}, \mathrm{Ni}^{2+}, \mathrm{Co}^{2+} \\
\mathrm{Pb}^{2+}, \mathrm{Ag}^{+}, \mathrm{CH}_{3} \mathrm{Zn}^{+}, \mathrm{Hg}^{2+} \\
\mathrm{Cs}^{+}, \mathrm{CH}_{3} \mathrm{Hg}^{+}, \mathrm{Cs}^{+}\end{array}$ & $(140)$ \\
\hline $\mathrm{Zn}^{2+}$ & 4-mercaptopyridine & $\begin{array}{l}\text { LOD: } 50 \mu \\
\qquad \mathrm{M}\end{array}$ & $\mathrm{Co}^{2+}, \mathrm{Mn}^{2+}, \mathrm{Na}^{+}$ & $(143)$ \\
\hline $\mathrm{Cu}^{2+}$ & L-cysteine & $\begin{array}{c}\text { LOD: } 210^{-} \\
{ }^{16} \mathrm{M}\end{array}$ & $\begin{array}{c}\mathrm{Co}^{2+}, \mathrm{Cd}^{2+}, \mathrm{Zn}^{2+}, \mathrm{Ca}^{2+} \\
\mathrm{Cu}^{2+}, \mathrm{Fe}^{2+}, \mathrm{K}^{+}, \mathrm{Mg}^{2+} \\
\mathrm{Mn}^{2+}, \mathrm{Na}^{+}, \mathrm{Ni}^{2+}, \mathrm{Pb}^{2+}\end{array}$ & $(144)$ \\
\hline $\mathrm{Cr}^{6+}$ & 1,4-dithiothreitol & $\begin{array}{l}\text { LOD: } 0.9 \\
\text { nM }\end{array}$ & $\begin{array}{c}\mathrm{Na}^{+}, \mathrm{K}^{+}, \mathrm{Ca}^{2+}, \mathrm{Pb}^{2+}, \mathrm{Zn}^{2+} \\
\mathrm{Ni}^{2+}, \mathrm{Cr}^{3+}, \mathrm{Fe}^{3+}, \mathrm{Al}^{3+} \\
\mathrm{Mn}^{2+}, \mathrm{Hg}^{2+}\end{array}$ & $(147)$ \\
\hline $\mathrm{NO}_{2}^{-}$ & $\begin{array}{c}\text { Sulphanilamide and } \\
\text { naphthylethylenediamine }\end{array}$ & $\begin{array}{l}\text { LOD: } 8.5 \\
10^{-11} \mathrm{M} \text {, } \\
\text { Linear } \\
\text { ranges: } 1.0 \\
10^{-8} \mathrm{M} \text { to }\end{array}$ & $\begin{array}{c}\mathrm{H}^{+}, \mathrm{Na}^{+}, \mathrm{K}^{+}, \mathrm{Ca}^{2+}, \mathrm{NH}_{4}^{+} \\
\mathrm{F}^{-}, \mathrm{Cl}^{-}, \mathrm{Br}^{-}, \mathrm{BrO}_{3}^{-}, \mathrm{IO}_{3}{ }^{-} \\
\mathrm{NO}_{3}{ }^{-}, \mathrm{SO}_{3}{ }^{2-}, \mathrm{SO}_{4}{ }^{2-} \\
\mathrm{ClO}_{4}^{-}, \mathrm{C}_{2} \mathrm{O}_{4}{ }^{2-}\end{array}$ & $(148)$ \\
\hline
\end{tabular}


Table 2. Summary of electrical Au/Ag NPs system for ions, small molecules and biomolecules sensing

$$
\begin{array}{ll}
5.010^{-6} \mathrm{M} & \mathrm{CH}_{3} \mathrm{COO}^{-}, \mathrm{H}_{2} \mathrm{PO}_{4}^{-}, \\
\text {and } 1.0 & \text { glucose, and EDTA } \\
10^{-5} \mathrm{M} \text { to } & \\
3.210^{-3} \mathrm{M} &
\end{array}
$$

Toluene,

hexane, Mixtures of 1-hexanethiol and 4-

dichloromethane mercaptophenol

and ethanol

L and D-

carnitine

L-cysteine and $\mathrm{Cu}^{2+}$

LOD: $10^{-14}$

$\mathrm{M}$

LOD: 0.28

Enrofloxacin

(antibiotic)

Anti- Enrofloxacin

fM, Linear

range: 2.8

$\mu \mathrm{M}-0.28$

$\mathrm{fM}$ 


\subsubsection{Towards e-tongue sensing in liquid media}

Analogously to e-noses, during the last decade mixed SAMs of different thiols on AuNPs surface have been used to fabricate "electronic-tongue" (150) sensor arrays just by changing the ratios between the different components in the monolayer mixture. Following this principle, and by using discriminant analysis Cooper and co-workers were able to distinguish between four simple alcohols dissolved in water.(151) Besides, this kind of sensor arrays was also used to discriminate between complex mixtures of organic molecules dissolved in water and/or seawater. $(126,151)$

Constantino and co-workers reported the synergetic combination of an impedimetric electronic tongue together with surface-enhanced resonance Raman scattering (SERRS) detection in a single sensor.(92) The authors reported the fabrication of LbL films of phospholipids as biological membrane mimetic systems: cardiolipin (CLP) or dipalmitoyl phosphatidyl glycerol (DPPG) and/or AgNPs. This etongue system was able to detect the phenothiazine methylene blue (MB) exhibited sensibility below nanomolar concentrations by both characterization techniques.

In the last few years, chemiresistors have been also employed for healthcare diagnostics. $(152,153)$ It is well demonstrated that when bacteria grow, they produce low molecular weight (MW) VOCs which are potential indicators of bacterial infection. In 2015, Raguse and co-workers demonstrated for the first time that a chemiresistor based on AuNPs is able to discriminate bacterial species based on metabolic changes in liquid cultures. When the released metabolites enter in the thiol functionalized AuNPs film they cause a swell of the film and hence an increase in resistance. The profile of six AuNPs chemiresistors functionalized with different alkanethiols was analysed after its exposure to the bacterial metabolites allowing the detection and discrimination of four different bacterial species.(153)

In 2015, Hubble and co-workers used an automated liquid handling workstation to fabricate AuNP film arrays functionalizing with 132 commercially available organothiol compounds.(154) By using this method, they were able to discriminate and quantify benzene, toluene, ethylbenzene, p-xylene, and 
naphthalene (BTEXN) mixtures in water at low microgram per litre concentration levels by using a high-throughput screening system incorporating a flow injection analysis (FIA) unit.

More recently, García-Cabezón and co-workers reported an impedimetric electronic tongue that was able to discriminate different red wines.(155) This multisensor system is formed by one PEDOT:PSS sensor and two nanocomposites formed by layers of PEDOT:PSS and gold nanoparticles (PEDOT:PSS/AuNP) or layers of PEDOT:PSS and lutetium bisphthalocyanine (PEDOT:PSS/LuPc2). Not only AuNPs and LuPc2 improved the electrocatalytic properties of the layered nanocomposites but also, together with PCA analysis this e-tongue system, they were able to discriminate five red wines with very similar characteristics.

\section{Optical properties}

This section aims to provide a general understanding of the world of plasmonic properties of metal nano-objects, with a special focus on how such phenomena can be exploited for the realization of chemical sensing devices.

The optical properties of metal NPs are a consequence of the interaction between light and the collective oscillation of free electrons on the particle's surface, also known as plasmonic phenomenon. (156) If the metal clusters are smaller than $\sim 2 \mathrm{~nm}$ the Kubo gap is too big and the particles exhibit insulating behaviour. In other words, the electrons are not free to move on the cluster's surface, preventing the existence of surface plasmons and, therefore, of any optical property. On the other hand, if the particles are too big (diameter $>10^{4}$ A) they will behave as a bulk material, exhibiting not localized surface plasmons and the typical high optical reflectivity of metal bulks. For this reason, the term "plasmonic nanoparticle" is meant to include just nano-objects featuring a size between $\sim 2 \mathrm{~nm}$ and $\sim 100 \mathrm{~nm}$.

Surface Plasmons are waves that propagate along the surface of a conductor, usually a metal. These are essentially light waves that are trapped 
on the surface because of their interaction with the free electrons of the conductor.(157) Typically, there are two different SPR modes: I) propagating surface plasmon (PSP) at the flat dielectric-metal interfaces; and II) localized surface plasmon (LSP, see Figure 15) when the plasmons are highly confined in the surface of the colloidal nanoparticles or other nanostructures (e.g. two dimensional nanostructured assemblies). As for the purpose of the present review we will focus only on the LSP of metal NPs.

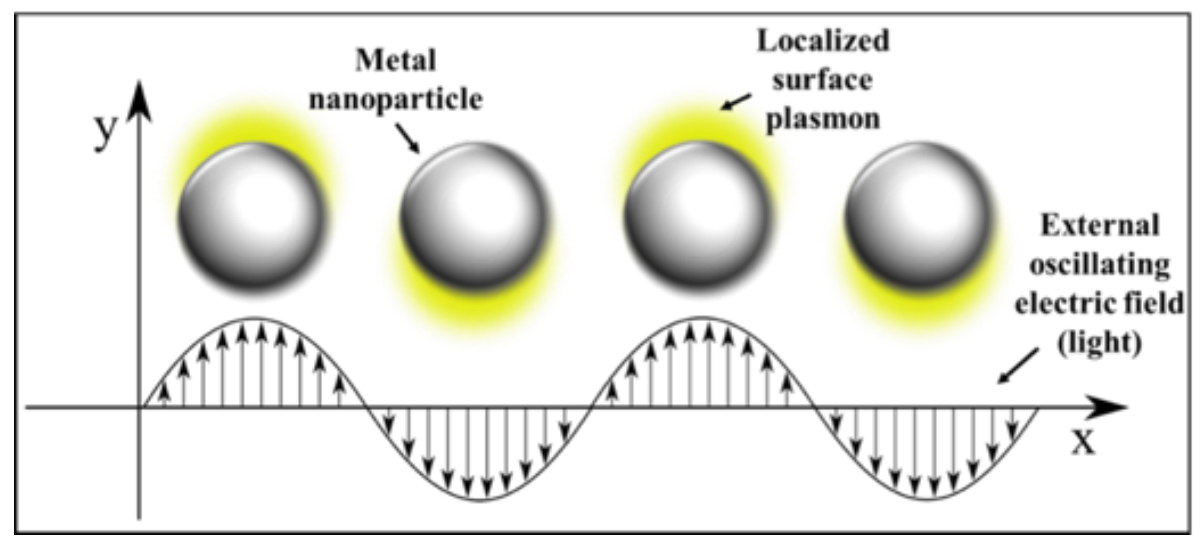

Figure 15. Schematic representation of the formation of Localized Surface Plasmons (LSPs).

The optical properties of bulk materials are characterized by their dielectric functions, $\varepsilon_{m}(\lambda)$, which describe the material's response to an applied electric field as a function of the field's wavelength $(\lambda)$. As a general rule, $\varepsilon_{m}(\lambda)$ is a positive real number, however for non-transparent materials the dielectric function will be a complex number. Metals are included in the list of materials for which $\varepsilon_{m}(\lambda)$ is complex and can thus be expressed as:

$$
\varepsilon_{m}(\lambda)=\varepsilon_{1}(\lambda)+i \varepsilon_{2}(\lambda)
$$

Being $\varepsilon_{1}(\lambda)$ the real and $i \varepsilon_{2}(\lambda)$ the imaginary part of the dielectric function.

When an incident electromagnetic field (i.e. light) interacts with metal nanoparticles, it is enhanced near to the surface of the metal nanoparticles (e.g. near field enhancement) and its exact magnitude can be determined by solving Maxwell's equations. However, it is not always trivial and some approximations are needed, so one useful approximation scheme that has been widely used in the literature is the socalled electrostatic approximation.(158) This approximation is commonly employed in the study of the optical properties of NPs because it works well when the dimensions 
of the irradiated object are much smaller (at least one or two orders of magnitude) than the wavelength of the incident field. Under this condition it can be proved that, the incident electric field induces the oscillation of the free electrons at the metal surface creating an electric dipole p proportional to:

$$
p \propto \frac{\varepsilon_{m}(\lambda)-\varepsilon_{d}}{\varepsilon_{m}(\lambda)+2 \varepsilon_{d}}
$$

Where $\varepsilon_{d}$ is the dielectric function of the surrounding medium.

The largest value of $p$ is achieved when $\varepsilon_{m}(\lambda)=-2 \varepsilon_{d}$ (resonance condition). In the case of metals, as $\varepsilon_{m}(\lambda)$ is a complex function, the magnitude of $p$ will only be limited by $i \varepsilon_{2}(\lambda)$. As long as $\varepsilon_{1}(\lambda)=-2 \varepsilon_{d}$, the smaller $i \varepsilon_{2}(\lambda)$, the stronger will be the p.

The LSPs on the particle's surface oscillate at a certain frequency and can resonate with light leading to an optical extinction spectrum that has a maximum corresponding to the LSPR frequency, which, for the noble metals copper, silver, and gold, occurs in the visible and near-infrared range of the electromagnetic spectrum.(159) The extinction cross-section given by LSPR in metal nanoparticles was described for the first time in details by Mie in 1908 as a combination of absorption and scattering: $(160,161)$

$$
C_{a b s}=C_{e x t}-C_{s c a}
$$

$C_{\text {ext }}$ and $C_{\text {sca }}$ can be calculated as:

$$
\begin{gathered}
C_{e x t}=18 \pi \frac{V}{\lambda} \varepsilon_{d}^{3 / 2} \frac{\varepsilon_{2}}{\left(\varepsilon_{1}+2 \varepsilon_{d}\right)^{2}+\varepsilon_{2}{ }^{2}} \\
C_{s c a}=144 \pi^{4} \frac{V^{2}}{\lambda^{4}} \varepsilon_{d}^{2} \frac{\left(\varepsilon_{1}-\varepsilon_{d}\right)^{2}+\varepsilon_{2}{ }^{2}}{\left(\varepsilon_{1}+2 \varepsilon_{d}\right)^{2}+\varepsilon_{2}{ }^{2}}
\end{gathered}
$$

Where $\mathrm{V}$ is the volume of a NP.

The one reported above is a simplified version of the Mie model that considers just the dipolar contributions inside the particles, considering as negligible all the superior orders. Such approximation is valid just for small spherical particles featuring a diameter $<20 \mathrm{~nm}$. From this model, it implies that 
the nanoparticles' size, shape, surface coating, and dielectric environments as well as the interaction between nanoparticles and other chemical entities can influence the oscillations and, therefore, these events can be transformed into the LSPR spectral change.(162)

\subsection{Optical sensors}

This extraordinary plasmonic phenomenon have given rise to a rapidly developing field of optical nanosensors, where the introduction of target analytes or ions can induce the LSPR shift of plasmonic nanoparticles (in solution or deposited into a solid platform) and may be accompanied by a visual colour change. (163-165)

In the initial optical plasmonic sensors the sensibility of the LSPR to changes in the dielectric environment (refractive index sensors) and to the interaction with other chemical entities (molecular sensors) was exploited. In these cases the colloidal stability is not compromised, and hence minor visual colour changes are expected. The simplest and more immediate way to exploit LSPR-active particles is to detect changes in the bulk refractive index of their environment through the shift in the LSPR wavelength band. Such measurements are typically performed by acquiring UV-Vis extinction spectra on dense nanoparticle films immobilized on a transparent substrate. As expected from the Drude model and from the more precise Mie approximation reported above, by changing the medium e.g. the solvent in which the metal NPs films are immersed, the LSPR peak wavelength shift linearly with the bulk refractive index of the medium. (166-168) For example, Akamatsu and coworkers reported the fabrication of a sensor based on gold nanoparticles core-satellite nanostructures immobilized on glass substrates. They explored their optical properties and demonstrated its high sensing capabilities towards vapor and changes in the refractive index of the medium. (167) The use of metal nanostructure to detect changes in the bulk refractive index is extremely straightforward but does not fully exploit the potential given by the strong confinement of the near field surrounding the nanoparticles. Indeed, since the evanescent near field of the LSPR decays completely within a few nanometers, such systems are extremely powerful to probe nanoscale regions around the 
particles. The highly localized sensing volume allows observing molecular interactions near the particle's surface as a result of the modification in the local refractive index.(163) During the last decade, metal nanoparticles have become one of the most exploited scaffolds for the realization of (bio)chemical sensors. In particular, such an approach has been successfully applied for the direct detection and quantification of serum albumin,(169) antibodies,(170, 171) insulin(172), hormones(173), amino acids(174) and even explosives.(175)

Another interesting application for the LSPR of metal nanoparticles consists of the so-called "colorimetric sensing" where detection of specific analytes triggers a huge visual colour changes. Chen and co-workers (176) recently classified plasmonic colorimetric sensors according to four categories: I) aggregationbased sensors, II) etching-, III) growth-, and IV) nanozyme-based sensors.

I) The most widely used sensing strategy is aggregation-based sensor which relies on the great LSPR wavelength shift due to the Localized Surface Plasmon coupling caused by the aggregation of NPs in solution. In the presence of the proper analyte the assembly of the NPs can be triggered by i) the complexation between the analyte and the capping agents of the NPs, or by ii) the change of capping agent length or structure on the metal NPs surface and hence producing the destabilization of the NPs. Both processes cause a strong and evident change of colour from red to blue (AuNPs) or from yellow to red (AgNPs). Alternatively, any binding event that breaks down a NP conglomerate or that avoids the assembly formation can be also a target analyte because in this particular case the visual colour change is the opposite as mentioned above. By mastering this approach it is possible to achieve limit of detection down to the nanomolar (Figure 16). (177) One of the greatest advantages of such approach is that the detection process can be performed just by mixing the NPs with complex matrices of different analytes in solution because if smartly engineered, capping agents can form complexes in a very selective way with the molecule of interest. The colour change can be visually detected by the naked eye and neither expensive nor electrically powered sophisticated instrumentations are required. 


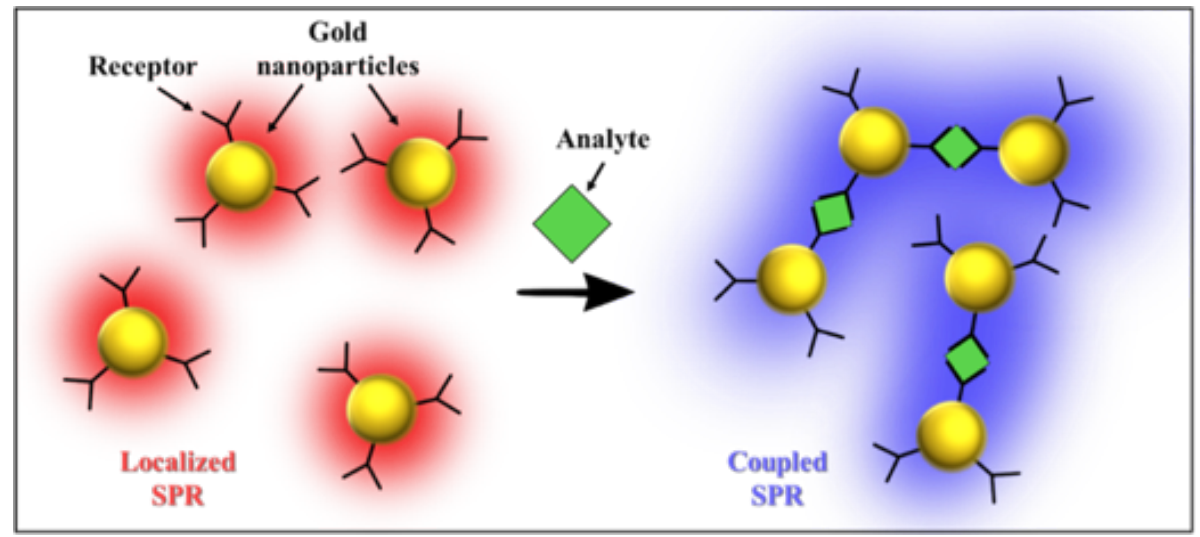

Figure 16. Schematic representation of the working principle of colorimetric chemical sensors based on the Localized Surface Plasmon Resonance of AuNPs.

Differently, Samorì and co-workers reported a straightforward approach for the fabrication of a colorimetric humidity sensor based on $2 \mathrm{D}$ networks of gold nanoparticles, interconnected with hygroscopic organic linkers.(165) In the presence of humidity the hygroscopic network swells, thereby increasing the interparticle distance. By controlling the humidity level, it was possible to tune the interparticle distance to reversibly trigger plasmon coupling collectively over several millimeters.

II) Generally speaking, an etching colorimetric sensor is based on monitoring a colour modification due to the change in shape or in size of nanomaterials after their exposure to an analyte containing solution. This strategy has been extensively applied for Au nanorods(178) but also for $A u$ nanospheres.(179) A nice approach employing Au@Ag core@shell NPs in combination with dithiothreitol (DTT) has been develop for the detection of $\mathrm{Hg}^{2+}$ ions. (179) DTT molecules first absorb onto the surfaces of Ag shells via sulphur atoms to initiate silver sulfidation and loss their thiol proton; on the other hand, the thiol-adsorbed silver was oxidized to $\mathrm{Ag}^{+}$by $\mathrm{O}_{2}$ gas (from the air) with the assistance of $\mathrm{H}^{+}$. Therefore, in the absence of $\mathrm{Hg}^{2+}$ ions, DTT promotes the etching of the $\mathrm{Ag}$ shell, but when $\mathrm{Hg}^{2+}$ ions are present they form complexes with DTT and hence avoid the silver etching.

III) The growth colorimetric sensors are based on the influence of the target analyte into the NPs growth either by interacting with the NPs or the reducing agent. The presence of the analyte during the NPs growth will 
determine its final size, shape and hence its optical properties. This strategy has been used for the sensing of metal ions,(180) small molecules,(181) proteins and DNA.(182)

Although this Review focuses on nanospheres, the outstanding research endeavour by Stevens and co-workers using nanostars is worth being highlighted.(183) Such work relies on the use of Au nanostars as nanosensor, and by controlling the crystal growth kinetics of $\mathrm{Ag}$ coating onto these $\mathrm{Au}$ nanostars promoted by an enzyme (glucose oxidase, GOx) the authors are capable to modify the plasmonics of the system generating a measurable signal. Interestingly, such experiment displayed the phenomenon of inverse sensitivity by which the signal obtained is larger when the target molecule is less concentrated, being possible because of the signal-generation mechanism (Figure 17).
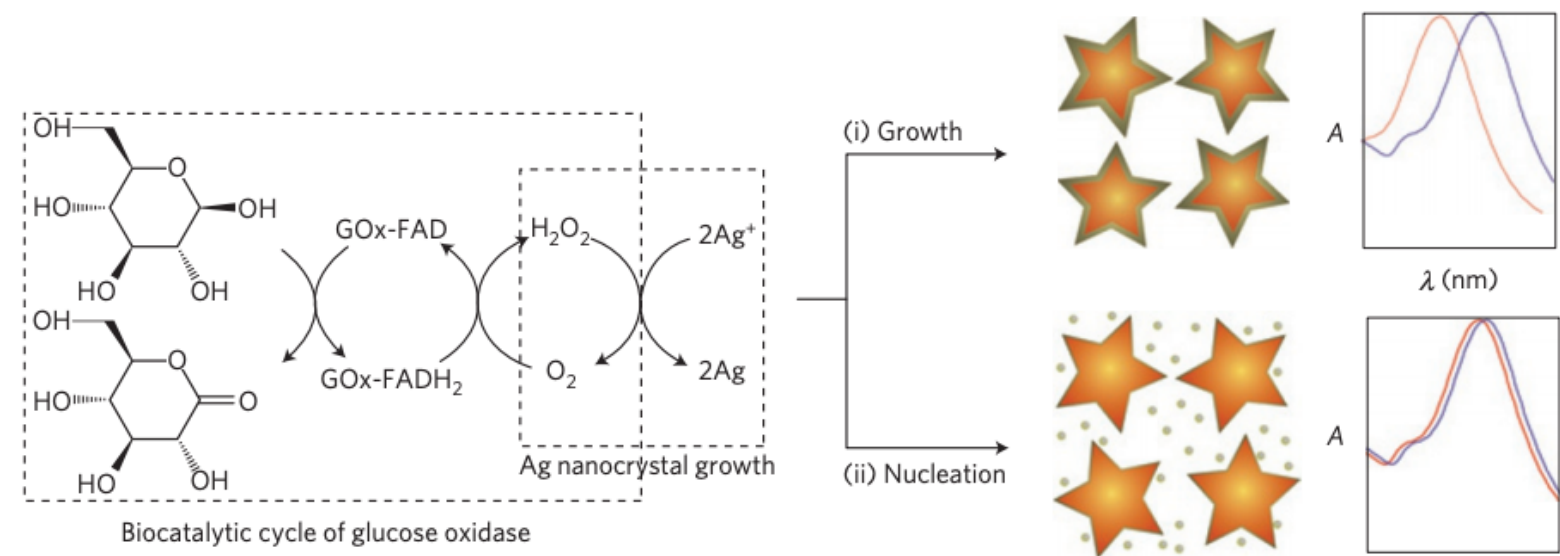

$\lambda(\mathrm{nm})$
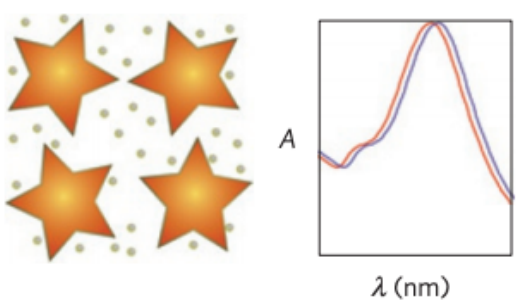

Figure 17. Scheme of the proposed signal-generation mechanism by means of enzymeguided crystal growth. GOx generates $\mathrm{H}_{2} \mathrm{O}_{2}$, which reduces $\mathrm{Ag}^{+}$ions to grow a silver coating around plasmonic nanosensors (gold nanostars); (i) at low concentrations of GOx the nucleation rate is slow, which favours the growth of a conformal silver coating that induces a large blueshift in the LSPR of the nanosensors; (II) when GOx is present at high concentrations, the fast crystal growth conditions stimulate the nucleation of silver nanocrystals and less silver is deposit on the nanosensors, therefore generating a smaller variation of the LSPR. Adapted with permission from reference (183) Copyright 2012 Nature Publishing Group. 
IV) A more recent kind of plasmonic colorimetric biosensor is based on the lately discovered enzyme-mimetic activity of AuNPs. AuNPs possess peroxide-like activity because they can catalyse the oxidation of a chromophore $\left(3,3^{\prime}, 5,5^{\prime}\right.$-tetramethylbenzidine, TMB) in the presence of $\mathrm{H}_{2} \mathrm{O}_{2}$.(184) This enzyme-like behaviour is enhanced in the presence of $\mathrm{Hg}^{2+}$ ions due to the formation of Au-Hg amalgam on the AuNPs surface. Therefore, this system can be used to detect $\mathrm{Hg}^{2+}$ ions with high specificity.

Compared with natural enzymes, artificial AuNP enzymes have several advantages, such as high stability against denaturing, easy synthesis, and facile storage. AuNPs with different surface modifications have not only peroxidaselike activity but also glucose oxidase,(185) superoxidase dismutase(186) and catalase-like activity.(187)

\subsubsection{Colorimetric ion sensors}

All of the above-mentioned characteristics made metal NPs sensor particularly appealing for the in-situ detection of toxic metal ions in water samples. One of the first examples in this field was reported by Chen and coworkers with the selective detection of micromolar concentration of $\mathrm{K}^{+}$ions in complex matrices including $\mathrm{Li}^{+}, \mathrm{Cs}^{+}, \mathrm{NH}_{4}{ }^{+}, \mathrm{Mg}^{2+}, \mathrm{Ca}^{2+}$ and excess of $\mathrm{Na}^{+}$using AuNPs functionalized with 15-crown-5 moieties.(188)

For heavy metals, which pose significant public health hazards, the tolerated concentrations of their cations in water are significantly lower and the systems must be properly engineered to meet the requirements. In 2009, Ray and co-workers developed a colorimetric sensor to detect the presence of $\mathrm{As}^{3+}$ ions in groundwater with a detection limit of $5 \mathrm{ppb}$ by using glutathione, dithiothreitol, and cysteine, exploiting the strong affinity of the targeted ions with sulphur-containing groups.(189) This sensitivity was improved in 2014 by Zhou and co-workers reaching a detection limit of $1.26 \mathrm{ppb}$ using ad-hoc aptamers to induce the aggregation of AuNPs in the presence of $\mathrm{As}^{3+}$.(190) 
Along this line, Chen and co-workers reported a colorimetric detection system able to perform mercury speciation analysis.(191) They used two main components to develop the sensing system: citrate-stabilized AuNPs and the ligand diethyldithiocarbamate (DDTC) which form a stable complex with $\mathrm{Cu}^{2+}$ ions. In the presence of mercury ions, they replaced the copper ions from the DDTC complex-forming new $\mathrm{Hg}$-DDTC complexes that have free sulfur atoms. These sulfur atoms can replace the citrate molecules from the surface of the AuNPs leading to the NPs aggregation. The additional use of ethylenediaminetetraacetic acid (EDTA) as masking agent permitted the detection of three organic mercury species (methyl, ethyl and phenyl mercury) in the presence of inorganic $\mathrm{Hg}^{2+}$ ions. More recently, Liu and co-workers achieved a picomolar sensitivity in $\mathrm{Hg}^{2+}$ ions detection by using oligonucleotides modified AuNPs.(192) These A NPs were fixed on a glass slide and can bound to free AuNPs in the solution in the presence of $\mathrm{Hg}^{2+}$ because of oligonucleotide hybridization. The hybridation of DNA strands is mediated by the presence of $\mathrm{Hg}^{2+}$ ions and followed by using dark-field microscopy (Figure 18).

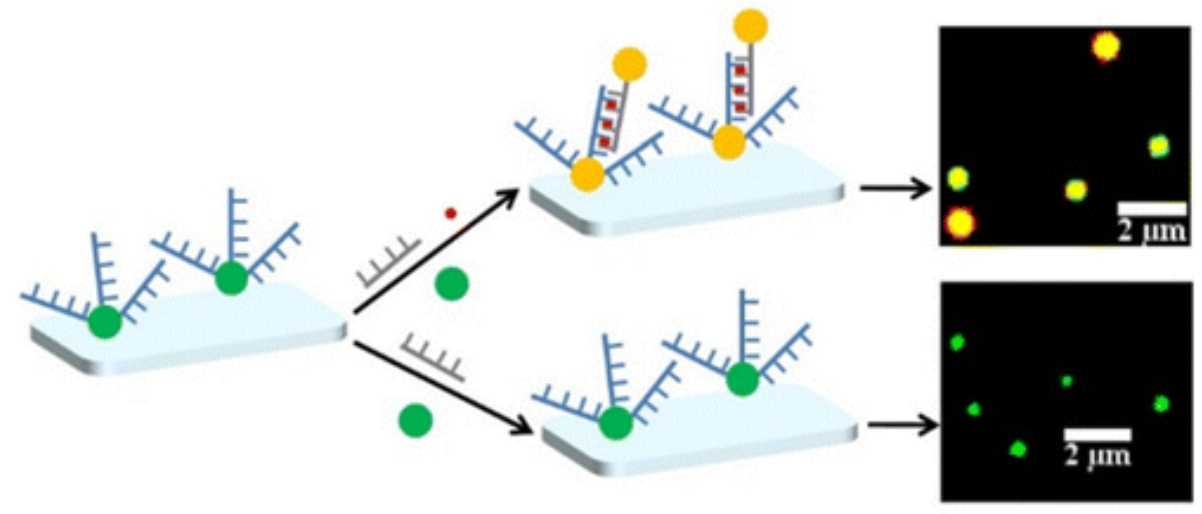

Figure 18. Scheme of $\mathrm{Hg}^{2+}$ sensor at the single-particle level with darkfield microscopy. Adapted with permission from reference (192). Copyright 2016 American Chemical Society.

A different sensing strategy of $\mathrm{Hg}^{2+}$ ions where picomolar sensitivity is also achieved was developed by Chakraborty and co-workers.(193) In this work the authors synthesized AgNP functionalized with different mercaptobenzoheterocyclic compounds. $\mathrm{Hg}^{2+}$ ions have a double role: i) it can interact with thiol-derivated ligands triggering its detachment of the metallic surface and hence leaving patches of exposed surface of silver; and ii) it can undergo a redox reaction involving $\mathrm{Ag}(0)$ and $\mathrm{Hg}^{2+}$ which leads to formation of 
a Ag-Hg nanoally. Both together these mechanisms lead to the nanoparticles aggregation.

During the last decade many similar approaches have been reported for the detection of not only $\mathrm{Hg}^{2+}$,(194) but also other cations (see Table 3 ) such as $\mathrm{K}^{+}, \mathrm{As}^{3+}, \mathrm{Pb}^{2+}, \mathrm{Cu}^{2+}, \mathrm{Cr}^{3+} / \mathrm{Cr}^{6+}, \mathrm{Cd}^{2+}, \mathrm{Ca}^{2+}, \mathrm{Ba}^{2+}, \mathrm{Co}^{2+}, \mathrm{Mg}^{2+}, \mathrm{Ag}^{+}, \mathrm{Fe}^{3+}, \mathrm{Zn}^{2+}, \mathrm{Al}^{3+}$ and for different anions such as $\mathrm{NO}_{2}^{-}, \mathrm{F}^{-}, \mathrm{CN}^{-}, \mathrm{PFAS}, \mathrm{OCl}^{-}, \mathrm{I}^{-}, \mathrm{SO}_{3}{ }^{2-}, \mathrm{S}^{2-}$ or $\mathrm{SO}_{4}{ }^{2-}$ 
Table 3. Summary of colorimetric Au/Ag NPs system for ion sensing.

\begin{tabular}{|c|c|c|c|c|c|}
\hline Ion & Receptor molecules & Sensitivity & Interferences & $\begin{array}{c}\text { Type of } \\
\text { colorimetric } \\
\text { detection }\end{array}$ & Reference \\
\hline \multirow[b]{3}{*}{$\mathrm{K}^{+}$} & Crown ether & $\begin{array}{c}\text { LOD: } 7.6 \mu \mathrm{M} \text {, } \\
\text { linear range: } 7.6 \\
\mu \mathrm{M}-0.14 \mathrm{mM}\end{array}$ & $\begin{array}{c}\mathrm{Li}^{+}, \mathrm{Na}^{+}, \mathrm{Cs}^{+} \\
\mathrm{Mg}^{2+}, \mathrm{Ca}^{2+} \\
\mathrm{NH}_{4}^{+}\end{array}$ & $\begin{array}{l}\text { Aggregation- } \\
\text { based }\end{array}$ & $(188)$ \\
\hline & Aptamer & $\begin{array}{l}\text { LOD of } 71.6 \mathrm{pM} \text {, } \\
\text { linear range: } \\
60-120 \mathrm{nM}\end{array}$ & $\begin{array}{c}\mathrm{Li}^{+}, \mathrm{Na}^{+}, \mathrm{Mg}^{2+} \\
\mathrm{Ca}^{2+}, \mathrm{Fe}^{3+}, \mathrm{Cu}^{+} \\
\mathrm{Zn}^{2+}\end{array}$ & $\begin{array}{l}\text { Aggregation- } \\
\text { based }\end{array}$ & (195) \\
\hline & Crown ether & $\begin{array}{l}\text { LOD of } 5.24 \\
\mu \mathrm{M} \text {, linear } \\
\text { range: } 0-200 \\
\mu \mathrm{M}\end{array}$ & $\begin{array}{c}\mathrm{Li}^{+}, \mathrm{Na}^{+}, \mathrm{Mg}^{2+} \\
\mathrm{Ca}^{2+}, \mathrm{Ba}^{2+} \\
\mathrm{Mn}^{2+}, \mathrm{Fe}^{3+} \\
\mathrm{Co}^{2+}, \mathrm{Ni}^{2+}, \mathrm{Cu}^{2+} \\
\mathrm{Zn}^{2+}, \mathrm{Al}^{3+}, \mathrm{Pb}^{2+} \\
\mathrm{NH}_{4}{ }^{+}, \mathrm{PO}_{4}^{3-} \\
\mathrm{SO}_{4}{ }^{2-}, \mathrm{CO}_{3}^{2-}\end{array}$ & $\begin{array}{l}\text { Aggregation- } \\
\text { based }\end{array}$ & $(196)$ \\
\hline
\end{tabular}


Table 3. Summary of colorimetric Au/Ag NPs system for ion sensing.

\begin{tabular}{|c|c|c|c|c|c|}
\hline \multirow{3}{*}{$\begin{array}{c}\mathrm{As}^{3+} / \mathrm{AsO}_{3}^{3-} \\
{ }^{3-} \mathrm{AsO}_{4}^{3-}\end{array}$} & $\begin{array}{c}\text { Glutathione(GSH), DTT, and } \\
\text { cysteine (Cys) }\end{array}$ & $\begin{array}{c}\text { LOD: } 3 \text { ppt, } \\
\text { linear range: } 0 \\
\text { ppt to } 450 \mathrm{ppt}\end{array}$ & $\begin{array}{c}\mathrm{Fe}^{2+}, \mathrm{Cu}^{2+} \\
\mathrm{Zn}^{2+}, \mathrm{Hg}^{2+}, \mathrm{Pb}^{2+}\end{array}$ & $\begin{array}{l}\text { Aggregation- } \\
\text { based }\end{array}$ & $(189)$ \\
\hline & Aptamer and a cationic polymer & LOD: 5.3 ppb & $\begin{array}{c}\mathrm{Mg}^{2+}, \mathrm{Ca}^{2+} \\
\mathrm{Mn}^{2+}, \mathrm{Fe}^{2+} \\
\mathrm{Fe}^{3+}, \mathrm{Ni}^{2+} \\
\mathrm{Cu}^{2+}, \mathrm{Ag}^{+}, \mathrm{Zn}^{2+} \\
\mathrm{Cd}^{2+}, \mathrm{Hg}^{2+} \\
\mathrm{Pb}^{2+}, \mathrm{As}^{5+}\end{array}$ & $\begin{array}{l}\text { Aggregation- } \\
\text { based }\end{array}$ & $(197)$ \\
\hline & $\begin{array}{l}\text { Tetradecyl (trihexyl) phosphonium } \\
\text { chloride ionic liquid }\end{array}$ & LOD: $7.5 \mu \mathrm{g} \mathrm{L}^{-1}$ & $\begin{array}{c}\mathrm{Na}^{+}, \mathrm{K}^{+}, \mathrm{Mg}^{2+} \\
\mathrm{Ca}^{2+}, \mathrm{Cr}^{3+} \\
\mathrm{Mn}^{2+}, \mathrm{Fe}^{3+}, \mathrm{Ni}^{2+}, \\
\mathrm{Zn}^{2+}, \mathrm{Cd}^{2+}, \\
\mathrm{Hg}^{2+}, \mathrm{Al}^{3+}, \mathrm{Pb}^{2+}, \\
\mathrm{SO}_{4}{ }^{2-}, \mathrm{CO}_{3}{ }^{2-} \\
\mathrm{PO}_{4}{ }^{3-}, \mathrm{NO}_{2-} \\
\mathrm{SiO}_{3}{ }^{2}\end{array}$ & $\begin{array}{l}\text { Aggregation- } \\
\text { based }\end{array}$ & $(198)$ \\
\hline
\end{tabular}


Table 3. Summary of colorimetric Au/Ag NPs system for ion sensing.

Lauryl sulphate (LS)

\section{Citrate}

\section{GSH, DTT and Asparagine (Asn)}

$$
\begin{array}{ccc} 
& \mathrm{Na}^{+}, \mathrm{K}^{+}, \mathrm{Mg}^{2+}, & \\
\text { LOD: } 2 \mu \mathrm{gL}^{-1}, & \mathrm{Ca}^{2+}, \mathrm{Ba}^{2+}, \mathrm{Cr}^{3+}, & \\
\text { linear range: } 5- & \mathrm{Fe}^{3+}, \mathrm{Co}^{2+}, \mathrm{Ni}^{2+}, & \text { Aggregation- } \\
500 \mu \mathrm{g} \mathrm{L}^{-1} & \mathrm{Cu}^{2+}, \mathrm{Zn}^{2+}, & \text { based } \\
& \mathrm{Cd}^{2+}, \mathrm{Hg}^{2+}, \mathrm{Al}^{3+}, & \\
\mathrm{Pb}^{2+} &
\end{array}
$$

$$
\begin{aligned}
& \mathrm{Na}^{+}, \mathrm{K}^{+}, \mathrm{Mg}^{2+}, \\
& \mathrm{Ca}^{2+}, \mathrm{Cr}^{3+}, \\
& \mathrm{Mn}^{2+}, \mathrm{Fe}^{2+}, \quad \text { Aggregation- } \\
& \mathrm{Fe}^{3+}, \mathrm{Ni}^{2+}, \mathrm{Cu}^{2+}, \quad \text { based } \\
& \mathrm{Zn}^{2+}, \mathrm{Cd}^{2+}, \\
& \mathrm{Hg}^{2+}, \mathrm{Pb}^{2+}
\end{aligned}
$$

linear range: $4-$

$100 \mathrm{ppb}$

$$
\mathrm{Na}^{+}, \mathrm{K}^{+}, \mathrm{Mg}^{2+} \text {, }
$$

LOD: $0.36 \mathrm{ppb}$,

$\mathrm{Ca}^{2+}, \mathrm{Ba}^{2+}, \mathrm{Cr}^{3+}$

$$
\begin{aligned}
& \text { linear range: } \\
& 0.4-20 \mathrm{ppb}
\end{aligned}
$$$$
\mathrm{Fe}^{2+}, \mathrm{Fe}^{3+}, \mathrm{Ni}^{2+} \text {, Aggregation- }
$$$$
\mathrm{Cu}^{2+}, \mathrm{Zn}^{2+}, \quad \text { based }
$$ 
Table 3. Summary of colorimetric Au/Ag NPs system for ion sensing.

\begin{tabular}{|c|c|c|c|c|c|}
\hline & $\begin{array}{c}\text { Poly(ethylene glycol) methyl } \\
\text { etherthiol (mPEG-SH) and meso- } \\
\text { 2,3-dimercaptosuccinic acid } \\
\text { (DMSA) }\end{array}$ & $\begin{array}{c}\text { LOD: } \sim 1.0 \mathrm{ppb} \text {, } \\
\text { linear range: } \\
\text { 0.001-10 ppm }\end{array}$ & $\begin{array}{c}\mathrm{Na}^{+}, \mathrm{K}^{+}, \mathrm{Ca}^{2+}, \\
\mathrm{Cr}^{3+}, \mathrm{Fe}^{3+}, \mathrm{Cu}^{2+}, \\
\mathrm{Cd}^{2+}, \mathrm{Hg}^{2+}, \mathrm{Pb}^{2+}\end{array}$ & $\begin{array}{l}\text { Aggregation- } \\
\text { based }\end{array}$ & $(202)$ \\
\hline & $\begin{array}{c}\text { Mercapto-4-methyl-5-thiazoleacetic } \\
\text { acid and europium }\end{array}$ & $\begin{array}{l}\text { LOD: } \leq 10.0 \\
\text { ppb, linear } \\
\text { range: } 0.001-10 \\
\text { ppm }\end{array}$ & $\begin{array}{l}\mathrm{Na}^{+}, \mathrm{K}^{+}, \mathrm{Mg}^{2+} \\
\mathrm{Ca}^{2+}, \mathrm{Cr}^{3+}, \mathrm{Fe}^{3+} \\
\mathrm{Cu}^{2+}, \mathrm{Cd}^{2+} \\
\mathrm{Hg}^{2+}, \mathrm{Pb}^{2+}, \mathrm{F}^{-}\end{array}$ & $\begin{array}{l}\text { Aggregation- } \\
\text { based }\end{array}$ & $(203)$ \\
\hline \multirow{3}{*}{$\mathrm{Hg}^{2+}$} & DDTC & $\begin{array}{l}\text { LOD: } 10 \mathrm{nM} \text {, } \\
\text { linear range: } \\
0.01 \text { to } 1.5 \mu \mathrm{M}\end{array}$ & $\begin{array}{c}\mathrm{Mg}^{2+}, \mathrm{Ba}^{2+}, \\
\mathrm{Mn}^{2+}, \mathrm{Co}^{2+}, \mathrm{Ag}^{+}, \\
\mathrm{Zn}^{2+}, \mathrm{Cd}^{2+}, \mathrm{Pb}^{2+}\end{array}$ & $\begin{array}{l}\text { Aggregation- } \\
\text { based }\end{array}$ & $(191)$ \\
\hline & Cys & $\begin{array}{l}\text { LOD: } 2.6 \mathrm{nM} \text {, } \\
\text { linear range: } \\
0.001-1 \mu \mathrm{M}\end{array}$ & $\begin{array}{c}\mathrm{Ca}^{2+}, \mathrm{Mn}^{2+} \\
\mathrm{Fe}^{3+}, \mathrm{Co}^{2+}, \mathrm{Ni}^{2+} \\
\mathrm{Cu}^{2+}, \mathrm{Zn}^{2+} \\
\mathrm{Cd}^{2+}, \mathrm{Al}^{3+}, \mathrm{Pb}^{2+}\end{array}$ & $\begin{array}{l}\text { Aggregation- } \\
\text { based }\end{array}$ & (204) \\
\hline & 8-hydroxyquinolines and oxalates & $\begin{array}{l}\text { LOD: } 10 \mathrm{nM} \text {, } \\
\text { linear range: } 10 \\
\mathrm{nM} \text { to } 100 \mathrm{mM}\end{array}$ & $\begin{array}{l}\mathrm{Na}^{+}, \mathrm{K}^{+}, \mathrm{Mg}^{2+} \\
\mathrm{Ca}^{2+}, \mathrm{Ba}^{2+}, \mathrm{Cr}^{3+} \\
\mathrm{Cr}^{6+}, \mathrm{Fe}^{3+}, \mathrm{Co}^{2+} \\
\mathrm{Ni}^{2+}, \mathrm{Cu}^{2+}, \mathrm{Zn}^{2+}\end{array}$ & $\begin{array}{l}\text { Aggregation- } \\
\text { based }\end{array}$ & (205) \\
\hline
\end{tabular}


Table 3. Summary of colorimetric Au/Ag NPs system for ion sensing.

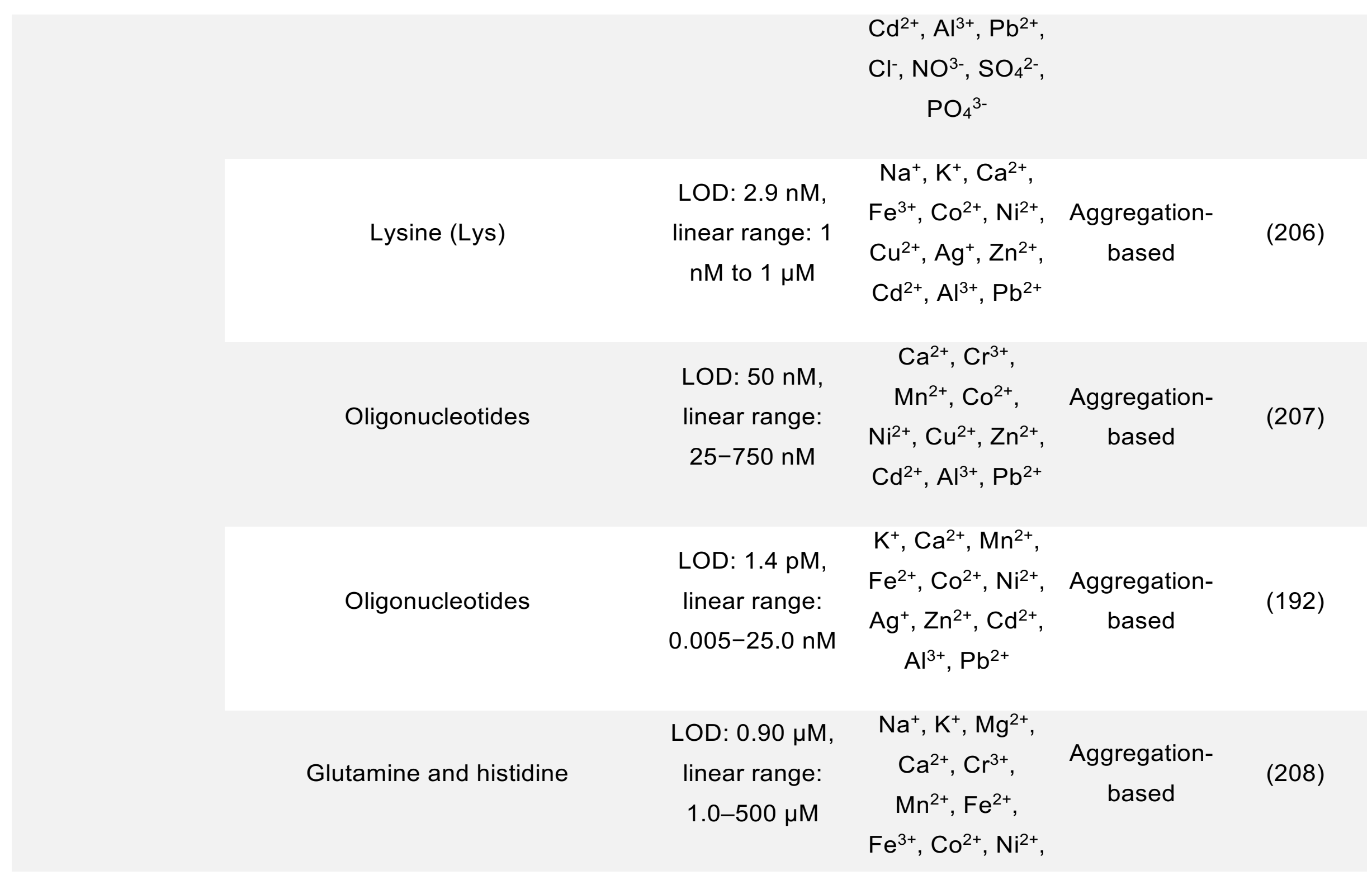


Table 3. Summary of colorimetric Au/Ag NPs system for ion sensing.

\begin{tabular}{|c|c|c|c|c|}
\hline & & $\begin{array}{c}\mathrm{Cu}^{2+}, \mathrm{Zn}^{2+} \\
\mathrm{Cd}^{2+}, \mathrm{Al}^{3+}, \mathrm{Pb}^{2+}\end{array}$ & & \\
\hline $\begin{array}{l}\text { Catalytic reaction of } 3,3^{\prime}, 5,5^{\prime}- \\
\text { tetramethylbenzidine (TMB) and } \\
\qquad \mathrm{H}_{2} \mathrm{O}_{2}\end{array}$ & $\begin{array}{l}\text { LOD: } 30 \mu \mathrm{g} \mathrm{L}^{-1} \\
\text { linear range: } 0.1 \\
\text { and } 200 \mathrm{ng}\end{array}$ & $\begin{array}{c}\mathrm{Na}^{+}, \mathrm{Ca}^{2+}, \mathrm{Mn}^{2+} \\
\mathrm{Fe}^{2+}, \mathrm{Fe}^{3+} \\
\mathrm{Co}^{2+}, \mathrm{Ni}^{2+}, \mathrm{Cu}^{2+} \\
\mathrm{Ag}^{+}, \mathrm{Zn}^{2+}, \mathrm{Cd}^{2+} \\
\mathrm{Pb}^{2+}, \mathrm{As}^{3+} \\
\mathrm{Sb}^{3+}, \mathrm{Bi}^{3+}\end{array}$ & $\begin{array}{l}\text { Enzyme- } \\
\text { mimetic- } \\
\text { based }\end{array}$ & (209) \\
\hline $\begin{array}{l}\text { Catalytic reaction of } 3,3^{\prime}, 5,5^{\prime}- \\
\text { tetramethylbenzidine (TMB) and } \\
\qquad \mathrm{H}_{2} \mathrm{O}_{2}\end{array}$ & $\begin{array}{l}\text { LOD: } 0.07 \mathrm{nM} \text {, } \\
\text { linear range: } \\
\text { 0.1-5 nM }\end{array}$ & $\begin{array}{c}\mathrm{Zr}^{4+}, \mathrm{Cr}^{3+}, \mathrm{Cr}^{6+} \\
\mathrm{Fe}^{2+}, \mathrm{Co}^{2+} \\
\mathrm{Cd}^{2+}, \mathrm{Sn}^{4+} \\
\mathrm{Pb}^{2+}, \mathrm{La}^{3+}, \mathrm{Ce}^{3+}\end{array}$ & $\begin{array}{l}\text { Enzyme- } \\
\text { mimetic- } \\
\text { based }\end{array}$ & (184) \\
\hline $\begin{array}{l}\text { Chitosan and 2,6- } \\
\text { pyridinedicarboxylic acid (PDA) }\end{array}$ & $\begin{array}{l}\text { Linear range: } \\
300 \mathrm{nM} \text { to } 5 \mu \mathrm{M}\end{array}$ & $\begin{array}{c}\mathrm{Li}^{+}, \mathrm{Na}^{+}, \mathrm{K}^{+} \\
\mathrm{Mg}^{2+}, \mathrm{Ca}^{2+} \\
\mathrm{Sr}^{2+}, \mathrm{Fe}^{2+}, \mathrm{Fe}^{3+} \\
\mathrm{Co}^{2+}, \mathrm{Ni}^{2+}, \mathrm{Cu}^{2+} \\
\mathrm{Ag}^{+}, \mathrm{Zn}^{2+}, \mathrm{Cd}^{2+} \\
\mathrm{Al}^{3+}, \mathrm{Pb}^{2+}\end{array}$ & $\begin{array}{l}\text { Aggregation- } \\
\text { based }\end{array}$ & (210) \\
\hline
\end{tabular}


Table 3. Summary of colorimetric Au/Ag NPs system for ion sensing.

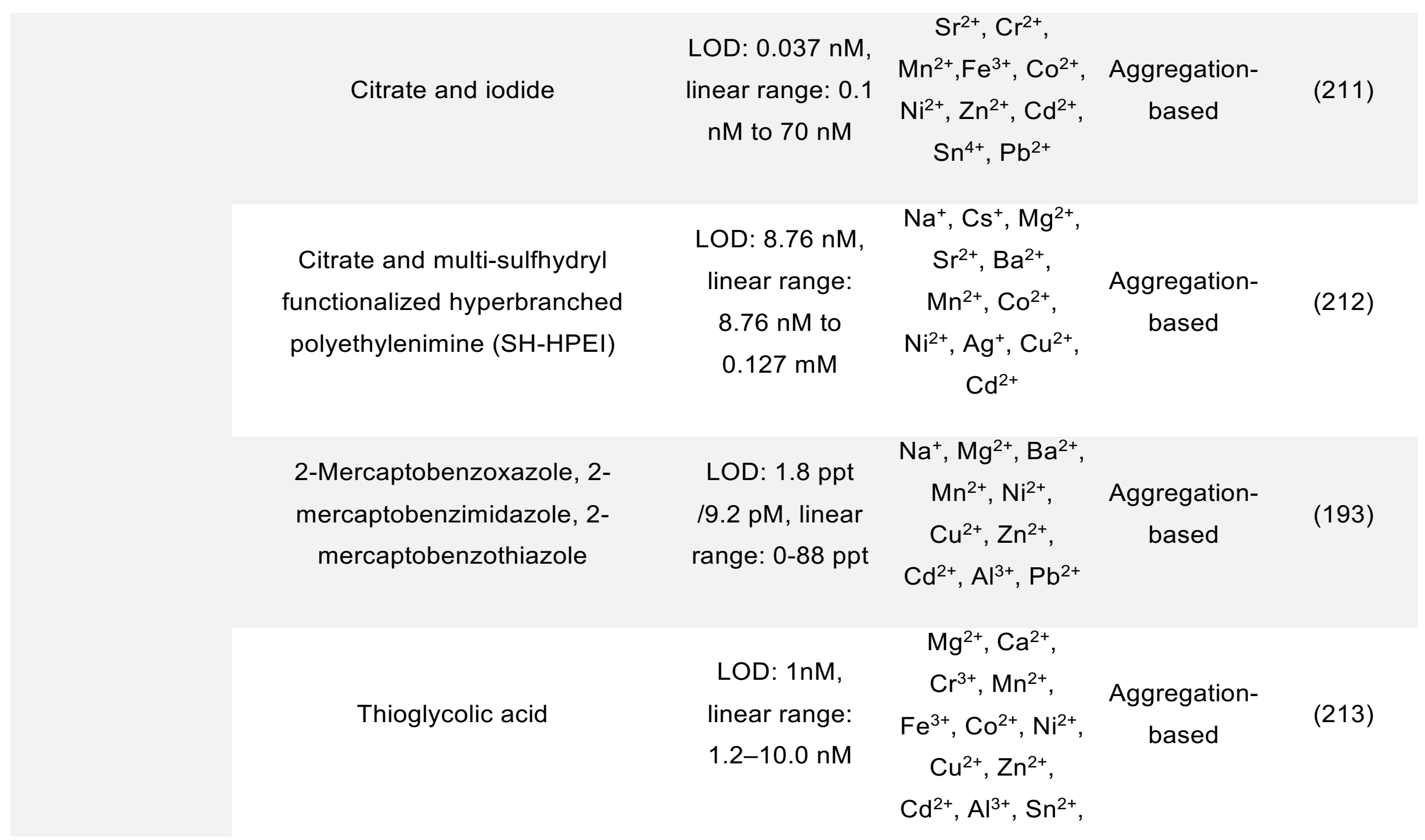


Table 3. Summary of colorimetric Au/Ag NPs system for ion sensing.

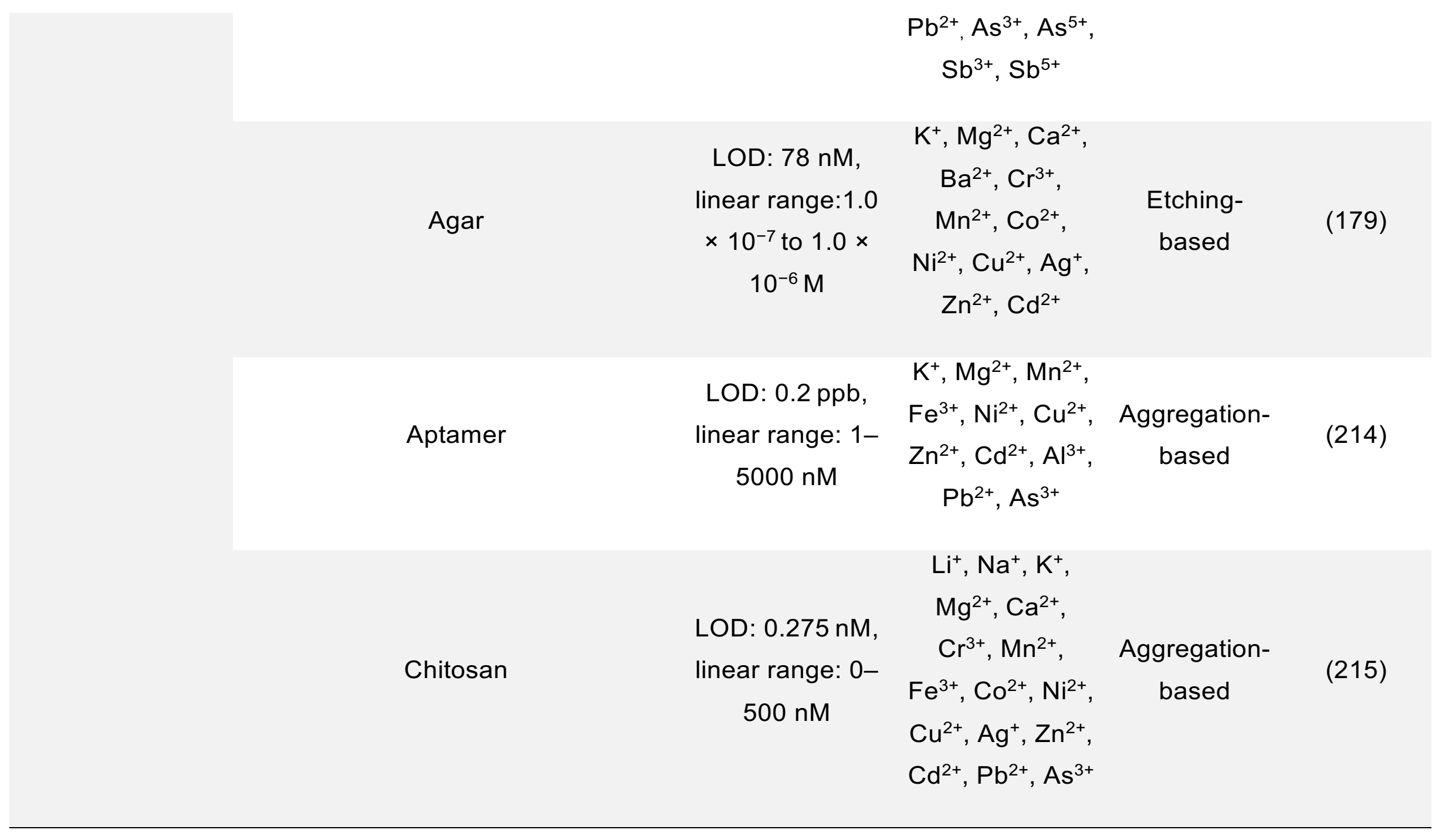




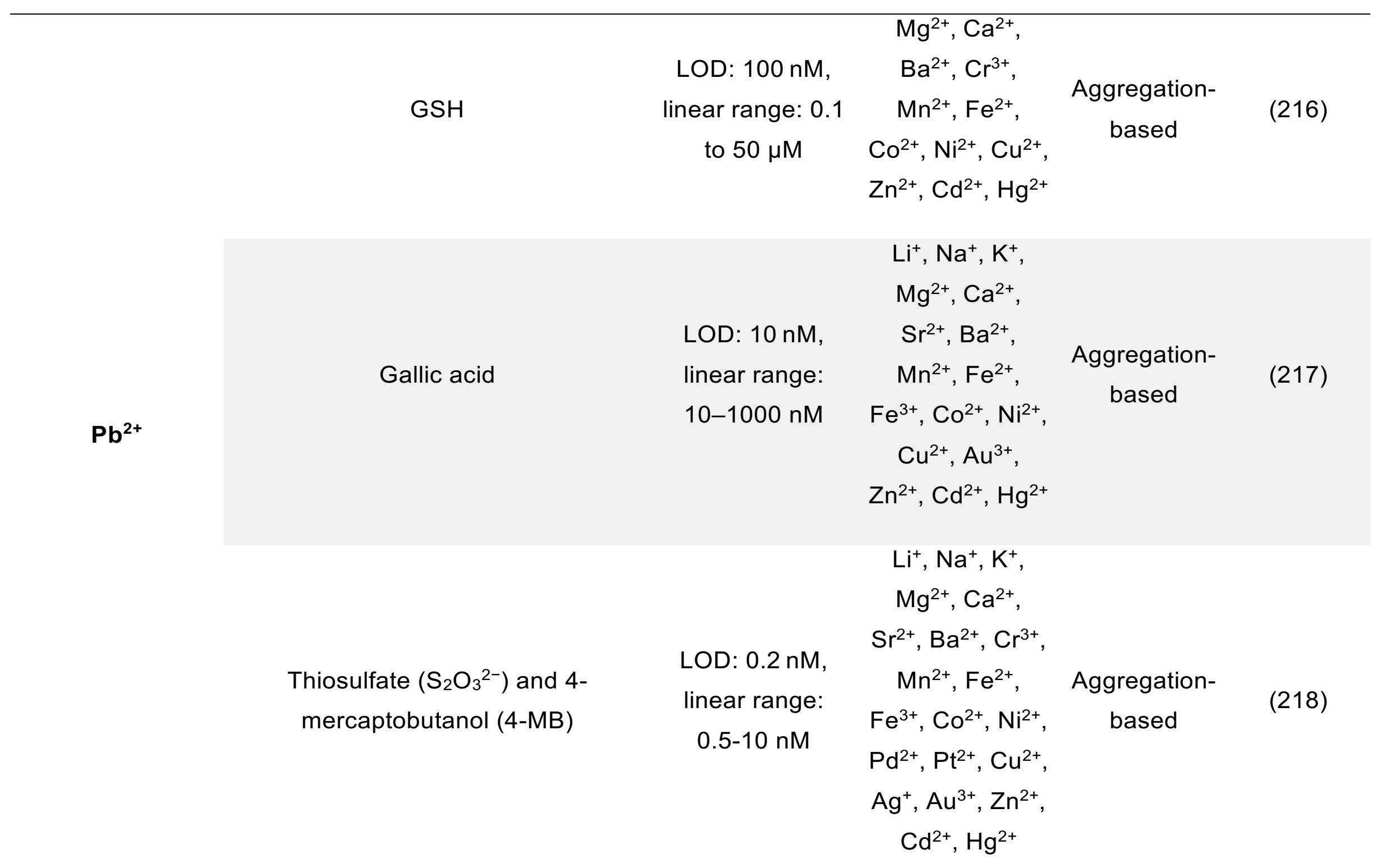


Table 3. Summary of colorimetric Au/Ag NPs system for ion sensing.

\begin{tabular}{|c|c|c|c|c|}
\hline GSH and pentapeptide (CALNN) & $\begin{array}{l}\text { LOD: } 2.9 \text { fmol } \\
\text { per cell, linear } \\
\text { range: } 2.9 \text { to } \\
37.7 \text { fmol per } \\
\text { cell }\end{array}$ & $\begin{array}{c}\mathrm{Na}^{+}, \mathrm{K}^{+}, \mathrm{Mg}^{2+}, \\
\mathrm{Ca}^{2+}, \mathrm{Ba}^{2+} \\
\mathrm{Mn}^{2+}, \mathrm{Fe}^{2+} \\
\mathrm{Fe}^{3+}, \mathrm{Co}^{2+}, \mathrm{Ni}^{2+}, \\
\mathrm{Cu}^{2+}, \mathrm{Zn}^{2+} \\
\mathrm{Cd}^{2+}, \mathrm{Hg}^{2+}, \mathrm{Al}^{3+}\end{array}$ & $\begin{array}{c}\text { Aggregation- } \\
\text { based }\end{array}$ & $(219)$ \\
\hline $\begin{array}{l}\text { Dithiocarbamate derivative of 4'- } \\
\text { aminobenzo-18-crown-6 }\end{array}$ & $\begin{array}{l}\text { LOD: } 50 \mathrm{nM} \text {, } \\
\text { linear range: } \\
0.1 \text { to } 75 \mu \mathrm{M}\end{array}$ & $\begin{array}{c}\mathrm{Na}^{+}, \mathrm{K}^{+}, \mathrm{Mg}^{2+}, \\
\mathrm{Ca}^{2+}, \mathrm{Ba}^{2+}, \mathrm{Cr}^{3+}, \\
\mathrm{Mn}^{2+}, \mathrm{Fe}^{2+} \\
\mathrm{Fe}^{3+}, \mathrm{Co}^{2+}, \mathrm{Ni}^{2+}, \\
\mathrm{Cu}^{2+}, \mathrm{Zn}^{2+} \\
\mathrm{Cd}^{2+}, \mathrm{Hg}^{2+}, \mathrm{Al}^{3+}\end{array}$ & $\begin{array}{c}\text { Aggregation- } \\
\text { based }\end{array}$ & $(220)$ \\
\hline GSH & $\begin{array}{l}\text { LOD: } 0.05 \mathrm{nM} \text {, } \\
\text { linear range: } \\
\text { 2.40-48.26 nM }\end{array}$ & $\begin{array}{c}\mathrm{Mg}^{2+}, \mathrm{Ca}^{2+}, \\
\mathrm{Cr}^{2+}, \mathrm{Mn}^{2+} \\
\mathrm{Fe}^{2+}, \mathrm{Ni}^{2+}, \mathrm{Cd}^{2+} \\
\mathrm{Hg}^{2+}\end{array}$ & $\begin{array}{l}\text { Aggregation- } \\
\text { based }\end{array}$ & (221) \\
\hline DNA strands & $\begin{array}{l}\text { LOD: } 3.4 \mathrm{nM} \text {, } \\
\text { linear range: 0- } \\
100 \mathrm{nM}\end{array}$ & $\begin{array}{l}\mathrm{Mg}^{2+}, \mathrm{Ca}^{2+} \\
\mathrm{Mn}^{2+}, \mathrm{Fe}^{3+}\end{array}$ & $\begin{array}{c}\text { Aggregation- } \\
\text { based }\end{array}$ & $(222)$ \\
\hline
\end{tabular}


Table 3. Summary of colorimetric Au/Ag NPs system for ion sensing.

$$
\begin{gathered}
\mathrm{Co}^{2+}, \mathrm{Ni}^{2+}, \mathrm{Cu}^{2+} \\
\mathrm{Zn}^{2+}, \mathrm{Cd}^{2+}
\end{gathered}
$$

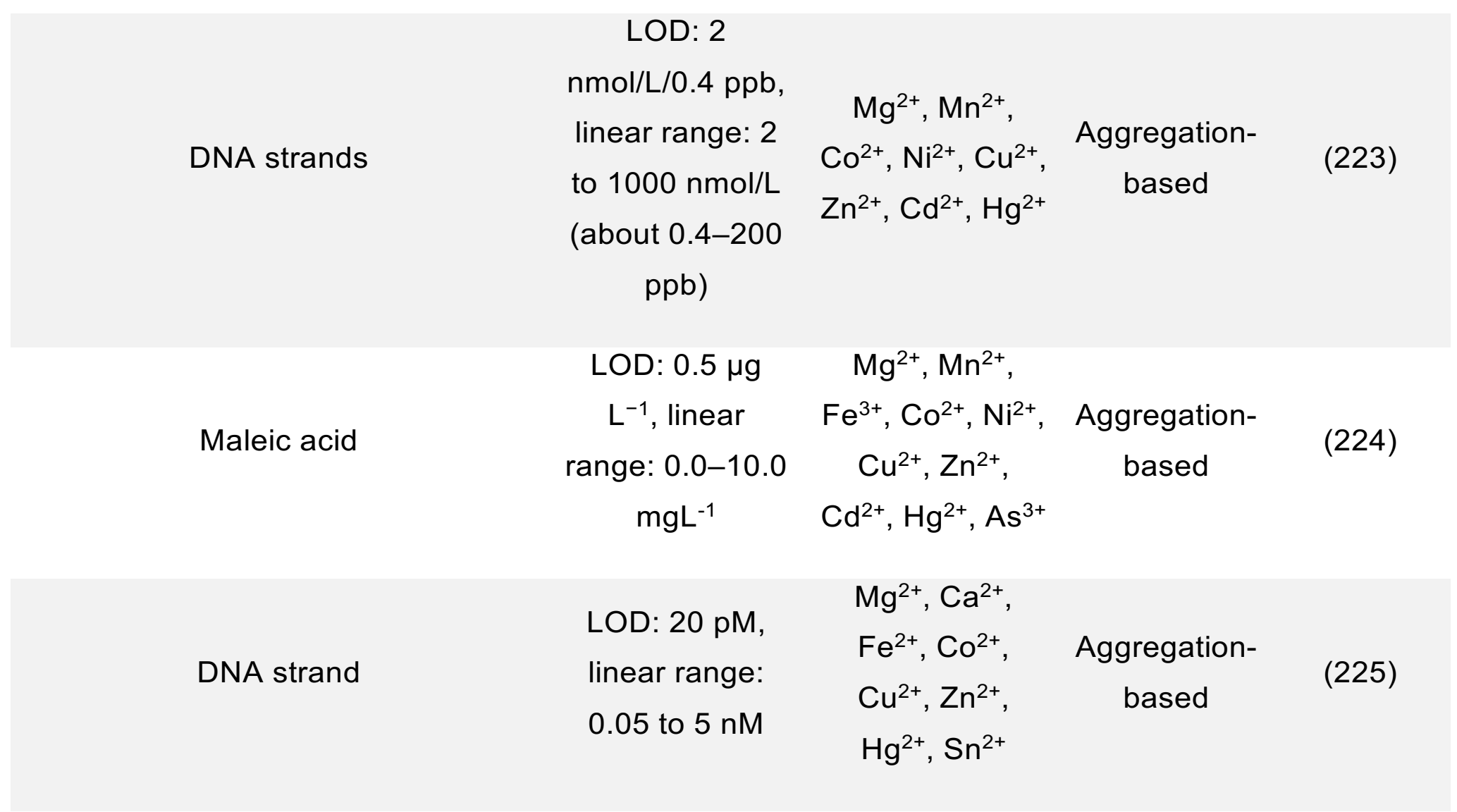


Table 3. Summary of colorimetric Au/Ag NPs system for ion sensing.

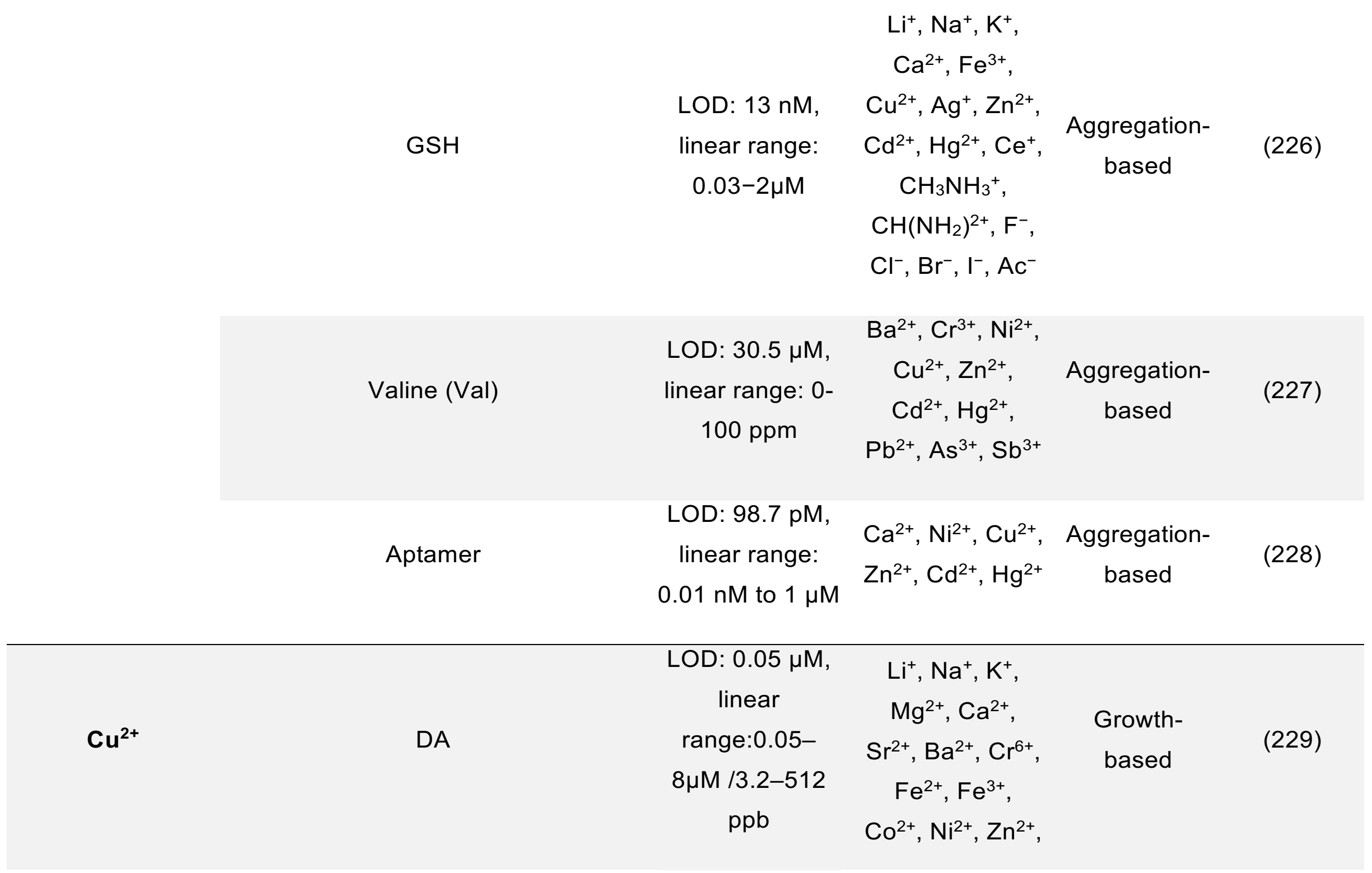




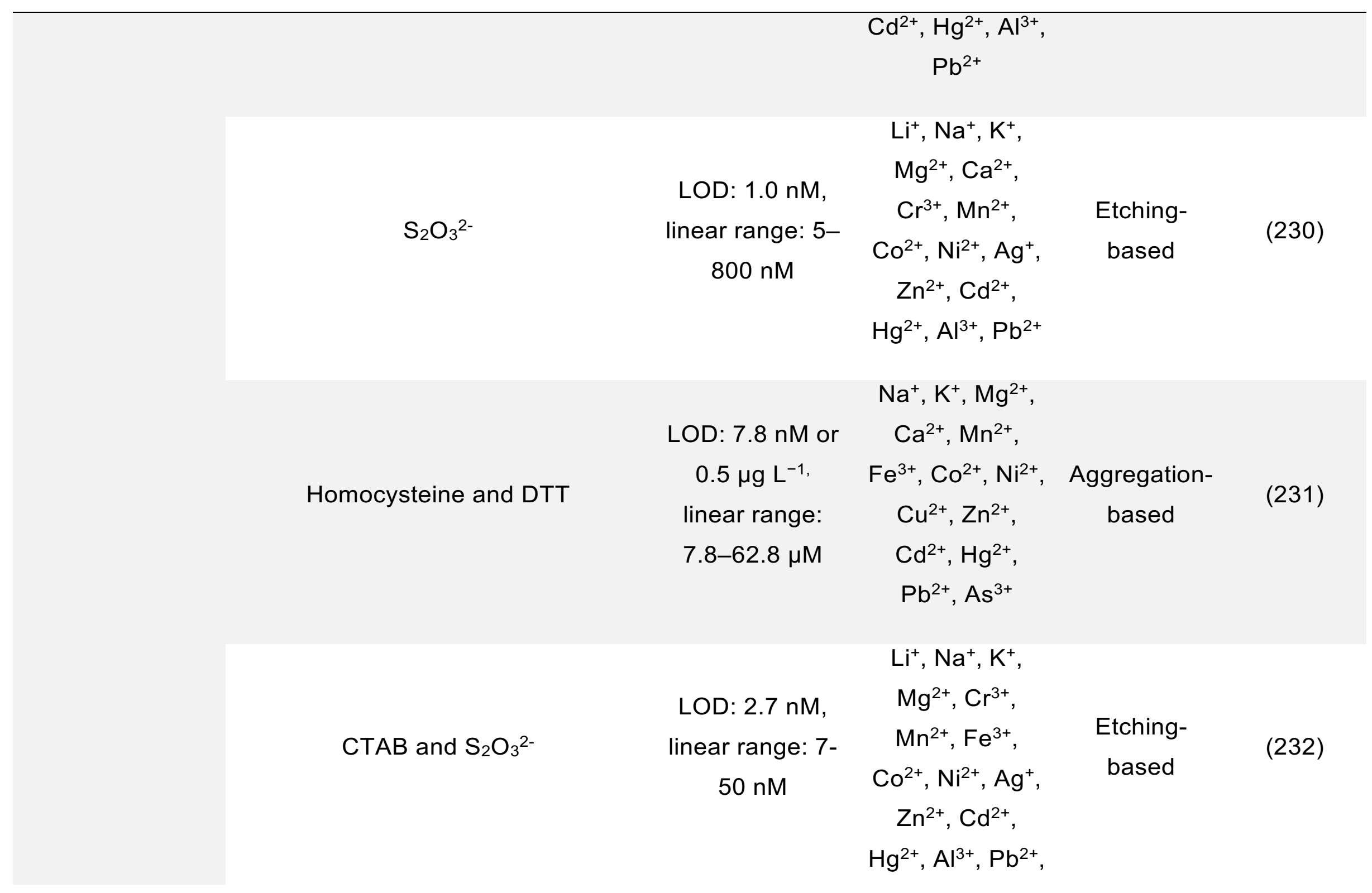


Table 3. Summary of colorimetric Au/Ag NPs system for ion sensing.

\begin{tabular}{|c|c|c|c|c|c|}
\hline & & & $\begin{array}{c}\mathrm{As}^{5+} \\
\mathrm{NO}_{3}^{-}, \mathrm{SO}_{4}^{2-} \\
\mathrm{ClO}_{4}^{-}, \mathrm{NO}_{2}^{-}\end{array}$ & & \\
\hline & L-cys & $\begin{array}{l}\text { LOD: } 2.23 \mu \mathrm{M} \text {, } \\
\text { linear range: } \\
\text { 30-90 } \mu \mathrm{M}\end{array}$ & $\begin{array}{c}\mathrm{Mg}^{2+}, \mathrm{Ca}^{2+} \\
\mathrm{Mn}^{2+}, \mathrm{Zn}^{2+}\end{array}$ & $\begin{array}{l}\text { Aggregation- } \\
\text { based }\end{array}$ & (233) \\
\hline & DA & $\begin{array}{l}\text { LOD: } 9.8 \mathrm{nM} \text {, } \\
\text { linear range: } \\
0.02-1.5 \mu \mathrm{M}\end{array}$ & $\begin{array}{l}\mathrm{Na}^{+}, \mathrm{Mg}^{2+}, \mathrm{Ca}^{2+} \\
\mathrm{Cr}^{3+}, \mathrm{Cr}^{6+}, \mathrm{Fe}^{3+} \\
\mathrm{Co}^{2+}, \mathrm{Ni}^{2+}, \mathrm{Zn}^{2+} \\
\mathrm{Cd}^{2+}, \mathrm{Hg}^{2+}, \mathrm{Pb}^{2+}\end{array}$ & $\begin{array}{l}\text { Aggregation- } \\
\text { based }\end{array}$ & $(234)$ \\
\hline $\mathrm{Cr}^{3+} / \mathrm{Cr}^{6+}$ & $\begin{array}{l}\text { Dithiocarbamate-modified N-benzyl- } \\
\text { 4-(pyridin-4-ylmethyl)aniline ligand } \\
\text { (BP-DTC) }\end{array}$ & $\begin{array}{l}\text { LOD: } 31 \mathrm{ppb} \text {, } \\
\text { linear ranges: } \\
\text { 0-4× } 10^{-1} \mathrm{M} \\
\text { and 4-8 } 80^{-1} \\
\mathrm{M}\end{array}$ & $\begin{array}{c}\mathrm{Mo}^{5+}, \mathrm{W}^{6+} \\
\mathrm{Mn}^{2+}, \mathrm{Fe}^{3+} \\
\mathrm{Co}^{2+}, \mathrm{Ni}^{2+}, \mathrm{Pt}^{4+} \\
\mathrm{Cu}^{2+}, \mathrm{Zn}^{2+} \\
\mathrm{Hg}^{2+}, \mathrm{Pb}^{2+} \\
\mathrm{Cr}_{2} \mathrm{O}_{7}^{2-}\end{array}$ & $\begin{array}{l}\text { Aggregation- } \\
\text { based }\end{array}$ & (235) \\
\hline
\end{tabular}


Table 3. Summary of colorimetric Au/Ag NPs system for ion sensing.

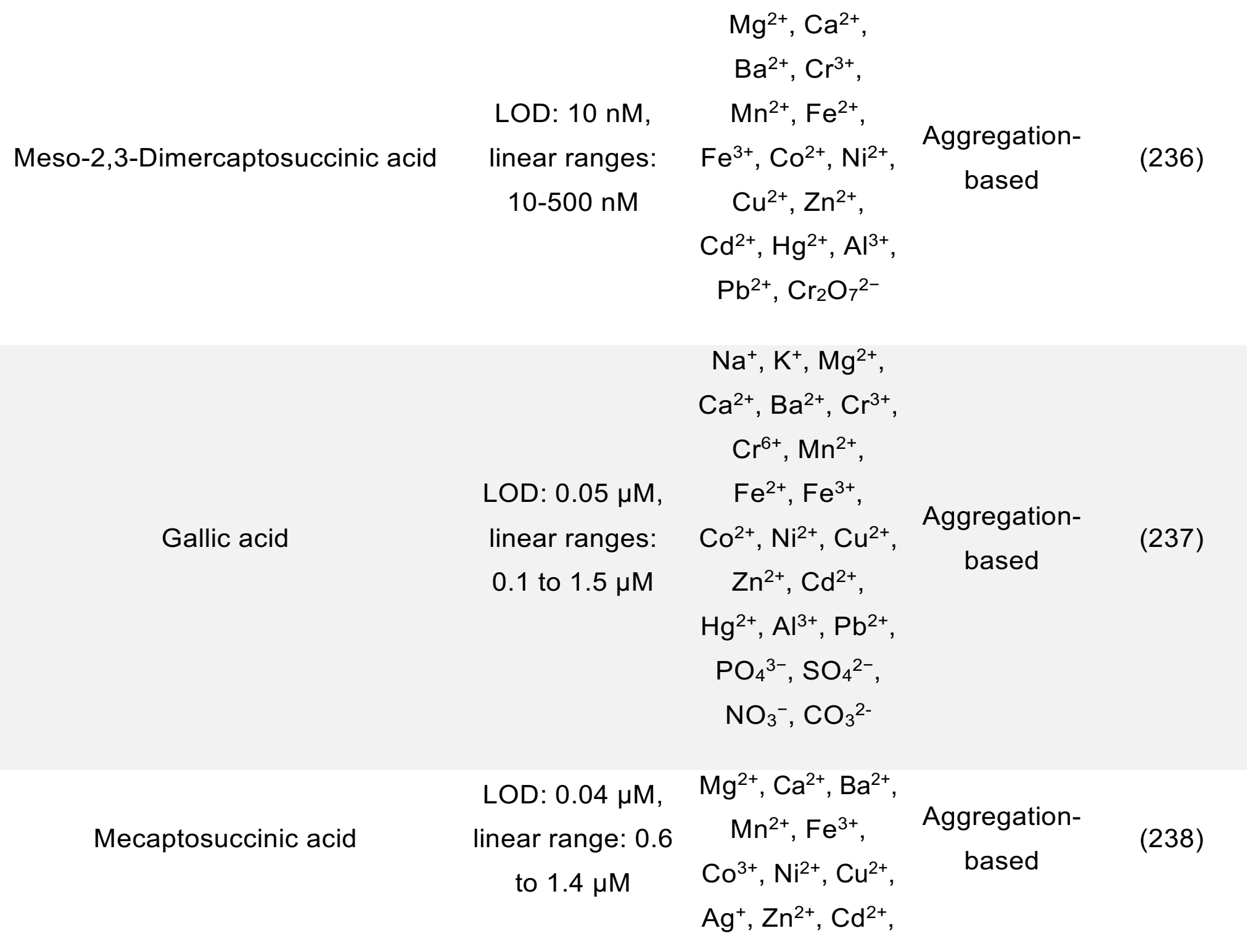


Table 3. Summary of colorimetric Au/Ag NPs system for ion sensing.

\begin{tabular}{|c|c|c|c|c|c|}
\hline & Citrate & $\begin{array}{c}\text { LOD: } 0.4 \mathrm{nM} \text {, } \\
\text { linear range: } \\
\text { 0.001-0.009 } \mathrm{MM}\end{array}$ & $\begin{array}{c}\mathrm{Hg}^{2+}, \mathrm{Al}^{3+}, \mathrm{Pb}^{2+}, \\
\mathrm{Cr}_{2} \mathrm{O}_{7}^{2-} \\
\mathrm{Li}^{+}, \mathrm{Na}^{+}, \mathrm{Mg}^{2+}, \\
\mathrm{Ca}^{2+}, \mathrm{Ba}^{2+}, \mathrm{Cr}^{3+}, \\
\mathrm{Mn}^{2+}, \mathrm{Fe}^{3+} \\
\mathrm{Co}^{3+}, \mathrm{Ni}^{2+}, \mathrm{Cu}^{2+} \\
\mathrm{Cd}^{2+}, \mathrm{Al}^{3+}, \mathrm{Ga}^{3+} \\
\mathrm{Ge}^{4+}, \mathrm{Sn}^{2+}, \mathrm{As}^{3+}, \\
\mathrm{F}^{-}, \mathrm{Cl}^{-}, \mathrm{Br}^{-}, \mathrm{I}^{-} \\
\mathrm{NO}_{3}{ }^{-}, \mathrm{NO}_{2}^{-}, \mathrm{SO}_{4}^{2-} \\
, \mathrm{ClO}_{4}, \mathrm{PO}_{4}^{3-} \\
\mathrm{CH}_{3} \mathrm{CO}_{2}^{-} \\
\mathrm{C}_{3} \mathrm{H}_{5} \mathrm{O}_{\left(\mathrm{COO}_{3}{ }^{3-}\right.}, \\
\mathrm{C}_{6} \mathrm{H}_{5}\left(\mathrm{COO}^{-}\right.\end{array}$ & $\begin{array}{l}\text { Aggregation- } \\
\text { based }\end{array}$ & (239) \\
\hline $\mathrm{Cd}^{2+}$ & $\begin{array}{l}\text { 4-amino-3-hydrazino-5-mercapto- } \\
\text { 1,2,4-triazole }\end{array}$ & $\begin{array}{l}\text { LOD: } 30 \mathrm{nM} \text {, } \\
\text { linear range: 60- } \\
480 \mathrm{nM}\end{array}$ & $\begin{array}{c}\mathrm{Na}^{+}, \mathrm{Mg}^{2+}, \mathrm{Ca}^{2+} \\
\mathrm{Mn}^{2+}, \mathrm{Fe}^{2+}, \mathrm{Fe}^{3+} \\
\mathrm{Co}^{2+}, \mathrm{Ni}^{2+}, \mathrm{Cu}^{2+} \\
\mathrm{Ag}^{+}, \mathrm{Zn}^{2+} \\
\mathrm{Cd}^{2+}, \mathrm{Hg}^{2+}, \mathrm{Al}^{3+} \\
\mathrm{Pb}^{2+}\end{array}$ & $\begin{array}{l}\text { Aggregation- } \\
\text { based }\end{array}$ & $(240)$ \\
\hline
\end{tabular}


Table 3. Summary of colorimetric Au/Ag NPs system for ion sensing.

\begin{tabular}{|c|c|c|c|c|}
\hline \multirow[b]{2}{*}{ GSH } & \multicolumn{3}{|c|}{$\mathrm{Mg}^{2+}, \mathrm{Ca}^{2+}, \mathrm{Mn}^{2+}$} & \multirow[b]{2}{*}{$(241)$} \\
\hline & $\begin{array}{l}\text { LOD: } 10 \mu \mathrm{M} \text {, } \\
\text { linear range: 0-50 } \\
\mu \mathrm{M}\end{array}$ & $\begin{array}{c}\mathrm{Fe}^{3+}, \mathrm{Co}^{2+}, \mathrm{Ni}^{2+} \\
\mathrm{Cu}^{2+}, \mathrm{Ag}^{+}, \mathrm{Zn}^{2+} \\
\mathrm{Cd}^{2+}, \mathrm{Hg}^{2+}, \mathrm{Al}^{3+} \\
\mathrm{Pb}^{2+}\end{array}$ & $\begin{array}{l}\text { Aggregation- } \\
\text { based }\end{array}$ & \\
\hline Di-(1H-pyrrol-2-yl)methanethione & $\begin{array}{l}\text { LOD: } 16.6 \mathrm{nM} \text {, } \\
\text { linear range: } 0.5- \\
16 \mu \mathrm{M}\end{array}$ & $\begin{array}{l}\mathrm{Mg}^{2+}, \mathrm{Ca}^{2+}, \mathrm{Cr}^{3+} \\
\mathrm{Mn}^{2+}, \mathrm{Fe}^{2+}, \mathrm{Fe}^{3+} \\
\mathrm{Co}^{2+}, \mathrm{Ni}^{2+}, \mathrm{Cu}^{2+} \\
\mathrm{Ag}^{+}, \mathrm{Zn}^{2+}, \mathrm{Cd}^{2+} \\
\mathrm{Hg}^{2+}, \mathrm{Al}^{3+}, \mathrm{Pb}^{2+}\end{array}$ & $\begin{array}{l}\text { Aggregation- } \\
\text { based }\end{array}$ & $(242)$ \\
\hline Chitosan dithiocarbamate & $\begin{array}{l}\text { LOD: } 63 \mathrm{nM} \text {, } \\
\text { linear range: } 50- \\
500 \mu \mathrm{M}\end{array}$ & $\begin{array}{c}\mathrm{Na}^{+}, \mathrm{K}^{+}, \mathrm{Mg}^{2+} \\
\mathrm{Ca}^{2+}, \mathrm{Cr}^{3+}, \mathrm{Mn}^{2+} \\
\mathrm{Fe}^{2+}, \mathrm{Fe}^{+}, \mathrm{Co}^{3+}, \\
\mathrm{Ni}^{2+}, \mathrm{Cu}^{2+}, \mathrm{Cd}^{2+}, \\
\mathrm{Hg}^{2+}, \mathrm{Al}^{3+}, \mathrm{Pb}^{3+}\end{array}$ & $\begin{array}{l}\text { Aggregation- } \\
\text { based }\end{array}$ & $(243)$ \\
\hline $\begin{array}{c}\text { Ethyl 1-(2-(3',4'-dihydroxyphenyl)-2- } \\
\text { oxoethyl)-1H-1,2,3-triazole-4- } \\
\text { carboxylate (ETC) }\end{array}$ & $\begin{array}{l}\text { LOD: } 3.02 \mu \mathrm{M} \text {, } \\
\text { linear range: 0-80 } \\
\mu \mathrm{M}\end{array}$ & $\begin{array}{l}\mathrm{Na}^{+}, \mathrm{K}^{+}, \mathrm{Mg}^{2+} \\
\mathrm{Ca}^{2+}, \mathrm{Cr}^{3+}, \mathrm{Zn}^{2+} \\
\mathrm{Hg}^{2+}, \mathrm{Al}^{3+}, \mathrm{Pb}^{3+}\end{array}$ & $\begin{array}{l}\text { Aggregation- } \\
\text { based }\end{array}$ & $(244)$ \\
\hline
\end{tabular}


Table 3. Summary of colorimetric Au/Ag NPs system for ion sensing.

\begin{tabular}{|c|c|c|c|c|c|}
\hline $\mathrm{Ca}^{2+}$ & $\begin{array}{l}\text { 1-thiohexyl carboxylic acid and 1- } \\
\text { thiohexyl b-D-lactopyranoside }\end{array}$ & LOD: $1.9 \mu \mathrm{M}$ & $\begin{array}{c}\mathrm{Na}^{+}, \mathrm{K}^{+}, \mathrm{Mg}^{2+} \\
\mathrm{Ca}^{2+}, \mathrm{Fe}^{3+}, \mathrm{Cu}^{2+} \\
\mathrm{Zn}^{2+}\end{array}$ & $\begin{array}{l}\text { Aggregation- } \\
\text { based }\end{array}$ & $(245)$ \\
\hline $\mathrm{Ba}^{2+}$ & $\begin{array}{l}\text { 2-Sulfanylethanesulfonate (MSA) } \\
\text { and 11-mercaptoundecanoic acid } \\
\text { (MUA) }\end{array}$ & $\begin{array}{l}\text { LOD: } 1.25 \mu \mathrm{M} \text {, } \\
\text { linear range: } 2-16 \\
\mu \mathrm{M}\end{array}$ & $\begin{array}{c}\mathrm{K}^{+}, \mathrm{Rb}^{+}, \mathrm{Cs}^{+} \\
\mathrm{Mg}^{2+}, \mathrm{Ca}^{2+}, \mathrm{Ti}^{4+} \\
\mathrm{Zr}^{4+}, \mathrm{Mn}^{2+}, \mathrm{Fe}^{3+} \\
\mathrm{Co}^{2+}, \mathrm{Ni}^{2+}, \mathrm{Cu}^{2+} \\
\mathrm{Ag}^{+}, \mathrm{Zn}^{2+}, \mathrm{Cd}^{2+} \\
\mathrm{Pb}^{2+}, \mathrm{Al}^{3+}, \mathrm{As}^{3+}\end{array}$ & $\begin{array}{l}\text { Aggregation- } \\
\text { based }\end{array}$ & $(246)$ \\
\hline $\mathrm{Co}^{2+}$ & Calix[4]arene & $\begin{array}{l}\text { LOD: } 1.5 \\
\mathrm{nM} / 24 \mathrm{ppb} \text {, } \\
\text { linear range: } \\
0.06-22 \mu \mathrm{M}\end{array}$ & $\begin{array}{c}\mathrm{Li}^{+}, \mathrm{Na}^{+}, \mathrm{K}^{+}, \mathrm{Cs}^{+} \\
\mathrm{Mg}^{2+}, \mathrm{Ca}^{2+}, \mathrm{Sr}^{2+} \\
\mathrm{Ba}^{2+}, \mathrm{Co}^{3+}, \mathrm{Ni}^{2+} \\
\mathrm{Cd}^{2+}, \mathrm{Zn}^{2+}, \mathrm{Hg}^{2+} \\
\mathrm{Pb}^{2+}\end{array}$ & $\begin{array}{l}\text { Aggregation- } \\
\text { based }\end{array}$ & $(247)$ \\
\hline $\mathrm{Mg}^{2+}$ & Tryptophan (Trp) & $\begin{array}{c}\text { LOD: } 0.2 \mu \mathrm{M} \text {, } \\
\text { linear range: } 0.1 \\
\text { to } 0.45 \mu \mathrm{M}\end{array}$ & $\begin{array}{c}\mathrm{Li}^{+}, \mathrm{K}^{+}, \mathrm{Mg}^{2+} \\
\mathrm{Ca}^{2+}, \mathrm{Cr}^{3+}, \mathrm{Mn}^{2+} \\
\mathrm{Co}^{3+}, \mathrm{Cd}^{2+}, \mathrm{Zn}^{3+} \\
\mathrm{Hg}^{3+}, \mathrm{Pb}^{3+}, \mathrm{As}^{3+}\end{array}$ & $\begin{array}{l}\text { Aggregation- } \\
\text { based }\end{array}$ & $(248)$ \\
\hline
\end{tabular}


Table 3. Summary of colorimetric Au/Ag NPs system for ion sensing.

\begin{tabular}{|c|c|c|c|c|c|}
\hline \multirow{4}{*}{$\mathrm{Ag}^{+}$} & & & $\mathrm{K}^{+}, \mathrm{Ca}^{2+}, \mathrm{Mn}^{2+}$ & & \\
\hline & Tris(hydroxymethyl)aminomethane(tris) & $\begin{array}{c}\text { LOD: } 0.41 \mu \mathrm{M} \text {, } \\
\text { linear range: } 1-9 \\
\mu \mathrm{M}\end{array}$ & $\begin{array}{c}\mathrm{Fe}^{2+}, \mathrm{Co}^{2+}, \mathrm{Ni}^{2+} \\
\mathrm{Cu}^{2+}, \mathrm{Ag}^{+}, \mathrm{Zn}^{2+} \\
\mathrm{Cd}^{2+}, \mathrm{Hg}^{2+}, \mathrm{Pb}^{2+} \\
\mathrm{Ce}^{2+}\end{array}$ & $\begin{array}{l}\text { Aggregation- } \\
\text { based }\end{array}$ & $(249)$ \\
\hline & Peptide & $\begin{array}{l}\text { LOD: } 7.4 \mathrm{nM} \text {, } \\
\text { linear range: } \\
\text { 10-1000 nM }\end{array}$ & $\begin{array}{c}\mathrm{Li}^{+}, \mathrm{Na}^{+}, \mathrm{K}^{+} \\
\mathrm{Mg}^{2+}, \mathrm{Ca}^{2+}, \mathrm{Cr}^{3+} \\
\mathrm{Mn}^{2+}, \mathrm{Fe}^{3+}, \mathrm{Co}^{2+} \\
\mathrm{Ni}^{2+}, \mathrm{Cu}^{2+}, \mathrm{Zn}^{2+} \\
\mathrm{Pb}^{2+}, \mathrm{F}^{-}, \mathrm{Cl}^{-} \\
\mathrm{AcO}^{-}, \mathrm{NO}_{2}^{-}, \mathrm{NO}_{3}^{-} \\
\mathrm{CO}_{3}{ }^{2-}, \mathrm{SO}_{4}{ }^{2-}\end{array}$ & $\begin{array}{l}\text { Aggregation- } \\
\text { based }\end{array}$ & $(250)$ \\
\hline & Adenosine and creatinine & $\begin{array}{l}\text { LOD: } 7.3 \mathrm{nM} \text {, } \\
\text { linear range: } \\
0.1-0.9 \mu \mathrm{M}\end{array}$ & $\begin{array}{c}\mathrm{Na}^{+}, \mathrm{K}^{+}, \mathrm{Mg}^{2+}, \\
\mathrm{Ca}^{2+}, \mathrm{Ba}^{2+}, \mathrm{Cr}^{3+}, \\
\mathrm{Mn}^{2+}, \mathrm{Fe}^{3+}, \mathrm{Co}^{2+}, \\
\mathrm{Ni}^{2+}, \mathrm{Cu}^{2+}, \mathrm{Zn}^{2+}, \\
\mathrm{Hg}^{2+}, \mathrm{Pb}^{2+}, \mathrm{F}^{-}, \mathrm{Cl}^{-} \\
, \mathrm{Br}^{-}, \mathrm{NO}_{3}-, \mathrm{HCO}_{3}^{-} \\
, \mathrm{SO}_{4}^{2-}, \\
\mathrm{CH}_{3} \mathrm{COO}^{-}, \mathrm{ClO}_{4}^{-},\end{array}$ & $\begin{array}{l}\text { Aggregation- } \\
\text { based }\end{array}$ & $(251)$ \\
\hline
\end{tabular}


Table 3. Summary of colorimetric Au/Ag NPs system for ion sensing.

\begin{tabular}{|c|c|c|c|c|c|}
\hline & & & $\begin{array}{c}\mathrm{SO}_{3}{ }^{2-}, \mathrm{SCN}^{-} \\
\mathrm{S}_{2} \mathrm{O}_{3}{ }^{2-}, \mathrm{HPO}_{4}{ }^{2-} \\
\mathrm{PO}_{4}{ }^{3-}\end{array}$ & & \\
\hline \multirow{3}{*}{$\mathrm{Fe}^{3+}$} & P-aminobenzoic acid & $\begin{array}{c}\text { LOD: } 5.83 \mu \mathrm{M} \text {, } \\
\text { linear range: } \\
\text { 10-400 } \mu \mathrm{M}\end{array}$ & $\begin{array}{c}\mathrm{Na}^{+}, \mathrm{K}^{+}, \mathrm{Mg}^{2+} \\
\mathrm{Mn}^{2+}, \mathrm{Fe}^{2+}, \mathrm{Co}^{2+} \\
\mathrm{Ni}^{2+}, \mathrm{Cu}^{2+}, \mathrm{Zn}^{2+} \\
\mathrm{Cd}^{2+}, \mathrm{Hg}^{2+}, \mathrm{Al}^{3+} \\
\mathrm{Pb}^{2+}\end{array}$ & $\begin{array}{l}\text { Aggregation- } \\
\text { based }\end{array}$ & $(252)$ \\
\hline & Thiourea & $\begin{array}{l}\text { LOD: } 0.85 \mu \mathrm{M} \text {, } \\
\text { linear range: } 1.0 \\
\text { to } 37 \mu \mathrm{M}\end{array}$ & $\begin{array}{c}\mathrm{Na}^{+}, \mathrm{K}^{+}, \mathrm{Mg}^{2+} \\
\mathrm{Ca}^{2+}, \mathrm{Mn}^{2+}, \mathrm{Co}^{2+} \\
\mathrm{Ni}^{2+}, \mathrm{Cu}^{2+}, \mathrm{Ag}^{+} \\
\mathrm{Zn}^{2+}, \mathrm{Al}^{3+}, \mathrm{Ge}^{4+} \\
\mathrm{Sn}^{2+}, \mathrm{Pb}^{2+}, \mathrm{Ce}^{3+}\end{array}$ & $\begin{array}{c}\text { Etching- } \\
\text { based }\end{array}$ & $(253)$ \\
\hline & Acetyl salicylic acid (ASA) & $\begin{array}{c}\text { LOD: } 0.051 \mu \mathrm{M} \text {, } \\
\text { linear range: } 0.3- \\
2.1 \mu \mathrm{M}\end{array}$ & $\begin{array}{l}\mathrm{Cr}^{3+}, \mathrm{Fe}^{2+}, \mathrm{Co}^{2+} \\
\mathrm{Ni}^{2+}, \mathrm{Zn}^{2+}, \mathrm{Cd}^{2+} \\
\mathrm{Hg}^{2+}, \mathrm{Pb}^{2+}, \mathrm{As}^{3+}\end{array}$ & $\begin{array}{c}\text { Aggregation- } \\
\text { based }\end{array}$ & $(254)$ \\
\hline
\end{tabular}


Table 3. Summary of colorimetric Au/Ag NPs system for ion sensing.

\begin{tabular}{|c|c|c|c|c|c|}
\hline $\mathrm{Zn}^{2+}$ & Sodium borohydride & $\begin{array}{l}\text { LOD: } 0.36 \mu \mathrm{M} \text {, } \\
\text { linear range: 0- } \\
7.6 \mu \mathrm{M}\end{array}$ & $\begin{array}{c}\mathrm{Li}^{+}, \mathrm{Na}^{+}, \mathrm{Mg}^{2+} \\
\mathrm{Ca}^{2+}, \mathrm{Ba}^{2+}, \mathrm{Ti}^{4+} \\
\mathrm{Cr}^{3+}, \mathrm{Mn}^{2+}, \mathrm{Fe}^{3+} \\
\mathrm{Cu}^{2+}, \mathrm{Cd}^{2+}, \mathrm{Hg}^{2+} \\
\mathrm{Ga}^{2+}, \mathrm{Ge}^{2+}, \mathrm{Pb}^{2+} \\
\mathrm{As}^{3+}, \mathrm{F}^{-}, \mathrm{Cl}^{-}, \mathrm{Br}^{-} \\
\mathrm{I}^{-}, \mathrm{NO}_{2}-\mathrm{NO}_{3}^{-} \\
\mathrm{SO}_{4}{ }^{2-}, \mathrm{PO}_{4}^{3-}\end{array}$ & $\begin{array}{l}\text { Aggregation- } \\
\text { based }\end{array}$ & $(255)$ \\
\hline \multirow[b]{2}{*}{$\mathrm{Al}^{3+}$} & $\begin{array}{c}\text { Schiff base obtained from 2-hydroxy 1- } \\
\text { naphthaldehyde and 2- } \\
\text { aminoethanethiol }\end{array}$ & $\begin{array}{l}\text { LOD: } 0.29 \mu \mathrm{M} \text {, } \\
\text { linear range: 9-23 } \\
\mu \mathrm{M}\end{array}$ & $\begin{array}{c}\mathrm{Mg}^{2+}, \mathrm{Ba}^{2+}, \mathrm{Cr}^{3+} \\
\mathrm{Mn}^{2+}, \mathrm{Fe}^{3+}, \mathrm{Co}^{2+} \\
\mathrm{Ni}^{2+}, \mathrm{Cu}^{2+}, \mathrm{Ag}^{+} \\
\mathrm{Zn}^{2+}, \mathrm{Cd}^{2+}, \mathrm{Hg}^{2+} \\
\mathrm{Pb}^{2+}\end{array}$ & $\begin{array}{l}\text { Aggregation- } \\
\text { based }\end{array}$ & $(256)$ \\
\hline & Ascorbic acid & $\begin{array}{l}\text { LOD: } 12.5 \text { ppb, } \\
\text { linear range: } \\
\text { 100-350 ppb }\end{array}$ & $\begin{array}{c}\mathrm{Li}^{+}, \mathrm{Mn}^{2+}, \mathrm{Fe}^{3+} \\
\mathrm{Co}^{3+}, \mathrm{Ni}^{2+}, \mathrm{Zn}^{2+} \\
\mathrm{Hg}^{2+}, \mathrm{Sn}^{2+}, \mathrm{Pb}^{2+} \\
\mathrm{F}^{-}, \mathrm{Cl}^{-}, \mathrm{Br}^{-}, \mathrm{I}^{-} \\
\mathrm{NO}_{3}, \mathrm{SO}_{4}{ }^{2-} \\
\mathrm{PO}_{4}{ }^{3-}\end{array}$ & $\begin{array}{l}\text { Aggregation- } \\
\text { based }\end{array}$ & (257) \\
\hline
\end{tabular}




\begin{tabular}{|c|c|c|c|c|c|}
\hline & Mentha & $\begin{array}{c}\text { LOD: } 1 \mathrm{nM} \text {, linear } \\
\text { range: } 0.1-200 \\
\mathrm{nM}\end{array}$ & $\begin{array}{c}\mathrm{Ca}^{2+}, \mathrm{Cr}^{3+}, \mathrm{Cr}^{6+}, \\
\mathrm{Mn}^{2+}, \mathrm{Fe}^{3+}, \mathrm{Co}^{2+} \\
\mathrm{Ni}^{2+}, \mathrm{Cu}^{2+}, \mathrm{Zn}^{2} \\
\mathrm{Cd}^{2+}, \mathrm{Hg}^{2+}, \mathrm{Al}^{3+} \\
\mathrm{Pb}^{2+}\end{array}$ & $\begin{array}{l}\text { Aggregation- } \\
\text { based }\end{array}$ & $(258)$ \\
\hline & DA & $\begin{array}{c}\text { LOD: } 0.81 \mu \mathrm{M} \text {, } \\
\text { linear range: } 1- \\
3.5 \mu \mathrm{M}\end{array}$ & $\begin{array}{c}\mathrm{Mg}^{2+}, \mathrm{Ca}^{2+}, \mathrm{Ba}^{2+} \\
\mathrm{Cr}^{3+}, \mathrm{Mn}^{2+}, \mathrm{Fe}^{2+} \\
\mathrm{Fe}^{3+}, \mathrm{Co}^{2+}, \mathrm{Ni}^{2+} \\
\mathrm{Cu}^{2+}, \mathrm{Ag}^{+}, \mathrm{Zn}^{2} \\
\mathrm{Cd}^{2+}, \mathrm{Hg}^{2+}, \mathrm{Pb}^{2+}\end{array}$ & $\begin{array}{l}\text { Aggregation- } \\
\text { based }\end{array}$ & (259) \\
\hline $\mathrm{Al}^{3+}$ and $\mathrm{F}^{-}$ & Polyacrylate & $\begin{array}{l}\text { LOD: } 2 \mu \mathrm{M} \text { and } \\
18 \mu \mathrm{M} \text {, linear } \\
\text { range: } 50-150 \\
\mu \mathrm{M} \text { and } 30-200 \\
\mu \mathrm{M}\end{array}$ & $\begin{array}{l}\mathrm{Mg}^{2+}, \mathrm{Ca}^{2+}, \mathrm{Sr}^{2+} \\
\mathrm{Ba}^{2+}, \mathrm{Cr}^{3+}, \mathrm{Fe}^{3+} \\
\mathrm{Co}^{2+}, \mathrm{Ni}^{2+}, \mathrm{Cu}^{2+} \\
\mathrm{Zn}^{2+}, \mathrm{Cd}^{2+}, \mathrm{Hg}^{2+}, \\
\mathrm{Al}^{3+}, \mathrm{Pb}^{2+}, \mathrm{F}^{-}, \mathrm{Cl}^{-}, \\
\mathrm{Br}^{-}, \mathrm{I}^{-}, \mathrm{CN}^{-}, \mathrm{SO}_{4}^{2-} \\
\mathrm{AcO}^{-}, \mathrm{NO}_{3}{ }^{-}, \mathrm{NO}_{2} \\
\quad \mathrm{SCN}^{-}, \mathrm{N}_{3}^{-}\end{array}$ & $\begin{array}{c}\text { Aggregation- } \\
\text { based }\end{array}$ & $(260)$ \\
\hline
\end{tabular}




\begin{tabular}{|c|c|c|c|c|c|}
\hline & & & $\begin{array}{c}{\left[\mathrm{Cr}_{2} \mathrm{O}_{7}\right]^{2-}, \mathrm{PCl}_{3}^{-}} \\
\mathrm{H}_{2} \mathrm{PO}_{4}^{-}\end{array}$ & & \\
\hline $\begin{array}{c}\mathrm{M}^{3+}\left(\mathrm{Al}^{3+}, \mathrm{Cr}^{3+}\right. \\
\left.\mathrm{Fe}^{3+}\right)\end{array}$ & $\begin{array}{l}\text { 1:1 ratio of sodium } 10- \\
\text { mercaptodecanesulfonic acid and (10- } \\
\text { mercaptodecyl) trimethylammonium } \\
\text { bromide }\end{array}$ & $\begin{array}{c}\text { LOD: } 2 \mu \mathrm{M} \\
\left(\mathrm{Fe}^{3+}\right), 10 \mu \mathrm{M} \\
\left(\mathrm{Al}^{3+}\right) \text { and } 18 \mu \mathrm{M} \\
\left(\mathrm{Cr}^{3+}\right) \text {, linear } \\
\text { range: } 1-50 \mu \mathrm{M} \\
\left(\mathrm{Fe}^{3+}\right)\end{array}$ & $\begin{array}{c}\mathrm{Na}^{+}, \mathrm{K}^{+}, \mathrm{Mg}^{2+} \\
\mathrm{Ca}^{2+}, \mathrm{Ba}^{2+}, \mathrm{Fe}^{2+} \\
\mathrm{Co}^{2+}, \mathrm{Cu}^{2+}, \mathrm{Ag}^{+} \\
\mathrm{Zn}^{2+}, \mathrm{Cd}^{2+}, \mathrm{Hg}^{2+} \\
\mathrm{Sn}^{2+}, \mathrm{Pb}^{2+}\end{array}$ & $\begin{array}{l}\text { Aggregation- } \\
\text { based }\end{array}$ & $(261)$ \\
\hline $\mathrm{NO}_{2}^{-}$ & 4-aminobenzenthiol, (4-ABT) & $\begin{array}{l}\text { LOD: } 10.8 \mu \mathrm{M} \text {, } \\
\text { linear range: } \\
5.42-174 \mu \mathrm{M}\end{array}$ & $\begin{array}{c}\mathrm{F}^{-}, \mathrm{Br}^{-}, \mathrm{CO}_{3}{ }^{2-} \\
\mathrm{HCO}_{3}^{-}, \mathrm{CH}_{3} \mathrm{COO}^{-} \\
\mathrm{C}_{2} \mathrm{O}_{4}{ }^{2-}, \mathrm{HPO}_{4}{ }^{2-} \\
\mathrm{H}_{2} \mathrm{PO}_{4}^{-}, \mathrm{SO}_{4}{ }^{2-} \\
\mathrm{NO}_{3}{ }^{-}\end{array}$ & $\begin{array}{l}\text { Aggregation- } \\
\text { based }\end{array}$ & $(262)$ \\
\hline $\mathbf{F}^{-}$ & $\begin{array}{c}\mathrm{N}, \mathrm{N} \text { '-Bis(4-[tert- } \\
\text { butyl(dimethyl)silyloxy]benzyl(4- } \\
\text { phenyl)sulfane)-3,6,9- } \\
\text { trioxaundecanedicarboxamide }\end{array}$ & $\begin{array}{c}\text { LOD: } 120 \mu \mathrm{M} \text {, } \\
\text { linear range: } 120 \\
\mu \mathrm{M}-1.5 \mathrm{mM}\end{array}$ & $\begin{array}{c}\mathrm{Cl}^{-}, \mathrm{Br}^{-}, \mathrm{I}^{-} \\
\mathrm{CH}_{3} \mathrm{COO}^{-} \\
\mathrm{HPO}_{4}{ }^{2-}, \mathrm{H}_{2} \mathrm{PO}_{4}^{-}, \\
\mathrm{SO}_{4}^{2-}, \mathrm{NO}_{3}^{-}, \mathrm{CN}^{-}, \\
\mathrm{N}_{3}^{-}\end{array}$ & $\begin{array}{l}\text { Aggregation- } \\
\text { based }\end{array}$ & $(263)$ \\
\hline
\end{tabular}


Table 3. Summary of colorimetric Au/Ag NPs system for ion sensing.

\begin{tabular}{|c|c|c|c|c|c|}
\hline & 3-aminopropyltrimethoxysilane & $\begin{array}{l}\text { LOD: } 0.45 \mu \mathrm{M} \text {, } \\
\text { linear range: } 0.5- \\
\quad 7 \mu \mathrm{M}\end{array}$ & $\begin{array}{c}\mathrm{Cl}^{-}, \mathrm{Br}^{-}, \mathrm{I}^{-}, \mathrm{SCN}^{-} \\
\mathrm{BO}_{3}^{3-}, \mathrm{Ac}^{-}, \mathrm{NO}_{3}^{-} \\
\mathrm{CO}_{3}{ }^{2-}, \mathrm{PO}_{4}^{3-} \\
\mathrm{SO}_{4}{ }^{2-}\end{array}$ & $\begin{array}{l}\text { Aggregation- } \\
\text { based }\end{array}$ & $(264)$ \\
\hline & 2-thiobarbituric acid (TBA) & $\begin{array}{l}\text { LOD: } 10 \mathrm{mM} \text {, } \\
\text { linear range: 1-20 } \\
\text { mM }\end{array}$ & $\begin{array}{c}\mathrm{Cl}^{-}, \mathrm{Br}^{-}, \mathrm{I}^{-} \\
\mathrm{CH}_{3} \mathrm{COO}^{-}, \mathrm{NO}_{3}^{-} \\
\mathrm{CO}_{3}{ }^{2-}, \mathrm{H}_{2} \mathrm{PO}_{4}^{-}\end{array}$ & $\begin{array}{l}\text { Aggregation- } \\
\text { based }\end{array}$ & $(265)$ \\
\hline $\mathrm{CN}^{-}$ & $\begin{array}{c}\text { Fluorescein isothiocyanate (FITC) } \\
\text { polysorbate20 (PS 20) }\end{array}$ & $\begin{array}{l}\text { LOD: } 150 \mu \mathrm{M} \text {, } \\
\text { linear range: } \\
150-300 \mu \mathrm{M}\end{array}$ & $\begin{array}{c}\mathrm{Li}^{+}, \mathrm{K}^{+}, \mathrm{Mg}^{2+}, \\
\mathrm{Ca}^{2+}, \mathrm{Cr}^{3+}, \mathrm{Mn}^{2+}, \\
\mathrm{Fe}^{2+}, \mathrm{Co}^{2+}, \mathrm{Ni}^{2+}, \\
\mathrm{Cu}^{2+}, \mathrm{Zn}^{2+}, \mathrm{Cd}^{2+}, \\
\mathrm{Hg}^{2+}, \mathrm{Pb}^{2+}, \mathrm{F}^{-}, \mathrm{Cl}^{-} \\
, \mathrm{Br}^{-}, \mathrm{BrO}_{3}^{3-}, \mathrm{NO}_{3}^{-} \\
, \mathrm{SO}_{4}{ }^{2-}, \mathrm{ClO}_{4}, \\
\mathrm{CO}_{3}{ }^{2-}, \mathrm{PO}_{4}{ }^{3-} \\
, \mathrm{C}_{6} \mathrm{H}_{5} \mathrm{O}_{7}{ }^{3-}, \mathrm{SO}_{3}{ }^{2-}, \\
\mathrm{S}_{2} \mathrm{O}_{8}{ }^{2-}, \mathrm{CH}_{3} \mathrm{COO}^{-}\end{array}$ & $\begin{array}{c}\text { Aggregation- } \\
\text { based }\end{array}$ & (266) \\
\hline
\end{tabular}


Table 3. Summary of colorimetric Au/Ag NPs system for ion sensing.

\begin{tabular}{|c|c|c|c|c|c|}
\hline & Polysorbate 40 (PS 40) & $\begin{array}{l}\text { LOD: } 0.16 \mu \mathrm{M} \text {, } \\
\text { linear range: } 0.4- \\
\quad 32 \mu \mathrm{M}\end{array}$ & $\begin{array}{c}\mathrm{Na}^{+}, \mathrm{K}^{+}, \mathrm{Mg}^{2+} \\
\mathrm{Ca}^{2+}, \mathrm{Ba}^{2+}, \mathrm{Mn}^{2+}, \\
\mathrm{Fe}^{2+}, \mathrm{Co}^{2+}, \mathrm{Cu}^{2+}, \\
\mathrm{Zn}^{2+}, \mathrm{Cd}^{2+}, \mathrm{Hg}^{2+}, \\
\mathrm{Al}^{3+}, \mathrm{Sn}^{2+}, \mathrm{F}^{-}, \mathrm{Cl}^{-}, \\
\mathrm{Br}^{-}, \mathrm{I}^{-}, \mathrm{BrO}_{3}^{3-} \\
\mathrm{NO}_{3}^{-}, \mathrm{NO}_{2}^{-}, \mathrm{AcO}^{-}, \\
\mathrm{SO}_{4}^{2-}, \mathrm{ClO}_{4}^{-}, \\
\mathrm{CO}_{3}^{2-}, \mathrm{HCO}_{3}^{-}, \\
\mathrm{PO}_{4}^{3-}, \mathrm{SO}_{3}^{2-}, \mathrm{IO}_{3}^{-}, \\
\mathrm{BO}_{3}^{-}\end{array}$ & $\begin{array}{c}\text { Etching- } \\
\text { based }\end{array}$ & $(267)$ \\
\hline $\mathrm{OCI}^{-}$ & DTT & $\begin{array}{l}\text { LOD: } 2 \mu \mathrm{M} \text {, } \\
\text { linear range: 0- } \\
7 \mu \mathrm{M}\end{array}$ & $\begin{array}{c}\mathrm{Mg}^{2+}, \mathrm{Ca}^{2+} \\
\mathrm{Mn}^{2+}, \mathrm{Fe}^{3+} \\
\mathrm{Cu}^{2+}, \mathrm{Al}^{3+}, \mathrm{Pb}^{2} \\
\mathrm{~F}^{-}, \mathrm{Cl}^{-}, \mathrm{Br}^{-}, \mathrm{NO}_{3}- \\
\mathrm{SO}_{4}{ }^{2-}, \mathrm{CO}_{3}{ }^{2-}\end{array}$ & $\begin{array}{l}\text { Aggregation- } \\
\text { based }\end{array}$ & (268) \\
\hline $\mathbf{I}^{-}$ & $\begin{array}{l}\mathrm{N}-([1-(2-a m i n o-2-o x o e t h y l)-1 \mathrm{H}-1,2,3- \\
\text { triazol-4-yl]methyl)-5-(1,2-dithiolan-3- } \\
\text { yl) pentanamide }\end{array}$ & $\begin{array}{l}\text { LOD: } 15 \mathrm{nM} \text {, } \\
\text { linear range: } 0.5- \\
\quad 6 \mu \mathrm{M}\end{array}$ & $\begin{array}{c}\mathrm{F}^{-}, \mathrm{Cl}^{-}, \mathrm{Br}^{-}, \mathrm{CN}^{-}, \\
\mathrm{ClO}_{4}^{-}, \mathrm{HSO}_{4}^{-} \\
\mathrm{H}_{2} \mathrm{PO}_{4}^{-}, \mathrm{HPO}_{4}^{-2} \\
\mathrm{NO}_{3}^{-}, \mathrm{AcO}^{-}, \mathrm{OH}^{-},\end{array}$ & $\begin{array}{l}\text { Aggregation- } \\
\text { based }\end{array}$ & (269) \\
\hline
\end{tabular}




\begin{tabular}{|c|c|c|c|c|c|}
\hline & & & $\begin{array}{l}\text { pyrophosphate } \\
(\mathrm{PPi}), \mathrm{S}^{2-}, \mathrm{S}_{2} \mathrm{O}_{3}{ }^{2-} \\
\mathrm{SCN}^{-}\end{array}$ & & \\
\hline $\mathrm{SO}_{3}{ }^{2-}$ & $\begin{array}{l}\text { 4-cyanobenzene diazonium } \\
\text { tetrafluoroborate (4-CBD) }\end{array}$ & $\begin{array}{c}\text { LOD: } 2 \mu \mathrm{M} \text {, } \\
\text { linear range: } 2- \\
10 \mu \mathrm{M}\end{array}$ & $\begin{array}{c}\mathrm{K}^{+}, \mathrm{Ca}^{2+}, \mathrm{Sr}^{2+}, \\
\mathrm{Mn}^{2+}, \mathrm{Fe}^{3+}, \mathrm{Ni}^{2+}, \\
\mathrm{Cu}^{2+}, \mathrm{Ag}^{+}, \mathrm{Cd}^{2+}, \\
\mathrm{Hg}^{2+}, \mathrm{Pb}^{2+}, \mathrm{F}^{-} \\
\mathrm{Cl}^{-}, \mathrm{Br}^{-}, \mathrm{I}^{-}, \mathrm{NO}_{3}- \\
\mathrm{CH}_{3} \mathrm{COO}^{-}, \mathrm{CO}_{3}^{2-} \\
\mathrm{SCN}^{-}, \mathrm{P}_{2} \mathrm{O}_{7}^{4-} \\
\mathrm{SO}_{4}{ }^{2-}\end{array}$ & $\begin{array}{l}\text { Aggregation- } \\
\text { based }\end{array}$ & $(270)$ \\
\hline $\mathbf{S}^{2-}$ & $\begin{array}{l}\text { 2,2'-azino-bis(3-ethyl-benzothiazoline- } \\
\text { 6-sulfonic acid) (ABTS) }\end{array}$ & $\begin{array}{l}\text { LOD: } 0.28 \mu \mathrm{M} \text {, } \\
\text { linear range: } 0.5- \\
15 \mu \mathrm{M}\end{array}$ & $\begin{array}{c}\mathrm{F}^{-}, \mathrm{Cl}^{-}, \mathrm{Br}^{-}, \mathrm{I}^{-} \\
\mathrm{NO}_{3}^{-}, \mathrm{CO}_{3}^{2-} \\
\mathrm{SO}_{4}^{2}, \mathrm{ClO}_{4}^{-}, \mathrm{BrO}_{3}^{-} \\
\mathrm{NO}_{2}^{-}, \mathrm{PO}_{4}^{3-} \\
\mathrm{SO}_{3}{ }^{2-}, \mathrm{Ac}^{-}\end{array}$ & $\begin{array}{l}\text { Growth- } \\
\text { based }\end{array}$ & (180) \\
\hline $\mathrm{SO}_{4}{ }^{2-}$ & Cys & $\begin{array}{c}\text { LOD: } 0.16 \mu \mathrm{M} \text {, } \\
\text { linear range: } \\
0.2-4 \mu \mathrm{M}\end{array}$ & $\begin{array}{c}\mathrm{Na}^{+}, \mathrm{K}^{+}, \mathrm{Mg}^{2+} \\
\mathrm{Ca}^{2+}, \mathrm{Mn}^{2+} \\
\mathrm{Co}^{2+}, \mathrm{Ni}^{2+}, \mathrm{Cu}^{2+}\end{array}$ & $\begin{array}{l}\text { Aggregation- } \\
\text { based }\end{array}$ & $(271)$ \\
\hline
\end{tabular}


Table 3. Summary of colorimetric Au/Ag NPs system for ion sensing.

$$
\begin{gathered}
\mathrm{Zn}^{2+}, \mathrm{Al}^{3+}, \mathrm{Pb}^{2+}, \\
\mathrm{F}^{-}, \mathrm{Cl}^{-}, \mathrm{Br}^{-}, \mathrm{NO}_{3}- \\
\mathrm{CO}_{3}{ }^{2-}, \mathrm{SO}_{4}^{2-}, \mathrm{S}^{2-} \\
\mathrm{S}_{2} \mathrm{O}_{3}^{2-}, \mathrm{BrO}_{3}^{-} \\
\mathrm{PO}_{4}{ }^{3-}, \mathrm{ClO}_{3}^{-},
\end{gathered}
$$




\subsubsection{Colorimetric small organic molecules sensors}

In addition to inorganic ions, the same principle of detection can be also applied for sensing different organic molecules such as melamine, phenols, bisphenol-A, antibiotics, pesticides and drugs (see Table 2).(272)

Metal NPs stabilized with different capping agents have proven to be effective colorimetric sensors for melamine. Among others, 1-(2-mercaptoethyl)-1,2,3,4,5,6hexanhydro-s-triazine-2,4,6-trione (MTT),(273) rutin and curcumin,(274) and gallic acid (181) can act as a linker of melamine molecules triggering the NPs assembly and hence a colour change from yellow to brown.

Wangoo and co-workers proposed a straightforward colorimetric sensing strategy of the insecticide malathion based on the use of aptamer specific of malathion and a positive polyelectrolyte; polydiallyldimethylammonium chloride (PDDA) (see Figure 19).(275) When no malathion is present, PDDA is free to associate with the aptamer and hence when this mixture is added to the AuNPs solution its stability is not comprised. Conversely, when malathion is present then aptamer will be complex to it and hence the PDDA will be free to trigger the AuNPs aggregation.

Mao and co-workers developed a strategy to detect methamphetamine and cocaine through a non-aggregated Au@Ag core@shell NPs methodology. $(276,277)$ For this purpose they have employed a three component system: I) An aptamer which is specific for cocaine or methamphetamine II) Au@Ag NPs stabilized with a DNA sequence partially complementary to the aptamer, and III) magnetic beads conjugated with another DNA sequence partially complementary to the aptamer sequence. The NPs assembly is triggered by the mixture of the three components through a DNADNA hybridization, forming a sandwich structure. However, due to the higher affinity of DNA aptamers with illicit drugs, the sandwich structure can be disassembled when illicit drugs are introduced into the solution. This process leads to the recovery of the initial absorbance of the individual Au@Ag NPs which is proportional to the concentrations of the illicit drugs.

Other examples of plasmonic colorimetric sensors of small molecules can be found in Table 4. 
A
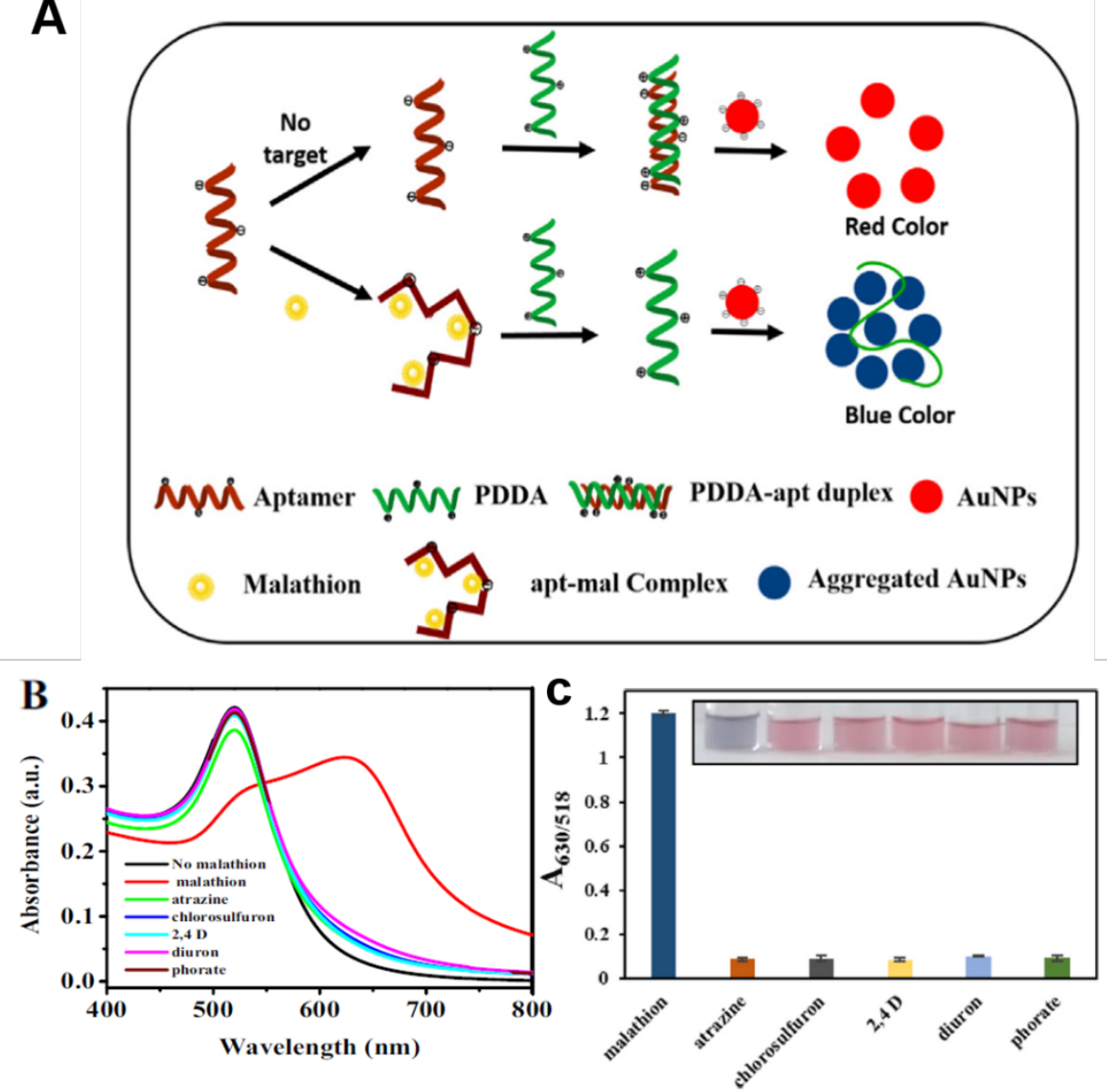

Figure 19. (a) Schematic illustration of a colorimetric aptasensor based on gold nanoparticles for the detection of malathion. In the absence of malathion, the aptamer interacts only with the polymer and hence, the gold nanoparticles are well dispersed due to lack of sufficient amount of PDDA. However, in the presence of malathion, the aptamer interacts with the malathion and free PDDA aggregate the AuNPs, thereby leading to the colour change of the solution from red to blue. (b-c) Selectivity of the assay for the detection of malathion. (b) The absorbance spectra of AuNPs with various pesticides. The concentration of all pesticides, PDDA and aptamer was $2 \mu \mathrm{M}, 15 \mathrm{nM}$ and $50 \mathrm{nM}$, respectively. (c) relative response of the aptasensor on treatment with different pesticides. Inset shows the corresponding images. Adapted from reference (275) with permission of Elsevier. 
Table 4. Summary of colorimetric Au/Ag NPs system for small molecules sensing.

\begin{tabular}{|c|c|c|c|c|c|}
\hline Molecule & $\begin{array}{l}\text { Receptor } \\
\text { molecules }\end{array}$ & Sensitivity & Interferences & $\begin{array}{l}\text { Type of } \\
\text { colorimetric } \\
\text { detection }\end{array}$ & Reference \\
\hline \multirow{3}{*}{$\begin{array}{l}\text { Melamine } \\
\text { (toxic compound) }\end{array}$} & $\begin{array}{c}3,3^{\prime}, 5,5^{\prime}- \\
\text { tetramethlybenzidine } \\
(\mathrm{TMB})-\mathrm{H}_{2} \mathrm{O}_{2} \\
\text { chromogenic } \\
\text { reaction }\end{array}$ & $\begin{array}{l}\text { LOD: } 0.2 \mathrm{nM} \text {, } \\
\text { linear range: } \\
0.001-0.8 \mu \mathrm{M}\end{array}$ & $\begin{array}{c}\text { Thymine, Lys, Glycine (Gly), } \\
\text { Glucose, vitamin C, Cys, } \mathrm{Zn}^{2+} \\
\mathrm{K}^{+}, \mathrm{Ca}^{2+}\end{array}$ & $\begin{array}{l}\text { Enzyme- } \\
\text { mimetic- } \\
\text { based }\end{array}$ & $(278)$ \\
\hline & MTT & $\begin{array}{l}\text { LOD: } 2 \mu \mathrm{M} \text {, } \\
\text { linear range: } \\
2-14 \mu \mathrm{M}\end{array}$ & Cytosine, Uracil and Thymine & $\begin{array}{l}\text { Aggregation- } \\
\text { based }\end{array}$ & $(273)$ \\
\hline & Rutin and Curcumin & $\begin{array}{c}\text { LOD: } 0.01 \\
\text { ppm (79 nM) } \\
\text { and } 0.24 \mathrm{ppm} \\
\text { (1900 nM), } \\
\text { linear range: } \\
0.05-0.4 \mathrm{ppm} \\
\text { and } 1-4 \mathrm{ppm}\end{array}$ & $\begin{array}{l}\text { Urea, Nitrate, Leucine (Leu), } \\
\text { Sucrose, } \mathrm{Na}^{+} \text {, Glucose, } \mathrm{Cl}^{-}, \mathrm{K}^{+}\end{array}$ & $\begin{array}{l}\text { Aggregation- } \\
\text { based }\end{array}$ & $(274)$ \\
\hline
\end{tabular}




\begin{tabular}{|c|c|c|c|c|c|}
\hline & Gallic acid & $\begin{array}{l}\text { LOD: } 3.609 \\
\text { nM, linear } \\
\text { range: } 0.04- \\
20 \mu \mathrm{M}\end{array}$ & $\begin{array}{l}\text { Vitamin B6, L-Trp, L-Tyrosine } \\
\text { (Tyr), L-Val, L-Serine (Ser), L- } \\
\text { isoleucine, L-Phenylalanine } \\
\text { (Phe), L-Alanine (Ala), Gly, L- } \\
\text { Leu, urea, L-Arginine (Arg) }\end{array}$ & $\begin{array}{l}\text { Growth- } \\
\text { based }\end{array}$ & (181) \\
\hline $\begin{array}{c}\text { Bisphenol A (toxic } \\
\text { compound) }\end{array}$ & $\begin{array}{c}\text { Aptamer and } \\
\text { cationic polymer }\end{array}$ & $\begin{array}{l}\text { LOD: } 1.50 \\
\text { nM, linear } \\
\text { range: } 1.50- \\
500 \mathrm{nM}\end{array}$ & $\begin{array}{c}\text { Diethylstilbestrol (DES), } \\
\text { dichlorodiphenyltrichloroethane } \\
\text { (o,p'-DDT), 17ß-estradiol (E2), } \\
\text { progesterone (PRG), } \\
\text { thiamphenicol(THI), 7- } \\
\text { aminocephalosporanic acid (7- } \\
\text { ACA), kanamycin (Kana), Gly, } \\
\text { Cys, L-ascorbic acid, } \\
\text { Ampicillin (AMP), dimethyl } \\
\text { sulfoxide (DMSO), Cd }{ }^{2+}, \mathrm{Cu}^{2+}\end{array}$ & $\begin{array}{l}\text { Aggregation- } \\
\text { based }\end{array}$ & (279) \\
\hline $\begin{array}{l}\text { Phenols (toxic } \\
\text { compound) }\end{array}$ & $\begin{array}{c}\text { single-stranded DNA } \\
\text { (ssDNA) }\end{array}$ & $\begin{array}{l}\text { LOD: } 0.11 \mu \mathrm{M} \\
\text { for catechol } \\
\text { and } 1.6 \mu \mathrm{M} \\
\text { for } \\
\text { hydroquinone, }\end{array}$ & $\begin{array}{c}\mathrm{Mg}^{2+}, \mathrm{Zn}^{2+}, \mathrm{Fe}^{3+}, \mathrm{Mn}^{2+}, \mathrm{Cd}^{2+} \\
\mathrm{Cu}^{2+}, \mathrm{Ag}^{+}, \mathrm{Co}^{2+}, \mathrm{Lys}, \mathrm{Ala}, \mathrm{Val} \\
\text { Gly, Threonine (Thr) and Citric } \\
\text { acid }\end{array}$ & $\begin{array}{l}\text { Aggregation- } \\
\text { based }\end{array}$ & $(280)$ \\
\hline
\end{tabular}




\begin{tabular}{|c|c|c|c|c|c|}
\hline & & $\begin{array}{c}\text { linear range: } \\
0.2-7.0 \mu \mathrm{M} \\
\text { for catechol } \\
\text { and } 2.7-19 \\
\mu \mathrm{M} \text { for } \\
\text { hydroquinone }\end{array}$ & & & \\
\hline $\begin{array}{c}\text { Poly- and } \\
\text { perfluoroalkyl } \\
\text { substances } \\
\text { (PFASs) }\end{array}$ & $\begin{array}{l}\text { Poly(ethylene glycol)- } \\
\text { terminated (PEG- } \\
\text { thiols) and } \\
\text { perfluoroalkyl- } \\
\text { terminated (F-thiols) } \\
\text { alkane-thiols }\end{array}$ & $\begin{array}{l}\text { LOD: (11-24 } \\
\text { nM), linear } \\
\text { range: } \sim(0.01- \\
\text { 35) } \mu \mathrm{M}\end{array}$ & $\mathrm{Na}^{+}, \mathrm{Mg}^{2+}, \mathrm{Ca}^{2+}$ & $\begin{array}{l}\text { Aggregation- } \\
\text { based }\end{array}$ & (281) \\
\hline $\begin{array}{l}\text { Kanamycin } \\
\text { (antibiotic) }\end{array}$ & $\begin{array}{l}\text { 4-amino-3- } \\
\text { hydrazino-5- } \\
\text { mercapto-1, 2, 4- } \\
\text { triazole (AHMT) }\end{array}$ & $\begin{array}{l}\text { LOD: } 0.004 \\
\mu \mathrm{M}, \text { linear } \\
\text { range: } 0.005- \\
0.1 \mu \mathrm{M} \text { and } \\
0.1-20 \mu \mathrm{M}\end{array}$ & $\begin{array}{l}\text { Tetracycline, L-arg, L -aspartic } \\
\text { acid, Glucose, GSH, Gly, L- } \\
\text { Cys, and L -Phe, } \mathrm{Na}^{+}, \mathrm{K}^{+} \\
\mathrm{Mg}^{2+}, \mathrm{Ca}^{2+}\end{array}$ & $\begin{array}{l}\text { Aggregation- } \\
\text { based }\end{array}$ & (282) \\
\hline
\end{tabular}




\begin{tabular}{|c|c|c|c|c|c|}
\hline $\begin{array}{l}\text { Pendimethalin } \\
\text { (herbicide) }\end{array}$ & $\begin{array}{l}\text { Ractopamine- } \\
\text { dithiocarbamate }\end{array}$ & $\begin{array}{c}\text { LOD: } 0.22 \mu \mathrm{M} \\
\text {, linear range: } \\
5-500 \mu \mathrm{M}\end{array}$ & $\begin{array}{c}\text { Other pesticides (insecticides } \\
\text { and fungicides) such as } \\
\text { acephate, acetamiprid, } \\
\text { buprofezin, cypermethrin, } \\
\text { chlorpyrifos, fenvalerate, } \\
\text { imidacloprid, quinalphos, } \\
\text { carbendazim, cymoxanil, } \\
\text { hexaconazole, mancozeb, } \\
\text { metalaxyl and propiconazol, } \\
\mathrm{Metal}^{2} \text { ions }\left(\mathrm{Na}^{+}, \mathrm{K}^{+}, \mathrm{Mg}^{2+},\right. \\
\mathrm{Ca}^{2+}, \mathrm{Ba}^{2+}, \mathrm{Cr}^{3+}, \mathrm{Mn}^{2+}, \mathrm{Fe}^{2+}, \\
\mathrm{Fe}^{3+}, \mathrm{Co}^{2+}, \mathrm{Ni}^{2+}, \mathrm{Cu}^{2+}, \mathrm{Zn}^{2+}, \\
\mathrm{Cd}^{2+}, \mathrm{Hg}^{2+}, \mathrm{Al}^{3+}{\left.\text { and } \mathrm{Pb}^{2+},\right)}^{-} \\
\mathrm{Anions} \mathrm{Cl}^{-}, \mathrm{I}^{-}, \mathrm{Br}^{-}, \mathrm{NO}_{3}{ }^{-}, \\
\left.\mathrm{CH}_{3} \mathrm{COO}^{-}, \mathrm{SO}_{4}^{2-}, \mathrm{S}^{2-}, \mathrm{Cr}_{2} \mathrm{O}_{7}^{2-}\right)\end{array}$ & $\begin{array}{l}\text { Aggregation- } \\
\text { based }\end{array}$ & (283) \\
\hline $\begin{array}{c}\text { Metsulfuron- } \\
\text { methyl (herbicide) }\end{array}$ & DTTC-calix[4]arene & $\begin{array}{c}\text { LOD: } 0.19 \mu \mathrm{M} \\
\text {, linear range: } \\
1-50 \mu \mathrm{M}\end{array}$ & $\begin{array}{l}\text { Other pesticides, including } \\
\text { insecticides: (triazophos, } \\
\text { chlorpyrifos, temephos, } \\
\text { quinalphos, cypermethrin, } \\
\text { bifenthrin, buprofezin) and } \\
\text { fungicides (difenoconazole, }\end{array}$ & $\begin{array}{l}\text { Aggregation- } \\
\text { based }\end{array}$ & $(284)$ \\
\hline
\end{tabular}




\begin{tabular}{|c|c|c|c|c|c|}
\hline & & & $\begin{array}{c}\text { hexaconazole, propiconazole, } \\
\text { chlorothalonil and metalaxyl), } \\
\text { Metal ions }\left(\mathrm{Na}^{+}, \mathrm{K}^{+}, \mathrm{Mg}^{2+},\right. \\
\mathrm{Ca}^{2+}, \mathrm{Ba}^{2+}, \mathrm{Cr}^{3+}, \mathrm{Mn}^{2+}, \mathrm{Fe}^{2+}, \\
\mathrm{Fe}^{3+}, \mathrm{Co}^{2+}, \mathrm{Ni}^{2+}, \mathrm{Cu}^{2+}, \mathrm{Zn}^{2+}, \\
\left.\mathrm{Cd}^{2+}, \mathrm{Hg}^{2+}, \mathrm{Al}^{3+} \text { and } \mathrm{Pb}^{2+},\right) \\
\text { Anions }\left(\mathrm{Cl}^{-}, \mathrm{I}^{-}, \mathrm{Br}^{-}, \mathrm{NO}_{3}^{-},\right. \\
\left.\mathrm{CH}_{3} \mathrm{COO}^{-}, \mathrm{SO}_{4}^{2-}, \mathrm{S}^{2-}, \mathrm{Cr}_{2} \mathrm{O}_{7}^{2-}\right)\end{array}$ & & \\
\hline $\begin{array}{c}\text { Organophosphate } \\
\text { (pesticide) }\end{array}$ & $\begin{array}{c}\text { Enzymatic } \\
\text { hydrolysis reaction } \\
\text { of } \\
\text { acetylcholinesterase } \\
\text { and } \mathrm{Au}^{3+}\end{array}$ & $\begin{array}{l}\text { LOD: } 0.7 \mathrm{ppb} \\
(2.4 \mathrm{nM}) \\
\text { linear range: } \\
15 \text { to } 65 \mathrm{ppb} \\
\text { and from } 140 \\
\text { to } 1000 \mathrm{ppb}\end{array}$ & $\begin{array}{l}\mathrm{Na}^{+}, \mathrm{K}^{+}, \mathrm{Mg}^{2+}, \mathrm{Ca}^{2+}, \mathrm{Fe}^{3+} \\
\mathrm{Cu}^{2+}, \mathrm{SO}_{4}^{2-}, \mathrm{CO}_{3}^{2-}, \mathrm{NO}_{3}^{-}\end{array}$ & $\begin{array}{l}\text { Growth- } \\
\text { based }\end{array}$ & $(285)$ \\
\hline $\begin{array}{l}\text { Quinalphos } \\
\text { (pesticide) }\end{array}$ & p-nitroaniline DTTC & $\begin{array}{l}\text { LOD: } 3.21 \mu \mathrm{M} \\
\text {, linear range: } \\
10-1000 \mu \mathrm{M}\end{array}$ & $\begin{array}{c}\text { Acephate, Monocrotophos, } \\
\text { Glyphosate, Chlorpyfos, } \\
\text { Triazophos, Dichlorvos, } \\
\text { Quinalphos }\end{array}$ & $\begin{array}{l}\text { Aggregation- } \\
\text { based }\end{array}$ & $(286)$ \\
\hline
\end{tabular}


Table 4. Summary of colorimetric Au/Ag NPs system for small molecules sensing.

\begin{tabular}{|c|c|c|c|c|c|}
\hline & & LOD: 0.06 & & & \\
\hline $\begin{array}{c}\text { Malathion } \\
\text { (insecticide) }\end{array}$ & $\begin{array}{l}\text { Aptamer and } \\
\text { cationic polymer }\end{array}$ & $\begin{array}{l}\text { pM, linear } \\
\text { range: } 0.5- \\
1000 \text { pM }\end{array}$ & $\begin{array}{l}\text { Atrazine, chlorosulfuron, 2,4 D, } \\
\text { diuron, phorate }\end{array}$ & $\begin{array}{l}\text { Aggregation- } \\
\text { based }\end{array}$ & $(275)$ \\
\hline $\begin{array}{l}\text { Cyhalothrin } \\
\text { (insecticide) }\end{array}$ & $\begin{array}{l}\text { 4-Amino-3- } \\
\text { mercaptobenzoic } \\
\text { acid }\end{array}$ & $\begin{array}{l}\text { LOD: } 0.75 \mu \mathrm{M} \\
\text {, linear range: } \\
0.25 \mu \mathrm{M} \text { to } 0.1 \\
\mathrm{mM}\end{array}$ & $\begin{array}{l}\text { Pyrethrins, fenvalerate, } \\
\text { permethrin, cyhalothrin, } \\
\text { baythroid,beta-cypermethrin, } \\
\text { deltamethrin, cypermethrin }\end{array}$ & $\begin{array}{l}\text { Aggregation- } \\
\text { based }\end{array}$ & $(287)$ \\
\hline \multirow[t]{2}{*}{ Clenbuterol (drug) } & Melamine & $\begin{array}{c}\text { LOD: } 2.8 \times \\
10^{-11} \mathrm{M}, \\
\text { linear range: } \\
\text { of } 2.8 \times 10^{-10} \\
\text { to } 2.8 \times 10^{-7} \\
\mathrm{M} \text { and } 2.8 \times \\
10^{-7} \text { to } 1.4 \times \\
10^{-6} \mathrm{M}\end{array}$ & $\begin{array}{c}\text { DL-epinephrine, Phe, Trp, Ala, } \\
\text { Uric acid, Gly, Glycerol, } \\
\text { Glucose, } \mathrm{Mg}^{2+}, \mathrm{Ca}^{2+}, \mathrm{Na}^{+}\end{array}$ & $\begin{array}{l}\text { Aggregation- } \\
\text { based }\end{array}$ & $(288)$ \\
\hline & Cys & LOD: 50 nM & $\begin{array}{c}\text { Ala, phe, glycerol, vitamin, thr } \\
\text {,urea, cys, glucose, gly, } \mathrm{Na}^{+} \\
\mathrm{K}^{+}, \mathrm{Ca}^{2+}\end{array}$ & $\begin{array}{l}\text { Aggregation- } \\
\text { based }\end{array}$ & (289) \\
\hline
\end{tabular}


Table 4. Summary of colorimetric Au/Ag NPs system for small molecules sensing.

\begin{tabular}{|c|c|c|c|c|c|}
\hline $\begin{array}{c}\text { Methamphetamine } \\
\text { and cocaine } \\
\text { (drug) }\end{array}$ & Aptamers & $\begin{array}{l}\text { LOD: } 0.1 \mathrm{nM} \\
\text { (for meth); } 0.5 \\
\mathrm{nM} \text { (for coc), } \\
\text { linear range: } \\
\text { of 0.5-200 nM } \\
\text { (for meth); } 1- \\
150 \mathrm{nM} \text { (for } \\
\text { coc) }\end{array}$ & $\begin{array}{c}\text { Ketamine (KET), } \\
\text { norketamine(NK), morphine } \\
\text { (MOR), cocaine (COC), } \\
\text { cathinone (CAT), } \\
\text { methcathinone (MCAT), 3- } \\
\text { trifluoromethyphenylpiperazine } \\
\text { (BZP), and 4,4'- two amino two } \\
\text { phenyl methane (MDA) }\end{array}$ & $\begin{array}{c}\text { Aggregation- } \\
\text { based }\end{array}$ & $(276,277)$ \\
\hline
\end{tabular}




\subsubsection{Colorimetric biosensors}

Alongside chemical sensors and by following the same principle, plasmonic colorimetric biosensors have been developed for a wide range of molecules such as vitamins, glucose, aniline, amino acids, peptides, proteins or DNA (see Table 5).

A glucose sensor can be fabricated based on the $\mathrm{Ag}$ etching from $\mathrm{Au} @ \mathrm{Ag}$ core@shell NPs by $\mathrm{H}_{2} \mathrm{O}_{2}$. (290) This well-known strategy is based on the production of $\mathrm{H}_{2} \mathrm{O}_{2}$ from the glucose oxidation (in the presence of glucose oxidase and dioxygen) which is proportional to the glucose concentration.

On the other hand, AgNPs stabilized with 4.4-bipyridine (4-DPD) were used by Li and co-workers to detect tryptophan in a micromolar range. (291) Tryptophan can interact with the pyridine ring of 4-DPD via $\pi-\pi$ interactions, and meanwhile carboxyl acid of tryptophan can also form hydrogen bonds with pyridine, which results in 4-DPD-functionalized AgNPs aggregation and the colour change from yellow to red. Another example of amino acid sensing was reported by Hong Qun Luo and coworkers where they developed a colorimetric growth sensor of arginine (Figure 20).(182) In this work, carbon quantum dots (CQDs) are employed as reducing and stabilizing agent of AuNPs. In the presence of arginine, the complexation 
between Au salt and CQDs cannot be formed and hence the final growth of the AuNPs is affected.

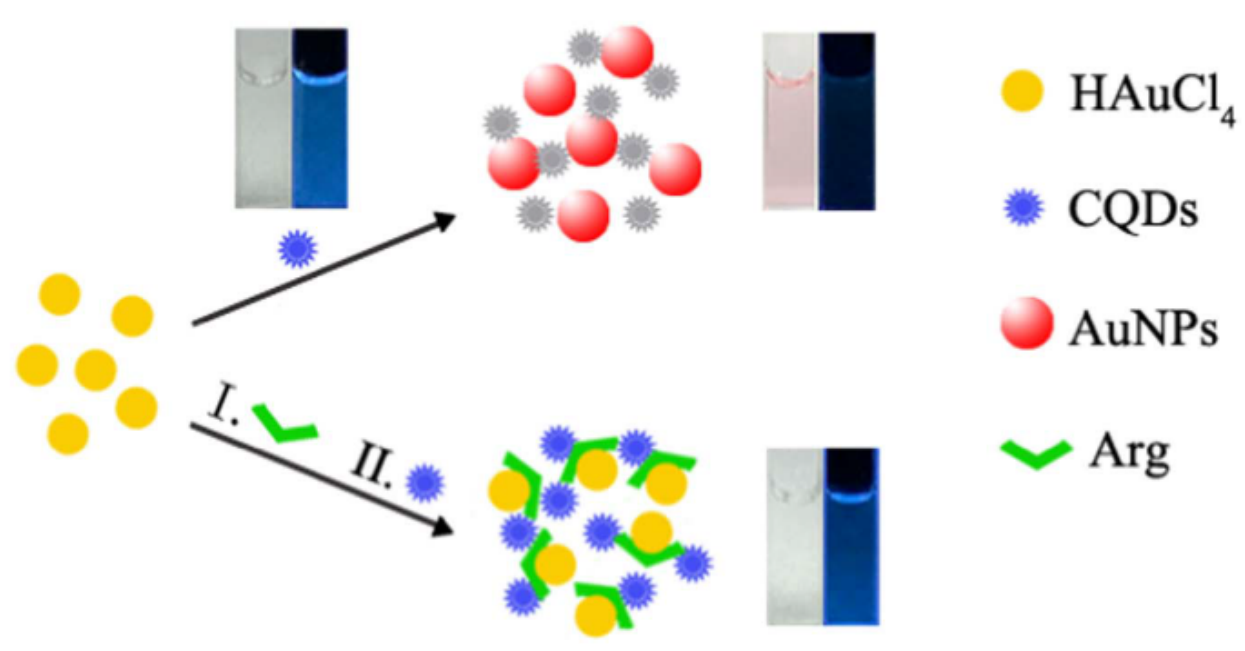

Figure 20. Schematic illustration for the detection of $\mathrm{Arg}$ by $\mathrm{CQDs}$ and $\mathrm{HAuCl}_{4}$ with both colorimetric and fluorometric readout. Adapted from ref (182) with permission of Elsevier.

DNA colorimetric biosensors has been also accomplished by using AuNPs functionalized with DNA,(292) dextrin, (293) or aptamers.(294) 


\begin{tabular}{|c|c|c|c|c|c|}
\hline Biomolecule & $\begin{array}{l}\text { Receptor } \\
\text { molecules }\end{array}$ & Sensitivity & Interferences & $\begin{array}{c}\text { Type of } \\
\text { colorimetric } \\
\text { detection }\end{array}$ & $\begin{array}{c}\text { Referenc } \\
\text { e }\end{array}$ \\
\hline Vitamin B1 & $\mathrm{GSH}$ & $\begin{array}{l}\text { LOD: } 50 \\
\mathrm{nM} \text {, linear } \\
\text { range: of 4- } \\
12 \mu \mathrm{M}\end{array}$ & $\begin{array}{l}\text { Vitamin B2, B3, B5, B6, B7,B9 B12 and C, } \\
\text { Amino acids(Cys, Trp, Tyr), GSH, Glucose, } \\
\qquad \mathrm{Hg}^{2+}, \mathrm{Cd}^{2+}, \mathrm{Cu}^{2+}, \mathrm{Zn}^{2+}\end{array}$ & $\begin{array}{l}\text { Aggregation } \\
\text {-based }\end{array}$ & (295) \\
\hline Glucose & $\begin{array}{l}\text { Poly( L - } \\
\text { histidine) and } \\
\text { GOx enzyme }\end{array}$ & $\begin{array}{c}\text { LOD: } 0.5 \times \\
10^{-6} \mathrm{M}, \\
\text { linear } \\
\text { range: of } ~ \\
0.5 \times 10^{-6} \\
\mathrm{M} \text { to } 0.02 \times \\
10^{-3} \mathrm{M}\end{array}$ & Fructose, Lactose, Sucrose & $\begin{array}{l}\text { Etching- } \\
\text { based }\end{array}$ & $(290)$ \\
\hline Aniline & $\begin{array}{l}\text { Diazonium salt } \\
\text { (DS) }\end{array}$ & $\begin{array}{l}\text { LOD: } 0.5 \\
\mu \mathrm{M}, \text { linear } \\
\text { range:5-60 } \\
\mu \mathrm{M}\end{array}$ & $\begin{array}{l}\text { Amino acids(Arg, Aspartic acid (Asp), } \\
\text { Glutamic acid (Glu), Gly, Histidine (His), Lys, } \\
\text { Ser, Thr, Trp), cations }\left(\mathrm{Na}^{+}, \mathrm{K}^{+}, \mathrm{Mg}^{2+},\right. \\
\left.\mathrm{Ca}^{2+}, \mathrm{Mn}^{2+}, \mathrm{Zn}^{2+}\right) \text {, anions }\left(\mathrm{CO}_{3}{ }^{2-}, \mathrm{NO}_{3}^{-}\right. \\
\left.\mathrm{HCO}_{3}{ }^{-}, \mathrm{HPO}_{4}{ }^{2-}, \mathrm{PO}_{4}{ }^{3-} \text { and } \mathrm{SO}_{4}{ }^{2-}\right)\end{array}$ & $\begin{array}{l}\text { Aggregation } \\
\text {-based }\end{array}$ & (296) \\
\hline
\end{tabular}




\begin{tabular}{|c|c|c|c|c|c|}
\hline \multirow{2}{*}{$\begin{array}{l}\text { Methionine } \\
\text { (Met) (amino } \\
\text { acid) }\end{array}$} & $\begin{array}{c}\text { Aptamer and } \\
\text { bio-dots }\end{array}$ & $\begin{array}{l}\text { LOD: } 3.7 \\
\text { nM , linear } \\
\text { range:5- } \\
350 \mathrm{nM}\end{array}$ & $\begin{array}{c}\text { Amino acids (Ala, Arg, Asn, Cys, Glutamine } \\
\text { (Gln), Gly, GSH, Hcy, His, Leu, Lys, Phe, } \\
\text { Proline (Pro), Val, Thr, Trp, Ser) }\end{array}$ & $\begin{array}{c}\text { Aggregation } \\
\text {-based }\end{array}$ & (297) \\
\hline & Melamine & $\begin{array}{l}\text { LOD: } 24.5 \\
\text { nM, linear } \\
\text { range: } 0-1 \\
\mu \mathrm{M}\end{array}$ & $\begin{array}{l}\text { Amino acids (Ala, Arg, Asn, Asp, Cys, Glu, } \\
\text { Gln, Gly, His, Isoleucine (Ile), Leu, Lys, Phe, } \\
\text { Pro, Val, Thr, Tyr, Trp, Ser), cation ( } \mathrm{Ca}^{2+} \\
\left.\mathrm{Fe}^{3+}, \mathrm{K}^{+}, \mathrm{Mg}^{2+}, \mathrm{Na}^{+} \text {and } \mathrm{NH}_{4}^{+}\right) \text {, and anions } \\
\qquad\left(\mathrm{CO}_{3}{ }^{2-}, \mathrm{HCO}_{3}{ }^{-} \text {, and } \mathrm{HPO}_{4}{ }^{2-}\right)\end{array}$ & $\begin{array}{c}\text { Aggregation } \\
\text {-based }\end{array}$ & $(298)$ \\
\hline \multirow{2}{*}{$\begin{array}{l}\text { Arg (amino } \\
\text { acid) }\end{array}$} & $\begin{array}{c}\text { Carbon } \\
\text { quantum dots }\end{array}$ & $\begin{array}{l}\text { LOD: } 37 \\
\mathrm{nM} \text {, linear } \\
\text { range: } 0.1- \\
\quad 5 \mu \mathrm{M}\end{array}$ & $\begin{array}{c}\text { Amino acids (Asn, Asp, Cys, Gln, His, Leu, } \\
\text { Lys, Met, Phe, Pro, Trp) }\end{array}$ & $\begin{array}{l}\text { Growth- } \\
\text { based }\end{array}$ & $(182)$ \\
\hline & Pillar[5]arene & $\begin{array}{c}\text { LOD: } 0.6 \\
\qquad \mu \mathrm{M}\end{array}$ & $\begin{array}{c}\text { Amino acids (Ala, Asn, Asp, Cys, Glu, Gln, } \\
\text { Gly, His, Ile, Leu, Met, Phe, Pro, Val, Thr, } \\
\text { Tyr, Trp, Ser) }\end{array}$ & $\begin{array}{c}\text { Aggregation } \\
\text {-based }\end{array}$ & (299) \\
\hline
\end{tabular}




\begin{tabular}{|c|c|c|c|c|c|}
\hline \multirow{2}{*}{$\begin{array}{l}\text { L-cys (amino } \\
\text { acid) }\end{array}$} & Citrate & $\begin{array}{l}\text { LOD: } 3.3 \\
\mathrm{nM} \text {, linear } \\
\text { range: } 10- \\
172 \mathrm{nM}\end{array}$ & $\begin{array}{l}\text { Amino acids (Ala, Arg, Asn, Asp, Glu, Gln, } \\
\text { Gly, His, Ile, Leu, Lys, Met, Phe, Pro, Val, } \\
\text { Thr, Tyr, Trp, Ser), }\end{array}$ & $\begin{array}{l}\text { Aggregation } \\
\text {-based }\end{array}$ & $(300)$ \\
\hline & CTAB & $\begin{array}{l}\text { LOD: } 0.9 \\
\text { nM, linear } \\
\text { range: } \\
0.005-25 \\
\mu \mathrm{M}\end{array}$ & $\begin{array}{l}\text { Amino acids (Arg, Gly, His, Lys, Phe, Pro, } \\
\text { Ser), GHS, AA, urea, UA, Glc, cations } \\
\left(\mathrm{K}^{+}, \mathrm{Na}^{+}, \mathrm{Cr}^{3+}, \mathrm{Mn}^{2+}, \mathrm{Co}^{2+}, \mathrm{Ni}^{2+}, \mathrm{Cu}^{2+}, \mathrm{Zn}^{2+}, \mathrm{Cd}^{2+}, \mathrm{P}\right. \\
\text { b), anions }\left(\mathrm{S}^{2-}, \mathrm{SO}_{4}^{2-}\right)\end{array}$ & $\begin{array}{c}\text { Etching- } \\
\text { based }\end{array}$ & (301) \\
\hline $\begin{array}{c}\text { Trp (amino } \\
\text { acid) }\end{array}$ & 4,4-bipyridine & $\begin{array}{l}\text { LOD: } 20 \\
\mu \mathrm{M} \text {, linear } \\
\text { range: } 75- \\
500 \mu \mathrm{M}\end{array}$ & $\begin{array}{l}\text { Amino acids (Cys, Leu, Phe, Pro, Val, Thr, } \\
\text { Ser), pyroglutamane }\end{array}$ & $\begin{array}{c}\text { Aggregation } \\
\text {-based }\end{array}$ & (291) \\
\hline $\begin{array}{c}\text { GSH } \\
\text { (peptide) }\end{array}$ & Arg & $\begin{array}{l}\text { LOD: } 10.9 \\
\text { nM, linear } \\
\text { range: } 25- \\
375 \mathrm{nM}\end{array}$ & $\begin{array}{c}\text { Amino acids (Ala, Arg, Asn, Asp, Cys, Glu, } \\
\text { Gln, Gly, His, Ile, Leu, Lys, Met, Phe, Pro, } \\
\text { Val, Thr, Tyr, Trp, Ser) }\end{array}$ & $\begin{array}{c}\text { Aggregation } \\
\text {-based }\end{array}$ & (302) \\
\hline
\end{tabular}




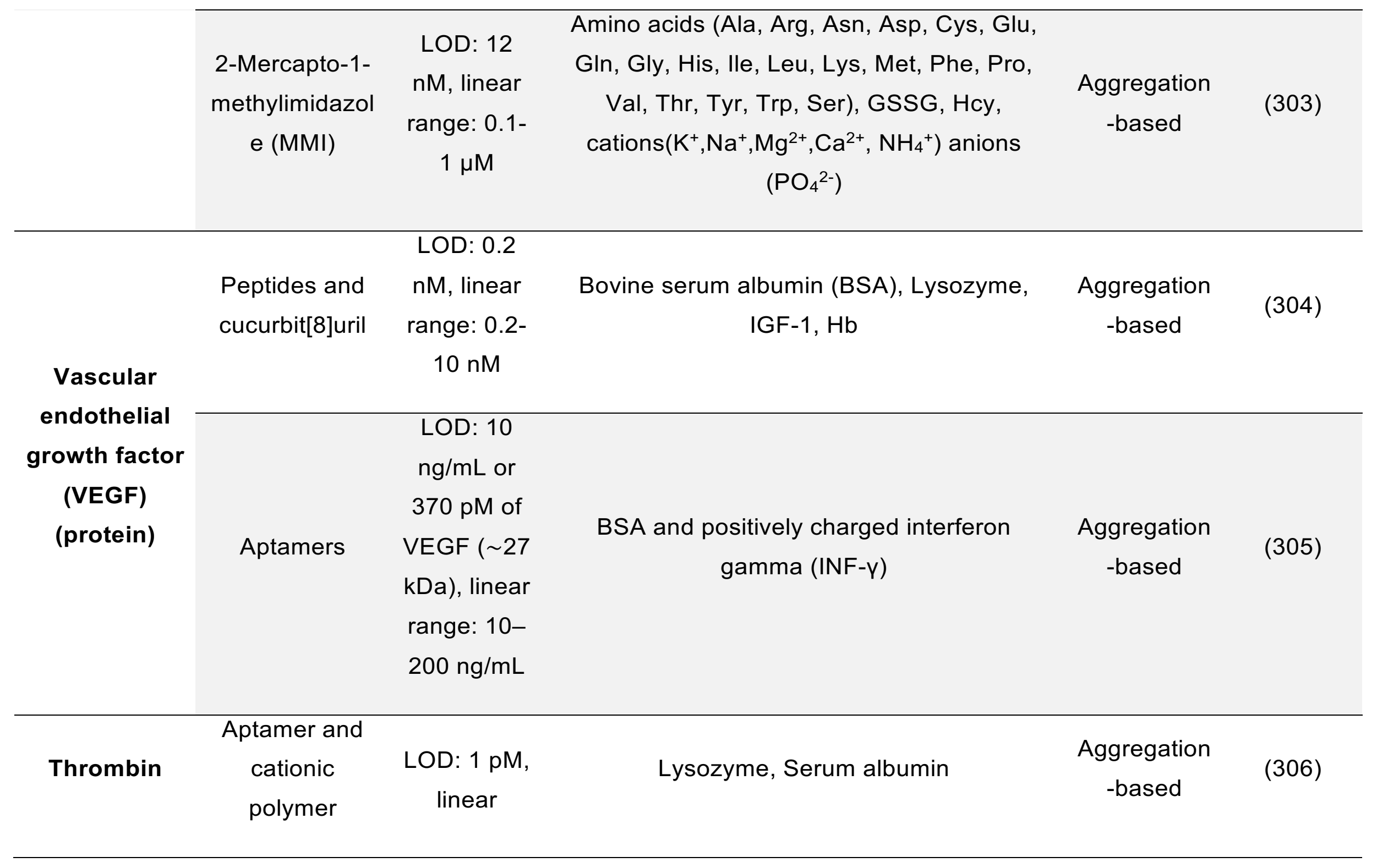




\begin{tabular}{|c|c|c|c|c|c|}
\hline & & $\begin{array}{c}\text { range: } 1 \\
\text { pM- } 10 \mathrm{nM}\end{array}$ & & & \\
\hline $\begin{array}{l}\text { Thrombin } \\
\text { and DNA }\end{array}$ & $\begin{array}{l}\text { Carbon } \\
\text { nanodots and } \\
\text { aptamers }\end{array}$ & $\begin{array}{l}\text { LOD: } 5 \mathrm{nM} \\
\text { for target } \\
\text { DNA and } \\
1.8 \mathrm{nM} \text { for } \\
\text { thrombin, } \\
\text { linear } \\
\text { range: } 0 \text { to } \\
128 \mathrm{nM} \text { for } \\
\text { target DNA } \\
\text { and 0-20 } \\
\text { nM for } \\
\text { thrombin }\end{array}$ & $\begin{array}{l}\text { Lysozyme, IgG, Human serum albumin } \\
\qquad \text { (HAS) }\end{array}$ & $\begin{array}{l}\text { Growth- } \\
\text { based }\end{array}$ & (307) \\
\hline $\begin{array}{l}\text { Adenosine } \\
\text { triphosphate } \\
\text { (ATP) } \\
\text { (nucleoside) }\end{array}$ & Aptamers & $\begin{array}{l}\text { LOD: } 50 \\
\text { nM, linear } \\
\text { range: } 50- \\
1000 \text { nM }\end{array}$ & $\begin{array}{l}\text { Nucleoside triphosphates (NTPs) guanosine } \\
\text { triphosphate (GTP), uridine triphosphate } \\
\text { (UTP), and cytidine triphosphate (CTP) }\end{array}$ & $\begin{array}{c}\text { Aggregation } \\
\text {-based }\end{array}$ & (308) \\
\hline
\end{tabular}




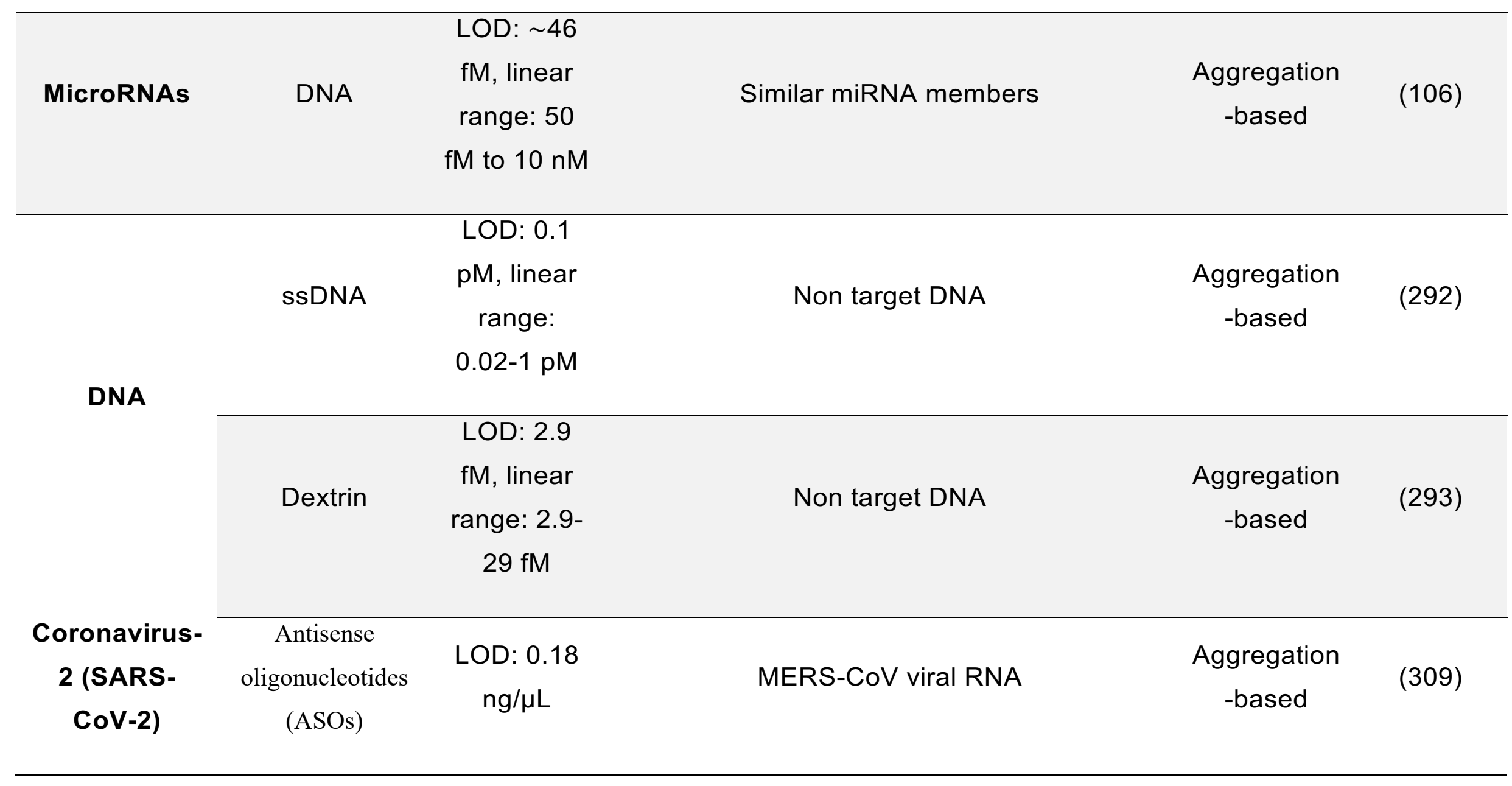




\subsubsection{Colorimetric sensor arrays}

During the last decade the approach of electronic tongue has also been applied to colorimetric sensors arrays. (310-315) Generally speaking, optical sensor arrays are based on either colorimetric and/or fluorescence assays, where the presence of target analytes triggers different intermolecular interactions with the receptors which are converted into a change of absorbance or luminescence signals by the transducer elements. Contrary to the "lock-andkey" sensing mode, each receptor does not necessarily have to respond specifically to a particular analyte but the group of responses provided by different sensing elements can generate a characteristic pattern that corresponds to each specific analyte. The two great advantages of colorimetric arrays are that no specific ad-hoc receptor of the analyte of interest is needed and also these kinds of array have the ability to discriminate between similar analytes within complex mixtures.

Three fundamental elements are needed for the design of an optical sensor array: i) a transducer element, which in the present review are metal nanoparticles; ii) a receptor molecule that can interact with the analyte/s of interest by any of the previously described colorimetric methodologies, and iii) a suitable statistical methods for pattern recognition and data analysis.

Although most of the examples have been focusing on metal ion detection, $(311,312,314)$ this methodology has been also applied for the detection of proteins,(310, 316) cells,(317) biomolecules,(318) bacteria,(319) pesticides(320) or opioids.(321)

For example, Denizli and co-workers presented a colorimetric sensor array for detection and discrimination toxic heavy metal ions $\left(\mathrm{Hg}^{2+}, \mathrm{Cd}^{2+}, \mathrm{Fe}^{3+}\right.$, $\mathrm{Pb}^{2+}, \mathrm{Al}^{3+}, \mathrm{Cu}^{2+}$, and $\mathrm{Cr}^{3+}$ ) in water (Figure 21).(312) Their methodology is based on the use of AuNPs stabilized with MUA and five amino acids (Lys, Cys, His, Tyr, and Arg). These amino acids possess functional groups that can form not only complexes with MUA, triggering the NPs assembly, but also with metal ions which can either enhance or diminish the particle aggregation. The combinatorial colorimetric response of all channels of the sensor array enabled naked-eye discrimination of all of the metal ions tested even in binary and ternary mixtures. 
A

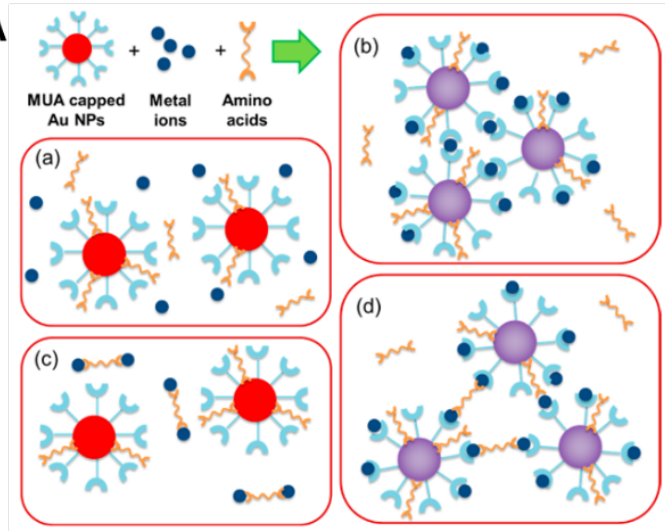

B

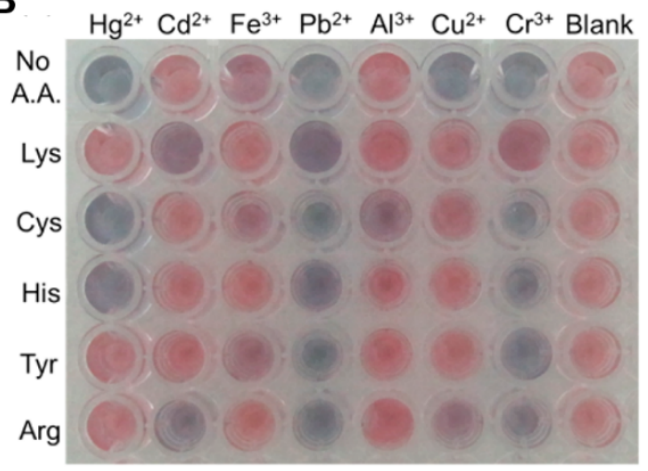

C
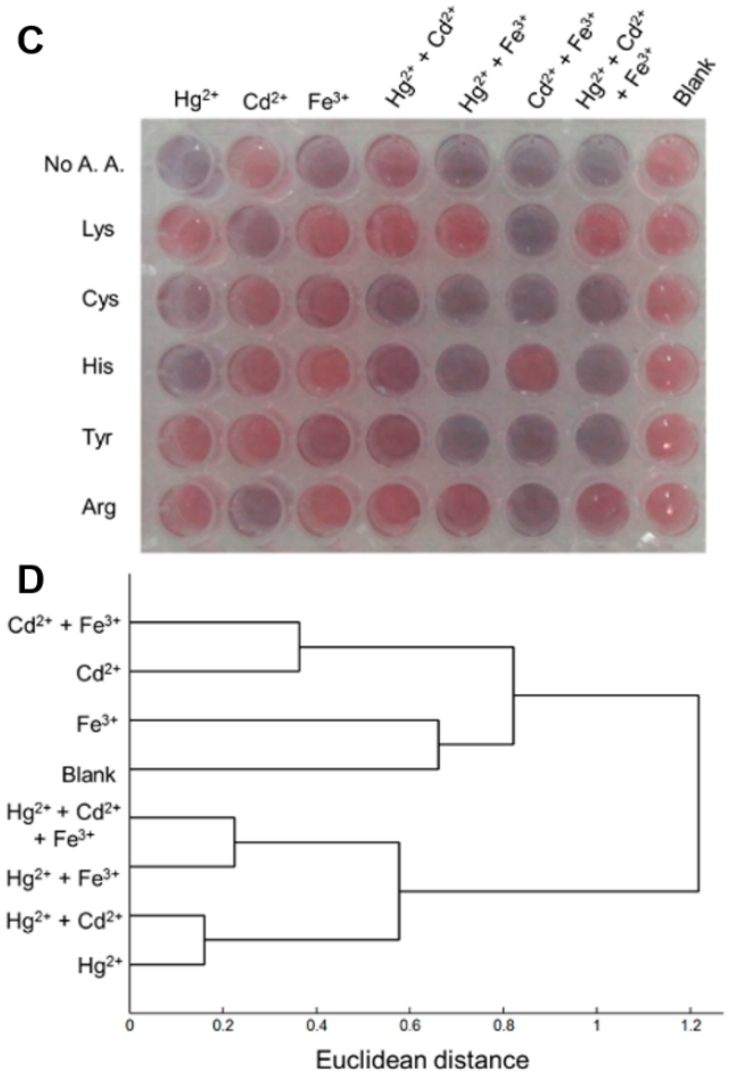

Figure 21. (a) Schematic Representation of Proposed Metal lons, Amino Acids, and AuNP Interactions: (a) No Interaction, (b) Metal Ions Induce the Aggregation of AuNPs, (c) Amino Acids Interact with Metal Ions and Prevent Aggregation of AuNPs; and (d) Metal Ions and Amino Acids Co-Contribute the Aggregation of AuNPs, (b) Representative photograph of the colorimetric sensor array response against $20 \mu \mathrm{M}$ of metal ions, (c-d) Colorimetric response of the colorimetric array against $\mathrm{Hg}^{2+}, \mathrm{Cd}^{2+}$, and $\mathrm{Fe}^{3+}$ ions $(20 \mathrm{M})$ and their binary and ternary mixtures. (c) Representative photograph and (d) hierarchical cluster analysis. Adapted with permission from reference (312). Copyright 2014 American Chemical Society.

The LSPR shift induced by local changes in the refractive index or by coupling between particles above discussed are the simplest and more immediate approaches to exploit metal nanoparticles as active materials or transducers in chemical sensing but the evanescent near field surrounding metal nanoparticles can be also exploited to strongly amplify the optical signals (including, fluorescence, IR absorption, and Raman) of molecules which are located in close proximity to the particle's surface. These techniques, called Surface-Enhanced Fluorescence (SEF),(322, 323) IR absorption (SEIRA)(324) 
and Raman spectroscopy (SERS),(325) have shown great potential in the field of sensing and, in particular, SERS can allow increased sensitivity up to singlemolecule detection $(326,327)$ but their working principles and their detailed description are far beyond the scope of this review.

\section{Conclusions and outlooks}

In this manuscript we have reviewed the use of noble metal nanoparticles (AuNPs and AgNPs) in chemical sensing by focussing on two read-out mechanisms, i.e. electrical and optical. The use of metal NPs which are versatile and highly sensitive scaffolds, together with the selectivity of capping agents/receptors can lead to the generation of new sensing systems. Besides, the strong capabilities of metal NPs to fabricate chemical nose/tongue sensors were also demonstrated in the multiplex detection of analytes in complex matrices.

Although chemiresistors dated back to 1985 , the use of metal NP as a sensing material is much more recent, especially for sensing in liquid media. Chemiresistors possess great advantages such as excellent sensitivity, cost effectiveness, simple sensing mechanism, and facile integration (e.g. miniaturization and/or portability). During the last decade many efforts have been devoted to the optimization of the sensitivity of these kinds of promising devices. Above all, the high sensitivity of the metal NPs based chemiresistors derives from the interplay between the supramolecular recognition between analytes and receptors, and the electron transport though the metal NPs networks.

On the other hand, the optical plasmonic sensors described in this review are extremely attractive due to its simplicity, cost-effectiveness, quickness, and unprecedent selectivity among the traditional detection methodologies. Moreover, colorimetric assays can be easily adaptable to smartphone devices, which are a potentially user-friendly, portable and powerful platform to detect, transduce and analyse on-line sensing information.(328) 
Despite these major progresses, there are still some critical points for both electrical and optical sensors which must be addressed urgently: i) the sensitivity is not enough for many analytes, such as molecular biomarkers which are usually found in picomolar levels in healthy individuals. ii) Multiplex detection of different analytes in the same sample is not usually possible. iii) Large scale industrial production has not been explored yet for colorimetric sensors. Most of the sensors have been used in model simplistic systems but not in real complex matrixes such as human serum.

Hence, in the near future research effort on the optical and electrical sensors based on metal NPs should address the following challenges: i) Improvement of the selectivity of the systems by exploring the sensing capabilities of new organic ligands (e.g. ad-hoc receptors) to be used as recognition elements. The use of organic ligands provides practical advantages due to their stability and their reduced cost in comparison with biomolecules such as DNA or antibodies, ii) Multiplex analyte detection. One may accomplish this by, for example, developing array-based systems composed of various recognition units, in analogy to chemical nose/tongue systems. A further complication may be associated to the need to develop versatile platforms for multiplex analyte detection which can operate with high performance both when detecting analytes similar in Nature (e.g. belonging to the same group) or rather different among them.

As long-term goals we can envision that the field will be focus on: i) Performance of complex matrices. This goal can be accomplished by the combination of the sensing protocols with statistical analysis. Statistical methods should be precisely designed in order to selectively sense the target analyte/s despite the presence of other interferences substances. Besides, the combination with ultra-sensitive detection methods, such as SERS, can be considered to be a future direction that can greatly enhance the discrimination power of sensor arrays and pave the way towards the development of a new generation of ultra-sensitive multi-analyte assays. ii) Ultimately, advances in this field could help in the development of stable, portable, low-cost and user-friendly substrates. Adopting microfluidic systems to current AuNP-based sensing 
methodologies may lead the way for cheap real-time monitoring systems for detection of analytes in complex matrices. The development of cell phone applications for both wireless signal readout and chemometric data analysis steps, miniaturization and the provision of easy-to-use point-of-care sensing kits are among further steps in the evolution of NP-based optical/electrical sensors.

Overall, chemical sensors based on both optical and electrical readout holds great potential for applications in which the devices operation can be optimized based on the chosen analyte and concentration thereof, environment of detection / portability and integration in a real technological platform.

\section{Conflicts of interest}

"There are no conflicts to declare".

\section{Acknowledgments}

This work was financially supported by European Commission through the Marie Sklodowska Curie ETN projects iSwitch (GA-642196), SYNCHRONICS (GA-643238) and BORGES (GA-813863), the ERC project SUPRA2DMAT (GA-833707), the AMI project funded by the ERA-NET EuroNanoMed III programme, the European Union and the Agence Nationale de la Recherche (ANR) GA-ANR-17-ENM3-0001-01, the Labex projects CSC (ANR-10LABX$0026 \mathrm{CSC}$ ) and NIE (ANR-11-LABX-0058 NIE) within the Investissement d'Avenir program ANR-10-IDEX-0002-02, the International Center for Frontier Research in Chemistry (icFRC) as well as BNF program and the Swiss National Foundation.

\section{Notes and references}

$\ddagger$ Footnotes relating to the main text should appear here. These might include comments relevant to but not central to the matter under discussion, limited experimental and spectral data, and crystallographic data.

\section{List of abbreviations}


Ab: Antibodies

ABTS: 2,2'-azino-bis(3-ethyl-benzothiazoline-6-sulfonic acid

AHMT: 4-amino-3-hydrazino-5-mercapto-1, 2, 4-triazole

Ala: Alanine

AMP: Ampicillin

Arg: Arginine

ASA: Acetyl salicylic acid

Asn: Asparagine

Asp: Aspartic acid

ATP: Adenosine triphosphate

BP-DTC: Dithiocarbamate-modified N-benzyl-4-(pyridin-4-ylmethyl)aniline

BSA: Bovine serum albumin

BZP: 3-trifluoromethyphenylpiperazine

CAT: Cathinone

CCR: Correct classification rate

CLP: Cardiolipin

COC: Cocaine

CQDs: Carbon quantum dots

CTAB: Cetyltrimethyl ammonium bromide

CTP: Cytidine triphosphate

Cys: Cysteine

DA: Dopamine

DES: Diethylstilbestrol

DMSA: meso-2,3-dimercaptosuccinic acid

DMSO: Dimethyl sulfoxide

DPPG: Dipalmitoyl phosphatidyl glycerol

DS: Diazonium salt

DTT: 1,4-dithiothreitol

DTTC: Diethyldithiocarbamate

E2: $17 \beta$-estradiol

EDC: (1-ethyl-3-(3-dimethylaminopropyl)carbodiimide)

EDTA: Ethylenediaminetetraacetic acid

EG: Ethylene glycol

ETC: Ethyl 1-(2-(3',4'-dihydroxyphenyl)-2-oxoethyl)-1H-1,2,3-triazole-4carboxylate

FIA: Flow injection analysis

FITC: Fluorescein isothiocyanate

GIn: Glutamine

Glu: Glutamic acid

Gly: Glycine

GSH: Glutathione

GTP: Guanosine triphosphate

HAS: Human serum albumin

His: Histidine

HT: Hexanethiol

IDA: Interdigitated array

INF-y: Interferon gamma

ILE: Isoleucine

Kana: Kanamycin

KET: Ketamine 
LbL: Layer-by-layer

Leu: Leucine

LDA: Linear discriminant analysis

LOD: Limit of detection

LS: Lauryl sulphate

LSP: Localized surface plasmon

LSPR: Localized Surface Plasmon Resonance

Lys: Lysine

MB: Methylene blue

MCAT: Methcathinone

MDA: 4,4'- two amino two phenyl methane

Met: Methionine

MIPs: Molecularly imprinted polymers

MMI: 2-Mercapto-1-methylimidazole

MNPs: Magnetic nanoparticles

MOR: Morphine

MSA: 2-Sulfanylethanesulfonate

MTT: 1-(2-mercaptoethyl)-1,2,3,4,5,6-hexanhydro-s-triazine-2,4,6-trione

MUA: 11-mercaptoundecanoic acid

mPEG-SH: Poly(ethylene glycol) methyl etherthiol

MW: Molecular weight

NED: Naphthylenediamine

NHS: N-hydroxysuccinimide

NIR: Near-infrared

NK: Norketamine

NPs: Nanoparticles

NTPs: Nucleoside triphosphates

OEG: Oligoethylene glycol

o,p'-DDT: Dichlorodiphenyltrichloroethane

PDDA: polydiallyldimethylammonium chloride

PEG: Poly(ethylene glycol)

PET: Polyethylene terephthalate

PFAs: Perfluoroalkyl substances

Phe: Phenylalanine

PPi: Pyrophosphate

PRG: Progesterone

PS 20: polysorbate20

PS 40: polysorbate40

Pro: Proline

PSP: Propagating surface plasmon

PVA: Polyvinyl alcohol

rGO: Reduced graphene oxide

$\mathrm{RH}$ : Humid air

SA: Sulphanilamide

SAM: Self-assembled monolayer

SEF: Surface-enhanced fluorescence

SEIRA: Surface-enhanced IR absorption

Ser: Serine

SERS: Surface-enhanced Raman scattering

SERRS: Surface-enhanced resonance Raman scattering 
SP: Surface Plasmons

ssDNA: single-stranded DNA

TBA: 2-thiobarbituric acid

THI: Thiamphenicol

Thr: Threonine

TMB: 3, 3',5,5'-tetramethlybenzidine

TOAB: Tetraoctyl ammonium bromide

Trp: Tryptophan

Tyr: Tyrosine

UTP: Uridine triphosphate

Val: Valine

VEGF: Vascular endothelial growth factor

Vis: Visible

VOCs: Volatile organic compounds

$\mu$ PAD: microfluidic paper-based analytical device

4-ABT: 4-aminobenzenthiol

4-CBD: 4-cyanobenzene diazonium tetrafluoroborate

4-DPD: 4.4-bipyridine

4-MB: 4-mercaptobutanol

7-ACA: 7-aminocephalosporanic acid

\section{References}

1. Ertem E, Diez-Castellnou M, Ong QK, \& Stellacci F (2018) Novel Sensing Strategies Based on Monolayer Protected Gold Nanoparticles for the Detection of Metal Ions and Small Molecules. The Chemical Record 18(7-8):819-828.

2. Saha K, Agasti SS, Kim C, Li X, \& Rotello VM (2012) Gold Nanoparticles in Chemical and Biological Sensing. Chemical Reviews 112(5):2739-2779.

3. Lee K-S \& El-Sayed MA (2006) Gold and Silver Nanoparticles in Sensing and Imaging: Sensitivity of Plasmon Response to Size, Shape, and Metal Composition. The Journal of Physical Chemistry B 110(39):19220-19225.

4. Faraday M (1857) X. The Bakerian Lecture. \&\#x2014; Experimental relations of gold (and other metals) to light. Philosophical Transactions of the Royal Society of London 147:145-181.

5. Wang Y \& Xia Y (2004) Bottom-Up and Top-Down Approaches to the Synthesis of Monodispersed Spherical Colloids of Low Melting-Point Metals. Nano Letters 4(10):20472050.

6. Biswas A, et al. (2012) Advances in top-down and bottom-up surface nanofabrication: Techniques, applications \& future prospects. Advances in Colloid and Interface Science 170(1):2-27.

7. Zhu M, Baffou G, Meyerbröker N, \& Polleux J (2012) Micropatterning Thermoplasmonic Gold Nanoarrays To Manipulate Cell Adhesion. ACS Nano 6(8):7227-7233.

8. Han X, Wu C, \& Sun S (2012) Photochemical reactions of thiol-terminated self-assembled monolayers (SAMs) for micropatterning of gold nanoparticles and controlled surface functionality. Applied Surface Science 258(12):5153-5156.

9. Manova E, et al. (2004) Mechano-Synthesis, Characterization, and Magnetic Properties of Nanoparticles of Cobalt Ferrite, CoFe2O4. Chemistry of Materials 16(26):5689-5696.

10. de Oliveira PFM, Quiroz J, de Oliveira DC, \& Camargo PHC (2019) A mechano-colloidal approach for the controlled synthesis of metal nanoparticles. Chemical Communications 55(95):14267-14270.

11. Shih C-M, Shieh Y-T, \& Twu Y-K (2009) Preparation of gold nanopowders and nanoparticles using chitosan suspensions. Carbohydrate Polymers 78(2):309-315. 
12. Guo J \& Suslick KS (2012) Gold nanoparticles encapsulated in porous carbon. Chemical Communications 48(90):11094-11096.

13. Montes-García V, et al. (2014) Pillar[5]arene-Mediated Synthesis of Gold Nanoparticles: Size Control and Sensing Capabilities. Chemistry - A European Journal 20(27):8404-8409.

14. Bastús NG, Merkoçi F, Piella J, \& Puntes V (2014) Synthesis of Highly Monodisperse CitrateStabilized Silver Nanoparticles of up to $200 \mathrm{~nm}$ : Kinetic Control and Catalytic Properties. Chemistry of Materials 26(9):2836-2846.

15. Eastoe J, Hollamby MJ, \& Hudson L (2006) Recent advances in nanoparticle synthesis with reversed micelles. Advances in Colloid and Interface Science 128-130:5-15.

16. Yoon Y-J, Kang S-H, Do C, Moon SY, \& Kim T-H (2019) Water-Redispersible and Highly Stable Gold Nanoparticles Permanently Capped by Charge-Controllable Surfactants for Potential Medical Applications. ACS Applied Nano Materials 2(12):7924-7932.

17. Li X, et al. (2019) Gamma irradiation and microemulsion assisted synthesis of monodisperse flower-like platinum-gold nanoparticles/reduced graphene oxide nanocomposites for ultrasensitive detection of carcinoembryonic antigen. Sensors and Actuators B: Chemical 287:267-277.

18. Dolgaev SI, Simakin AV, Voronov VV, Shafeev GA, \& Bozon-Verduraz F (2002) Nanoparticles produced by laser ablation of solids in liquid environment. Applied Surface Science 186(1):546551.

19. Mostafa AM \& Mwafy EA (2020) Synthesis of ZnO and Au@ZnO core/shell nano-catalysts by pulsed laser ablation in different liquid media. Journal of Materials Research and Technology 9(3):3241-3248.

20. Lee SH, et al. (2020) Selective synthesis of Au and graphitic carbon-encapsulated Au (Au@GC) nanoparticles by pulsed laser ablation in solvents: Catalytic Au and acid-resistant Au@GC nanoparticles. Applied Surface Science 506:145006.

21. Choi S-W, Jung S-H, \& Kim SS (2011) Significant enhancement of the NO2 sensing capability in networked $\mathrm{SnO} 2$ nanowires by Au nanoparticles synthesized via $y$-ray radiolysis. Journal of Hazardous Materials 193:243-248.

22. Araruna FB, et al. (2020) Antibacterial application of natural and carboxymethylated cashew gum-based silver nanoparticles produced by microwave-assisted synthesis. Carbohydrate Polymers 241:115260.

23. Baghbanzadeh M, Carbone L, Cozzoli PD, \& Kappe CO (2011) Microwave-Assisted Synthesis of Colloidal Inorganic Nanocrystals. Angewandte Chemie International Edition 50(48):1131211359.

24. Noël J-M, et al. (2020) Effect of the driving force on nanoparticles growth and shape: an optoelectrochemical study. Nanoscale 12(5):3227-3235.

25. Hill CM \& Pan S (2013) A Dark-Field Scattering Spectroelectrochemical Technique for Tracking the Electrodeposition of Single Silver Nanoparticles. Journal of the American Chemical Society 135(46):17250-17253.

26. Azharuddin $M$, et al. (2019) A repertoire of biomedical applications of noble metal nanoparticles. Chemical Communications 55(49):6964-6996.

27. Wang W, et al. (2014) One-pot fabrication and thermoelectric properties of Ag nanoparticlespolyaniline hybrid nanocomposites. RSC Advances 4(51):26810-26816.

28. Turkevich J, Stevenson PC, \& Hillier J (1951) A study of the nucleation and growth processes in the synthesis of colloidal gold. Discussions of the Faraday Society 11(0):55-75.

29. Lee PC \& Meisel D (1982) Adsorption and surface-enhanced Raman of dyes on silver and gold sols. The Journal of Physical Chemistry 86(17):3391-3395.

30. Pillai ZS \& Kamat PV (2004) What Factors Control the Size and Shape of Silver Nanoparticles in the Citrate Ion Reduction Method? The Journal of Physical Chemistry B 108(3):945-951.

31. Frens $G$ (1973) Controlled Nucleation for the Regulation of the Particle Size in Monodisperse Gold Suspensions. Nature Physical Science 241(105):20-22. 
32. Hong L, et al. (2018) Hybridization conditions of oligonucleotide-capped gold nanoparticles for SPR sensing of microRNA. Biosensors and Bioelectronics 109:230-236.

33. Nebu J, et al. (2018) Fluorescence turn-on detection of fenitrothion using gold nanoparticle quenched fluorescein and its separation using superparamagnetic iron oxide nanoparticle. Sensors and Actuators B: Chemical 277:271-280.

34. Daniel M-C \& Astruc D (2004) Gold Nanoparticles: Assembly, Supramolecular Chemistry, Quantum-Size-Related Properties, and Applications toward Biology, Catalysis, and Nanotechnology. Chemical Reviews 104(1):293-346.

35. Li N, Zhao P, \& Astruc D (2014) Anisotropic Gold Nanoparticles: Synthesis, Properties, Applications, and Toxicity. Angewandte Chemie International Edition 53(7):1756-1789.

36. Giersig M \& Mulvaney P (1993) Preparation of ordered colloid monolayers by electrophoretic deposition. Langmuir 9(12):3408-3413.

37. Brust M, Walker M, Bethell D, Schiffrin DJ, \& Whyman R (1994) Synthesis of thiol-derivatised gold nanoparticles in a two-phase Liquid-Liquid system. Journal of the Chemical Society, Chemical Communications (7):801-802.

38. Battocchio C, et al. (2012) Silver Nanoparticles Stabilized with Thiols: A Close Look at the Local Chemistry and Chemical Structure. The Journal of Physical Chemistry C 116(36):19571-19578.

39. Dichello GA, et al. (2017) Preparation of liposomes containing small gold nanoparticles using electrostatic interactions. European Journal of Pharmaceutical Sciences 105:55-63.

40. Lee JM, Youn YS, \& Lee ES (2017) Development of light-driven gas-forming liposomes for efficient tumor treatment. International Journal of Pharmaceutics 525(1):218-225.

41. Zheng N, Fan J, \& Stucky GD (2006) One-Step One-Phase Synthesis of Monodisperse NobleMetallic Nanoparticles and Their Colloidal Crystals. Journal of the American Chemical Society 128(20):6550-6551.

42. Seo D, Park JC, \& Song H (2006) Polyhedral Gold Nanocrystals with Oh Symmetry: From Octahedra to Cubes. Journal of the American Chemical Society 128(46):14863-14870.

43. Wiley B, Sun Y, \& Xia Y (2007) Synthesis of Silver Nanostructures with Controlled Shapes and Properties. Accounts of Chemical Research 40(10):1067-1076.

44. Lee Y-J, et al. (2013) Ultrasmooth, Highly Spherical Monocrystalline Gold Particles for Precision Plasmonics. ACS Nano 7(12):11064-11070.

45. Brown KR \& Natan MJ (1998) Hydroxylamine Seeding of Colloidal Au Nanoparticles in Solution and on Surfaces. Langmuir 14(4):726-728.

46. Brown KR, Lyon LA, Fox AP, Reiss BD, \& Natan MJ (2000) Hydroxylamine Seeding of Colloidal $\mathrm{Au}$ Nanoparticles. 3. Controlled Formation of Conductive Au Films. Chemistry of Materials 12(2):314-323.

47. Brown KR, Walter DG, \& Natan MJ (2000) Seeding of Colloidal Au Nanoparticle Solutions. 2. Improved Control of Particle Size and Shape. Chemistry of Materials 12(2):306-313.

48. Jana NR, Gearheart L, \& Murphy CJ (2001) Seeding Growth for Size Control of 5-40 nm Diameter Gold Nanoparticles. Langmuir 17(22):6782-6786.

49. Jana NR, Gearheart L, \& Murphy CJ (2001) Evidence for Seed-Mediated Nucleation in the Chemical Reduction of Gold Salts to Gold Nanoparticles. Chemistry of Materials 13(7):23132322.

50. Perrault SD \& Chan WCW (2009) Synthesis and Surface Modification of Highly Monodispersed, Spherical Gold Nanoparticles of 50-200 nm. Journal of the American Chemical Society 131(47):17042-17043.

51. Ziegler C \& Eychmüller A (2011) Seeded Growth Synthesis of Uniform Gold Nanoparticles with Diameters of 15-300 nm. The Journal of Physical Chemistry C 115(11):4502-4506.

52. Bastús NG, Comenge J, \& Puntes V (2011) Kinetically Controlled Seeded Growth Synthesis of Citrate-Stabilized Gold Nanoparticles of up to $200 \mathrm{~nm}$ : Size Focusing versus Ostwald Ripening. Langmuir 27(17):11098-11105. 
53. Liu X, Xu H, Xia H, \& Wang D (2012) Rapid Seeded Growth of Monodisperse, Quasi-Spherical, Citrate-Stabilized Gold Nanoparticles via H2O2 Reduction. Langmuir 28(38):13720-13726.

54. Pan A, et al. (2018) Topical Application of Keratinocyte Growth Factor Conjugated Gold Nanoparticles Accelerate Wound Healing. Nanomedicine: Nanotechnology, Biology and Medicine 14(5):1619-1628.

55. Lu L, et al. (2002) Seed-mediated growth of large, monodisperse core-shell gold-silver nanoparticles with Ag-like optical properties. Chemical Communications (2):144-145.

56. Steinigeweg D \& Schlücker S (2012) Monodispersity and size control in the synthesis of 20$100 \mathrm{~nm}$ quasi-spherical silver nanoparticles by citrate and ascorbic acid reduction in glycerolwater mixtures. Chemical Communications 48(69):8682-8684.

57. Niu J, Zhu T, \& Liu Z (2007) One-step seed-mediated growth of 30-150 nm quasispherical gold nanoparticles with 2-mercaptosuccinic acid as a new reducing agent. Nanotechnology 18(32):325607.

58. Wang Y, Wang M, Han L, Zhao Y, \& Fan A (2018) Enhancement effect of $p$-iodophenol on gold nanoparticle-catalyzed chemiluminescence and its applications in detection of thiols and guanidine. Talanta 182:523-528.

59. Daruich De Souza C, Ribeiro Nogueira B, \& Rostelato MECM (2019) Review of the methodologies used in the synthesis gold nanoparticles by chemical reduction. Journal of Alloys and Compounds 798:714-740.

60. Tarannum N, Divya, \& Gautam YK (2019) Facile green synthesis and applications of silver nanoparticles: a state-of-the-art review. RSC Advances 9(60):34926-34948.

61. Ganesh Kumar C, Poornachandra Y, \& Chandrasekhar C (2015) Green synthesis of bacterial mediated anti-proliferative gold nanoparticles: inducing mitotic arrest (G2/M phase) and apoptosis (intrinsic pathway). Nanoscale 7(44):18738-18750.

62. Mishra A, et al. (2011) Microbial synthesis of gold nanoparticles using the fungus Penicillium brevicompactum and their cytotoxic effects against mouse mayo blast cancer $\mathrm{C} 2 \mathrm{C} 12$ cells. Applied Microbiology and Biotechnology 92(3):617-630.

63. Shen W, et al. (2017) Catalytic reduction of 4-nitrophenol using gold nanoparticles biosynthesized by cell-free extracts of Aspergillus sp. WL-Au. Journal of Hazardous Materials 321:299-306.

64. Otari SV, Kumar M, Kim I-W, Lee JH, \& Lee J-K (2017) Rapid, thermostable antimicrobial peptide-mediated synthesis gold nanoparticles as highly efficient charge trapping medium for sol-gel-derived thin film. Materials Letters 188:375-378.

65. Pardha-Saradhi $P$, et al. (2014) Root system of live plants is a powerful resource for the green synthesis of Au-nanoparticles. RSC Advances 4(14):7361-7367.

66. Gan PP, Ng SH, Huang Y, \& Li SFY (2012) Green synthesis of gold nanoparticles using palm oil mill effluent (POME): A low-cost and eco-friendly viable approach. Bioresource Technology 113:132-135.

67. Mittal AK, Chisti Y, \& Banerjee UC (2013) Synthesis of metallic nanoparticles using plant extracts. Biotechnology Advances 31(2):346-356.

68. Park K, et al. (2017) Highly Concentrated Seed-Mediated Synthesis of Monodispersed Gold Nanorods. ACS Applied Materials \& Interfaces 9(31):26363-26371.

69. González-Ballesteros N, Prado-López S, Rodríguez-González JB, Lastra M, \& RodríguezArgüelles MC (2017) Green synthesis of gold nanoparticles using brown algae Cystoseira baccata: Its activity in colon cancer cells. Colloids and Surfaces B: Biointerfaces 153:190-198.

70. Chen $Y$, et al. (2017) Enhancing reducing ability of $\alpha$-zein by fibrillation for synthesis of $A u$ nanocrystals with continuous flow catalysis. Journal of Colloid and Interface Science 491:3743.

71. Ali TA, Mohamed GG, Azzam EMS, \& Abd-elaal AA (2014) Thiol surfactant assembled on gold nanoparticles ion exchanger for screen-printed electrode fabrication. Potentiometric 
determination of $\mathrm{Ce}(\mathrm{III})$ in environmental polluted samples. Sensors and Actuators B: Chemical 191:192-203.

72. Laurentius L, et al. (2011) Diazonium-Derived Aryl Films on Gold Nanoparticles: Evidence for a Carbon-Gold Covalent Bond. ACS Nano 5(5):4219-4227.

73. Bridonneau N, et al. (2018) N-Heterocyclic carbene-stabilized gold nanoparticles with tunable sizes. Dalton Transactions 47(19):6850-6859.

74. Hu P, Song Y, Chen L, \& Chen S (2015) Electrocatalytic activity of alkyne-functionalized AgAu alloy nanoparticles for oxygen reduction in alkaline media. Nanoscale 7(21):9627-9636.

75. Montes-García V, et al. (2018) Pillar[5]arene-stabilized Plasmonic Nanoparticles as Selective SERS Sensors. Israel Journal of Chemistry 58(11):1251-1260.

76. Kamra T, et al. (2016) Covalent immobilization of molecularly imprinted polymer nanoparticles on a gold surface using carbodiimide coupling for chemical sensing. Journal of Colloid and Interface Science 461:1-8.

77. Templeton AC, Wuelfing WP, \& Murray RW (2000) Monolayer-Protected Cluster Molecules. Accounts of Chemical Research 33(1):27-36.

78. Edwards W, Marro N, Turner G, \& Kay ER (2018) Continuum tuning of nanoparticle interfacial properties by dynamic covalent exchange. Chemical Science 9(1):125-133.

79. della Sala F \& Kay ER (2015) Reversible Control of Nanoparticle Functionalization and Physicochemical Properties by Dynamic Covalent Exchange. Angewandte Chemie International Edition 54(14):4187-4191.

80. Bodelón G, et al. (2015) Au@pNIPAM SERRS Tags for Multiplex Immunophenotyping Cellular Receptors and Imaging Tumor Cells. Small 11(33):4149-4157.

81. Mandal TK, Fleming MS, \& Walt DR (2002) Preparation of Polymer Coated Gold Nanoparticles by Surface-Confined Living Radical Polymerization at Ambient Temperature. Nano Letters 2(1):3-7.

82. Blanco-Covián L, et al. (2017) Au@Ag SERRS tags coupled to a lateral flow immunoassay for the sensitive detection of pneumolysin. Nanoscale 9(5):2051-2058.

83. Giljohann DA, et al. (2010) Gold Nanoparticles for Biology and Medicine. Angewandte Chemie International Edition 49(19):3280-3294.

84. Gao T, et al. (2019) Classification of Tea Aromas Using Multi-Nanoparticle Based Chemiresistor Arrays. Sensors 19(11):2547.

85. Xie ZZ, Raju MVR, Stewart AC, Nantz MH, \& Fu XA (2018) Imparting sensitivity and selectivity to a gold nanoparticle chemiresistor through thiol monolayer functionalization for sensing acetone. Rsc Advances 8(62):35618-35624.

86. Zhang PC, Dai Y, Viktorova J, Offenhausser A, \& Mayer D (2018) Electronic Responses to Humidity in Monolayer and Multilayer AuNP Stripes Fabricated by Convective Self-Assembly. Physica Status Solidi a-Applications and Materials Science 215(15).

87. AlQahtani H, Puzzovio D, Dragoneas A, Richardson T, \& Grell M (2012) A swelling-based chemiresistor for a biogenic odour. Talanta 99:50-54.

88. AlQahtani $\mathrm{H}$, et al. (2011) Highly sensitive alkane odour sensors based on functionalised gold nanoparticles. Sensors and Actuators B-Chemical 160(1):399-404.

89. Squillaci MA, Stoeckel M-A, \& Samorì P (2019) 3D hybrid networks of gold nanoparticles: mechanoresponsive electrical humidity sensors with on-demand performances. Nanoscale 11(41):19319-19326.

90. Zhao W, et al. (2016) Detection of mixed volatile organic compounds and lung cancer breaths using chemiresistor arrays with crosslinked nanoparticle thin films. Sensors and Actuators BChemical 232:292-299.

91. Madianos L, et al. (2018) Nanoparticle based gas-sensing array for pesticide detection. Journal of Environmental Chemical Engineering 6(5):6641-6646. 
92. Aoki PHB, Alessio P, Riul A, Saez JAD, \& Constantino CJL (2010) Coupling Surface-Enhanced Resonance Raman Scattering and Electronic Tongue as Characterization Tools to Investigate Biological Membrane Mimetic Systems. Analytical Chemistry 82(9):3537-3546.

93. Olichwer N, Leib EW, Halfar AH, Petrov A, \& Vossmeyer T (2012) Cross-Linked Gold Nanoparticles on Polyethylene: Resistive Responses to Tensile Strain and Vapors. Acs Applied Materials \& Interfaces 4(11):6151-6161.

94. Rao CNR, Kulkarni GU, Thomas PJ, \& Edwards PP (2000) Metal nanoparticles and their assemblies. Chemical Society Reviews 29(1):27-35.

95. Liao J, Bernard L, Langer M, Schönenberger C, \& Calame M (2006) Reversible Formation of Molecular Junctions in 2D Nanoparticle Arrays. Advanced Materials 18(18):2444-2447.

96. Liao J, et al. (2015) Ordered nanoparticle arrays interconnected by molecular linkers: electronic and optoelectronic properties. Chemical Society Reviews 44(4):999-1014.

97. Zabet-Khosousi A \& Dhirani A-A (2008) Charge Transport in Nanoparticle Assemblies. Chemical Reviews 108(10):4072-4124.

98. Snow AW \& Wohltjen H (1998) Size-Induced Metal to Semiconductor Transition in a Stabilized Gold Cluster Ensemble. Chemistry of Materials 10(4):947-949.

99. Terrill RH, et al. (1995) Monolayers in Three Dimensions: NMR, SAXS, Thermal, and Electron Hopping Studies of Alkanethiol Stabilized Gold Clusters. Journal of the American Chemical Society 117(50):12537-12548.

100. Duan C, et al. (2013) Controllability of the Coulomb charging energy in close-packed nanoparticle arrays. Nanoscale 5(21):10258-10266.

101. Middleton AA \& Wingreen NS (1993) Collective transport in arrays of small metallic dots. Physical Review Letters 71(19):3198-3201.

102. Wohltjen H \& Snow AW (1998) Colloidal Metal-Insulator-Metal Ensemble Chemiresistor Sensor. Analytical Chemistry 70(14):2856-2859.

103. Ibañez FJ \& Zamborini FP (2012) Chemiresistive Sensing with Chemically Modified Metal and Alloy Nanoparticles. Small 8(2):174-202.

104. Konvalina G \& Haick H (2012) Effect of Humidity on Nanoparticle-Based Chemiresistors: A Comparison between Synthetic and Real-World Samples. ACS Applied Materials \& Interfaces 4(1):317-325.

105. Tisch U \& Haick H (2010) Arrays of chemisensitive monolayer-capped metallic nanoparticles for diagnostic breath testing. Reviews in Chemical Engineering 26(5-6):171-179.

106. Olichwer N, Meyer A, Yesilmen M, \& Vossmeyer T (2016) Gold nanoparticle superlattices: correlating chemiresistive responses with analyte sorption and swelling. Journal of Materials Chemistry C 4(35):8214-8225.

107. Ghane T, et al. (2015) Interplay between Mechanical and Electronic Degrees of Freedom in $\pi$ Stacked Molecular Junctions: From Single Molecules to Mesoscopic Nanoparticle Networks. The Journal of Physical Chemistry C 119(11):6344-6355.

108. Garcia-Berrios E, et al. (2010) Response versus Chain Length of Alkanethiol-Capped Au Nanoparticle Chemiresistive Chemical Vapor Sensors. Journal of Physical Chemistry $C$ 114(50):21914-21920.

109. Tang J, et al. (2012) PHEMA functionalization of gold nanoparticles for vapor sensing: Chemiresistance, chemi-capacitance and chemi-impedance. Sensors and Actuators B-Chemical 170:129-136.

110. Segev-Bar M, Shuster G, \& Haick H (2012) Effect of Perforation on the Sensing Properties of Monolayer-Capped Metallic Nanoparticle Films. Journal of Physical Chemistry $C$ 116(29):15361-15368.

111. Bohrer Fl, Covington E, Kurdak C, \& Zellers ET (2011) Characterization of Dense Arrays of Chemiresistor Vapor Sensors with Submicrometer Features and Patterned Nanoparticle Interface Layers. Analytical Chemistry 83(10):3687-3695. 
112. Fu K, Chen ST, Zhao J, \& Willis BG (2016) Dielectrophoretic Assembly of Gold Nanoparticles in Nanoscale Junctions for Rapid, Miniature Chemiresistor Vapor Sensors. Acs Sensors 1(4):444450.

113. Wang $L Y$, et al. (2010) Flexible chemiresistor sensors: thin film assemblies of nanoparticles on a polyethylene terephthalate substrate. Journal of Materials Chemistry 20(5):907-915.

114. Yin J, et al. (2011) Molecularly Mediated Thin Film Assembly of Nanoparticles on Flexible Devices: Electrical Conductivity versus Device Strains in Different Gas/Vapor Environment. Acs Nano 5(8):6516-6526.

115. Shan SY, et al. (2014) Flexibility characteristics of a polyethylene terephthalate chemiresistor coated with a nanoparticle thin film assembly. Journal of Materials Chemistry C 2(10):18931903.

116. Jian RS, Huang RX, \& Lu CJ (2012) A micro GC detector array based on chemiresistors employing various surface functionalized monolayer-protected gold nanoparticles. Talanta 88:160-167.

117. Wright LK \& Zellers ET (2013) A nanoparticle-coated chemiresistor array as a microscale gas chromatograph detector for explosive marker compounds: flow rate and temperature effects. Analyst 138(22):6860-6868.

118. Ancona MG, Snow AW, Perkins FK, Pate B, \& Park D (2013) Analyte kinetics in a nanoclusterbased chemiresistor: A case study. Sensors and Actuators B-Chemical 177:936-946.

119. Yang Y, Cornwell LB, Ibanez FJ, \& Zamborini FP (2016) Chemiresistor Arrays Prepared by Simple and Fast Vapor-Phase Thiol Place-Exchange Functionalization of Gold Monolayer-Protected Cluster Films. Chemelectrochem 3(8):1230-1236.

120. Fu K, Li S, Jiang X, Wang Y, \& Willis BG (2013) DNA Gold Nanoparticle Nanocomposite Films for Chemiresistive Vapor Sensing. Langmuir 29(46):14335-14343.

121. Yan S, et al. (2017) Decoration of Nanofibrous Paper Chemiresistors with Dendronized Nanoparticles toward Structurally Tunable Negative-Going Response Characteristics to Human Breathing and Sweating. Advanced Materials Interfaces 4(22):1700380.

122. Krasteva N, et al. (2002) Self-Assembled Gold Nanoparticle/Dendrimer Composite Films for Vapor Sensing Applications. Nano Letters 2(5):551-555.

123. Shahar T, Feldheim G, Marx S, \& Mandler D (2018) Core-shell nanoparticles for gas phase detection based on silver nanospheres coated with a thin molecularly imprinted polymer adsorbed on a chemiresistor. Nanoscale 10(37):17593-17602.

124. Tang J, et al. (2012) PHEMA functionalization of gold nanoparticles for vapor sensing: Chemiresistance, chemi-capacitance and chemi-impedance. Sensors and Actuators B: Chemical 170:129-136.

125. Yao W, Chen X, \& Zhang J (2010) A capacitive humidity sensor based on gold-PVA core-shell nanocomposites. Sensors and Actuators B: Chemical 145(1):327-333.

126. Lee H-C, Wang C-Y, \& Lin C-H (2014) High-performance humidity sensors utilizing dopamine biomolecule-coated gold nanoparticles. Sensors and Actuators B: Chemical 191:204-210.

127. Im J, et al. (2011) A hybrid chemiresistive sensor system for the detection of organic vapors. Sensors and Actuators B-Chemical 156(2):715-722.

128. Luo JH, et al. (2012) Nanoparticle-structured thin film sensor arrays for breath sensing. Sensors and Actuators B-Chemical 161(1):845-854.

129. Li CL, Chen YF, Liu MH, \& Lu CJ (2012) Utilizing diversified properties of monolayer protected gold nano-clusters to construct a hybrid sensor array for organic vapor detection. Sensors and Actuators B-Chemical 169:349-359.

130. Raguse B, Chow E, Barton CS, \& Wieczorek L (2007) Gold Nanoparticle Chemiresistor Sensors: Direct Sensing of Organics in Aqueous Electrolyte Solution. Analytical Chemistry 79(19):73337339. 
131. Raguse B, Barton CS, Müller K-H, Chow E, \& Wieczorek L (2009) Gold Nanoparticle Chemiresistor Sensors in Aqueous Solution: Comparison of Hydrophobic and Hydrophilic Nanoparticle Films. The Journal of Physical Chemistry C 113(34):15390-15397.

132. Chow E, Herrmann J, Barton CS, Raguse B, \& Wieczorek L (2009) Inkjet-printed gold nanoparticle chemiresistors: Influence of film morphology and ionic strength on the detection of organics dissolved in aqueous solution. Analytica Chimica Acta 632(1):135-142.

133. Chow E, et al. (2010) Characterization of the Sensor Response of Gold Nanoparticle Chemiresistors. The Journal of Physical Chemistry C 114(41):17529-17534.

134. Müller K-H, et al. (2011) Dynamic response of gold nanoparticle chemiresistors to organic analytes in aqueous solution. Physical Chemistry Chemical Physics 13(40):18208-18216.

135. Reissner PA, Tisserant J-N, Sánchez-Ferrer A, Mezzenga R, \& Stemmer A (2016) Solventmediated conductance increase of dodecanethiol-stabilized gold nanoparticle monolayers. Beilstein J Nanotechnol 7:2057-2064.

136. Chow $\mathrm{E}$, et al. (2019) Solvent-induced modulation of the chemical sensing performance of gold nanoparticle film chemiresistors. Sensors and Actuators B: Chemical 284:316-322.

137. Chow E, et al. (2014) Chemiresistors: Transistor-Like Modulation of Gold Nanoparticle Film Conductivity Using Hydrophobic Ions (Adv. Mater. Interfaces 5/2014). Advanced Materials Interfaces 1(5).

138. Kang N, et al. (2016) Nanoparticle-Nanofibrous Membranes as Scaffolds for Flexible Sweat Sensors. ACS Sensors 1(8):1060-1069.

139. Chow E, Gengenbach TR, Wieczorek L, \& Raguse B (2010) Detection of organics in aqueous solution using gold nanoparticles modified with mixed monolayers of 1-hexanethiol and 4mercaptophenol. Sensors and Actuators B: Chemical 143(2):704-711.

140. Cho ES, et al. (2012) Ultrasensitive detection of toxic cations through changes in the tunnelling current across films of striped nanoparticles. Nature Materials 11(11):978-985.

141. Chen CJ, Smeu M, \& Ratner MA (2014) Modeling ion sensing in molecular electronics. The Journal of Chemical Physics 140(5):054709.

142. Xiao X, Xu B, \& Tao N (2004) Changes in the Conductance of Single Peptide Molecules upon Metal-Ion Binding. Angewandte Chemie International Edition 43(45):6148-6152.

143. Bui PT \& Nishino T (2014) Electron transfer through coordination bond interaction between single molecules: conductance switching by a metal ion. Physical Chemistry Chemical Physics 16(12):5490-5494.

144. Foroushani A, et al. (2015) Tunnelling current recognition through core-satellite gold nanoparticles for ultrasensitive detection of copper ions. Chemical Communications 51(14):2921-2924.

145. Zhang Y, et al. (2016) Self-Assembled Core-Satellite Gold Nanoparticle Networks for Ultrasensitive Detection of Chiral Molecules by Recognition Tunneling Current. ACS Nano 10(5):5096-5103.

146. Lai LMH, et al. (2012) The Biochemiresistor: An Ultrasensitive Biosensor for Small Organic Molecules. Angewandte Chemie International Edition 51(26):6456-6459.

147. Tan F, et al. (2017) Highly sensitive detection of $\mathrm{Cr}(\mathrm{VI})$ by reduced graphene oxide chemiresistor and 1,4-dithiothreitol functionalized Au nanoparticles. Sensors and Actuators B: Chemical 247:265-272.

148. Liu Y-C, Hsu C-H, Lu B-J, Lin P-Y, \& Ho M-L (2018) Determination of nitrite ions in environment analysis with a paper-based microfluidic device. Dalton Transactions 47(41):14799-14807.

149. Yan Y, Warren SC, Fuller P, \& Grzybowski BA (2016) Chemoelectronic circuits based on metal nanoparticles. Nature Nanotechnology 11(7):603-608.

150. Guerrini L, Garcia-Rico E, Pazos-Perez N, \& Alvarez-Puebla RA (2017) Smelling, Seeing, Tasting-Old Senses for New Sensing. ACS Nano 11(6):5217-5222. 
151. Cooper JS, et al. (2010) Gold Nanoparticle Chemiresistor Sensor Array that Differentiates between Hydrocarbon Fuels Dissolved in Artificial Seawater. Analytical Chemistry 82(9):37883795.

152. Hubble $L$, et al. (2012) Gold nanoparticle chemiresistors operating in biological fluids. Lab on a Chip 12(17):3040-3048.

153. Webster MS, et al. (2015) Detection of bacterial metabolites for the discrimination of bacteria utilizing gold nanoparticle chemiresistor sensors. Sensors and Actuators B: Chemical 220:895902.

154. Hubble L, et al. (2015) High-Throughput Fabrication and Screening Improves Gold Nanoparticle Chemiresistor Sensor Performance. ACS Combinatorial Science 17(2):120-129.

155. Garcia-Hernandez C, Salvo Comino C, Martín-Pedrosa F, Rodriguez-Mendez ML, \& GarciaCabezon C (2018) Impedimetric electronic tongue based on nanocomposites for the analysis of red wines. Improving the variable selection method. Sensors and Actuators B: Chemical 277:365-372.

156. Passarelli N, Pérez LA, \& Coronado EA (2014) Plasmonic Interactions: From Molecular Plasmonics and Fano Resonances to Ferroplasmons. ACS Nano 8(10):9723-9728.

157. Barnes WL, Dereux A, \& Ebbesen TW (2003) Surface plasmon subwavelength optics. Nature 424(6950):824-830.

158. Myroshnychenko $V$, et al. (2008) Modelling the optical response of gold nanoparticles. Chemical Society Reviews 37(9):1792-1805.

159. Bohm D \& Pines D (1953) A Collective Description of Electron Interactions: III. Coulomb Interactions in a Degenerate Electron Gas. Physical Review 92(3):609-625.

160. Mie G (1908) Beiträge zur Optik trüber Medien, speziell kolloidaler Metallösungen. Annalen der Physik 330(3):377-445.

161. Langer J, Novikov SM, \& Liz-Marzán LM (2015) Sensing using plasmonic nanostructures and nanoparticles. Nanotechnology 26(32):322001.

162. Kravets VG, Kabashin AV, Barnes WL, \& Grigorenko AN (2018) Plasmonic Surface Lattice Resonances: A Review of Properties and Applications. Chemical Reviews 118(12):5912-5951.

163. Mayer KM \& Hafner JH (2011) Localized Surface Plasmon Resonance Sensors. Chemical Reviews 111(6):3828-3857.

164. Paterson S \& de la Rica R (2015) Solution-based nanosensors for in-field detection with the naked eye. Analyst 140(10):3308-3317.

165. Squillaci MA, et al. (2019) 2D hybrid networks of gold nanoparticles: mechanoresponsive optical humidity sensors. Nanoscale 11(41):19315-19318.

166. Convertino A, Cuscunà M, Martelli F, Manera MG, \& Rella R (2014) Silica Nanowires Decorated with Metal Nanoparticles for Refractive Index Sensors: Three-Dimensional Metal Arrays and Light Trapping at Plasmonic Resonances. The Journal of Physical Chemistry C 118(1):685-690.

167. Ode K, Honjo M, Takashima Y, Tsuruoka T, \& Akamatsu K (2016) Highly Sensitive Plasmonic Optical Sensors Based on Gold Core-Satellite Nanostructures Immobilized on Glass Substrates. ACS Applied Materials \& Interfaces 8(32):20522-20526.

168. Dong P, Lin Y, Deng J, \& Di J (2013) Ultrathin Gold-Shell Coated Silver Nanoparticles onto a Glass Platform for Improvement of Plasmonic Sensors. ACS Applied Materials \& Interfaces 5(7):2392-2399.

169. Yang H-W, et al. (2016) Fabrication of a Nanogold-Dot Array for Rapid and Sensitive Detection of Vascular Endothelial Growth Factor in Human Serum. ACS Applied Materials \& Interfaces $8(45): 30845-30852$.

170. Zhang J, et al. (2013) A protein A modified Au-graphene oxide composite as an enhanced sensing platform for SPR-based immunoassay. Analyst 138(23):7175-7181.

171. Chen J, et al. (2015) Optimization and Application of Reflective LSPR Optical Fiber Biosensors Based on Silver Nanoparticles. Sensors 15(6):12205-12217. 
172. Frasconi M, Tortolini C, Botrè F, \& Mazzei F (2010) Multifunctional Au Nanoparticle Dendrimer-Based Surface Plasmon Resonance Biosensor and Its Application for Improved Insulin Detection. Analytical Chemistry 82(17):7335-7342.

173. SadAbadi H, Badilescu S, Packirisamy M, \& Wüthrich R (2013) Integration of gold nanoparticles in PDMS microfluidics for lab-on-a-chip plasmonic biosensing of growth hormones. Biosensors and Bioelectronics 44:77-84.

174. Huang Y, et al. (2017) A fiber-optic sensor for neurotransmitters with ultralow concentration: near-infrared plasmonic electromagnetic field enhancement using raspberry-like meso-SiO2 nanospheres. Nanoscale 9(39):14929-14936.

175. Cennamo N, et al. (2015) Sensitive detection of 2,4,6-trinitrotoluene by tridimensional monitoring of molecularly imprinted polymer with optical fiber and five-branched gold nanostars. Sensors and Actuators B: Chemical 208:291-298.

176. Chang C-C, et al. (2019) Gold Nanoparticle-Based Colorimetric Strategies for Chemical and Biological Sensing Applications. Nanomaterials 9(6):861.

177. Chen X-Y, Ha W, \& Shi Y-P (2019) Sensitive colorimetric detection of melamine in processed raw milk using asymmetrically PEGylated gold nanoparticles. Talanta 194:475-484.

178. Saa L, Coronado-Puchau M, Pavlov V, \& Liz-Marzán LM (2014) Enzymatic etching of gold nanorods by horseradish peroxidase and application to blood glucose detection. Nanoscale 6(13):7405-7409.

179. Da Q, Gu Y, Peng X, Zhang L, \& Du S (2018) Colorimetric and visual detection of mercury(II) based on the suppression of the interaction of dithiothreitol with agar-stabilized silver-coated gold nanoparticles. Microchimica Acta 185(7):357.

180. Chen C, Zhao D, Lu L, Yang F, \& Yang X (2015) A simple and rapid colorimetric sensor for sulfide anion detection based on redox reaction of ABTS with Au (III). Sensors and Actuators B: Chemical 220:1247-1253.

181. Farrokhnia M, Karimi S, \& Askarian S (2019) Strong Hydrogen Bonding of Gallic Acid during Synthesis of an Efficient AgNPs Colorimetric Sensor for Melamine Detection via Dis-synthesis Strategy. ACS Sustainable Chemistry \& Engineering 7(7):6672-6684.

182. Liu T, et al. (2017) A colorimetric and fluorometric dual-signal sensor for arginine detection by inhibiting the growth of gold nanoparticles/carbon quantum dots composite. Biosensors and Bioelectronics 87:772-778.

183. Rodríguez-Lorenzo L, de la Rica R, Álvarez-Puebla RA, Liz-Marzán LM, \& Stevens MM (2012) Plasmonic nanosensors with inverse sensitivity by means of enzyme-guided crystal growth. Nature Materials 11(7):604-607.

184. Sui $\mathrm{N}$, et al. (2017) Nano Au-Hg amalgam for $\mathrm{Hg} 2+$ and $\mathrm{H} 2 \mathrm{O} 2$ detection. Sensors and Actuators B: Chemical 252:1010-1015.

185. Zhao Y, Huang Y, Zhu H, Zhu Q, \& Xia Y (2016) Three-in-One: Sensing, Self-Assembly, and Cascade Catalysis of Cyclodextrin Modified Gold Nanoparticles. Journal of the American Chemical Society 138(51):16645-16654.

186. He W, et al. (2013) Intrinsic catalytic activity of Au nanoparticles with respect to hydrogen peroxide decomposition and superoxide scavenging. Biomaterials 34(3):765-773.

187. Zhang H \& Yang K-L (2020) In situ formation and immobilization of gold nanoparticles on polydimethylsiloxane (PDMS) exhibiting catalase-mimetic activity. Chemical Communications 56(47):6416-6419.

188. Lin S-Y, Liu S-W, Lin C-M, \& Chen C-h (2002) Recognition of Potassium Ion in Water by 15Crown-5 Functionalized Gold Nanoparticles. Analytical Chemistry 74(2):330-335.

189. Kalluri JR, et al. (2009) Use of Gold Nanoparticles in a Simple Colorimetric and Ultrasensitive Dynamic Light Scattering Assay: Selective Detection of Arsenic in Groundwater. Angewandte Chemie International Edition 48(51):9668-9671. 
190. Yu M (2014) Colorimetric Detection of Trace Arsenic(<span class="sc-ex">iii</span>) in Aqueous Solution Using Arsenic Aptamer and Gold Nanoparticles. Australian Journal of Chemistry 67(5):813-818.

191. Chen L, Li J, \& Chen L (2014) Colorimetric Detection of Mercury Species Based on Functionalized Gold Nanoparticles. ACS Applied Materials \& Interfaces 6(18):15897-15904.

192. Liu X, et al. (2016) Single Gold Nanoparticle-Based Colorimetric Detection of Picomolar Mercury lon with Dark-Field Microscopy. Analytical Chemistry 88(4):2119-2124.

193. Bhattacharjee Y, Chatterjee D, \& Chakraborty A (2018) Mercaptobenzoheterocyclic compounds functionalized silver nanoparticle, an ultrasensitive colorimetric probe for $\mathrm{Hg}$ (II) detection in water with picomolar precision: A correlation between sensitivity and binding affinity. Sensors and Actuators B: Chemical 255:210-216.

194. Su D, et al. (2013) Colorimetric detection of Hg2+ using thioctic acid functionalized gold nanoparticles. RSC Advances 3(46):24618-24624.

195. Xie Y (2018) $\mathrm{K}+$ colorimetric detection in the nanomolar range based on $\mathrm{K}+$-aptamer quadruplex-NPs association. Sensors and Actuators B: Chemical 269:22-26.

196. Qiu J, et al. (2019) Rapid colorimetric detection of potassium ions based on crown ether modified Au NPs sensor. Sensors and Actuators B: Chemical 281:783-788.

197. Wu Y, et al. (2012) Cationic polymers and aptamers mediated aggregation of gold nanoparticles for the colorimetric detection of arsenic(iii) in aqueous solution. Chemical Communications 48(37):4459-4461.

198. Tan Z-Q, et al. (2014) Colorimetric Au Nanoparticle Probe for Speciation Test of Arsenite and Arsenate Inspired by Selective Interaction between Phosphonium Ionic Liquid and Arsenite. ACS Applied Materials \& Interfaces 6(22):19833-19839.

199. Shrivas K, Shankar R, \& Dewangan K (2015) Gold nanoparticles as a localized surface plasmon resonance based chemical sensor for on-site colorimetric detection of arsenic in water samples. Sensors and Actuators B: Chemical 220:1376-1383.

200. Gong L, et al. (2017) Colorimetric aggregation assay for arsenic(III) using gold nanoparticles. Microchimica Acta 184(4):1185-1190.

201. Wen S-H, Liang R-P, Zhang L, \& Qiu J-D (2018) Multimodal Assay of Arsenite Contamination in Environmental Samples with Improved Sensitivity through Stimuli-Response of Multiligands Modified Silver Nanoparticles. ACS Sustainable Chemistry \& Engineering 6(5):6223-6232.

202. Priyadarshni N, Nath P, Nagahanumaiah, \& Chanda N (2018) DMSA-Functionalized Gold Nanorod on Paper for Colorimetric Detection and Estimation of Arsenic (III and V) Contamination in Groundwater. ACS Sustainable Chemistry \& Engineering 6(5):6264-6272.

203. Nath P, Priyadarshni N, \& Chanda N (2018) Europium-Coordinated Gold Nanoparticles on Paper for the Colorimetric Detection of Arsenic(III, V) in Aqueous Solution. ACS Applied Nano Materials 1(1):73-81.

204. Tripathi RM, et al. (2014) Ultra-sensitive detection of mercury(II) ions in water sample using gold nanoparticles synthesized by Trichoderma harzianum and their mechanistic approach. Sensors and Actuators B: Chemical 204:637-646.

205. Gao Y, et al. (2014) A simple visual and highly selective colorimetric detection of $\mathrm{Hg} 2+$ based on gold nanoparticles modified by 8-hydroxyquinolines and oxalates. Chemical Communications 50(49):6447-6450.

206. Sener G, Uzun L, \& Denizli A (2014) Lysine-Promoted Colorimetric Response of Gold Nanoparticles: A Simple Assay for Ultrasensitive Mercury(II) Detection. Analytical Chemistry 86(1):514-520.

207. Chen G-H, et al. (2014) Detection of Mercury(II) lons Using Colorimetric Gold Nanoparticles on Paper-Based Analytical Devices. Analytical Chemistry 86(14):6843-6849.

208. Buduru P, Reddy BCSR, \& Naidu NVS (2017) Functionalization of silver nanoparticles with glutamine and histidine for simple and selective detection of $\mathrm{Hg} 2+$ ion in water samples. Sensors and Actuators B: Chemical 244:972-982. 
209. Han KN, Choi J-S, \& Kwon J (2017) Gold nanozyme-based paper chip for colorimetric detection of mercury ions. Scientific Reports 7(1):2806.

210. Tian K, Siegel G, \& Tiwari A (2017) A simple and selective colorimetric mercury (II) sensing system based on chitosan stabilized gold nanoparticles and 2,6-pyridinedicarboxylic acid. Materials Science and Engineering: C 71:195-199.

211. Li L, Zhang L, Lou T, \& Chen Z (2017) Iodide-responsive Cu@Au nanoparticle-based colorimetric assay for sensitive mercury (II) detection. Sensors and Actuators B: Chemical 252:663-670.

212. Liu $\mathrm{Y}$, et al. (2017) Highly selective, colorimetric detection of $\mathrm{Hg} 2+$ based on three color changes of AuNPs solution from red through sandy beige to celandine green. Sensors and Actuators B: Chemical 249:331-338.

213. Tolessa T, Tan Z-Q, Yin Y-G, \& Liu J-F (2018) Single-drop gold nanoparticles for headspace microextraction and colorimetric assay of mercury (II) in environmental waters. Talanta 176:77-84.

214. Sajed S, Arefi F, Kolahdouz M, \& Sadeghi MA (2019) Improving sensitivity of mercury detection using learning based smartphone colorimetry. Sensors and Actuators B: Chemical 298:126942.

215. Amanulla B, Perumal KN, \& Ramaraj SK (2019) Chitosan functionalized gold nanoparticles assembled on sulphur doped graphitic carbon nitride as a new platform for colorimetric detection of trace Hg2+. Sensors and Actuators B: Chemical 281:281-287.

216. Chai F, Wang C, Wang T, Li L, \& Su Z (2010) Colorimetric Detection of Pb2+ Using Glutathione Functionalized Gold Nanoparticles. ACS Applied Materials \& Interfaces 2(5):1466-1470.

217. Huang K-W, Yu C-J, \& Tseng W-L (2010) Sensitivity enhancement in the colorimetric detection of lead(II) ion using gallic acid-capped gold nanoparticles: Improving size distribution and minimizing interparticle repulsion. Biosensors and Bioelectronics 25(5):984-989.

218. Hung Y-L, Hsiung T-M, Chen Y-Y, \& Huang C-C (2010) A label-free colorimetric detection of lead ions by controlling the ligand shells of gold nanoparticles. Talanta 82(2):516-522.

219. Zhu D, Li X, Liu X, Wang J, \& Wang Z (2012) Designing bifunctionalized gold nanoparticle for colorimetric detection of $\mathrm{Pb} 2+$ under physiological condition. Biosensors and Bioelectronics 31(1):505-509.

220. Mehta VN, Solanki JN, \& Kailasa SK (2014) Selective visual detection of Pb(II) ion via gold nanoparticles coated with a dithiocarbamate-modified 4'-aminobenzo-18-crown-6. Microchimica Acta 181(15):1905-1915.

221. Panich S, et al. (2014) Label-Free Pb(II) Whispering Gallery Mode Sensing Using SelfAssembled Glutathione-Modified Gold Nanoparticles on an Optical Microcavity. Analytical Chemistry 86(13):6299-6306.

222. Huang $Y$, et al. (2014) Target-Responsive DNAzyme Cross-Linked Hydrogel for Visual Quantitative Detection of Lead. Analytical Chemistry 86(22):11434-11439.

223. Chen B, et al. (2014) Scanometric nanomolar lead (II) detection using DNA-functionalized gold nanoparticles and silver stain enhancement. Sensors and Actuators B: Chemical 200:310-316.

224. Ratnarathorn N, Chailapakul O, \& Dungchai W (2015) Highly sensitive colorimetric detection of lead using maleic acid functionalized gold nanoparticles. Talanta 132:613-618.

225. Yun W, et al. (2016) Enzyme-free and label-free ultra-sensitive colorimetric detection of Pb2+ using molecular beacon and DNAzyme based amplification strategy. Biosensors and Bioelectronics 80:187-193.

226. Yu Y, Hong Y, Gao P, \& Nazeeruddin MK (2016) Glutathione Modified Gold Nanoparticles for Sensitive Colorimetric Detection of Pb2+ Ions in Rainwater Polluted by Leaking Perovskite Solar Cells. Analytical Chemistry 88(24):12316-12322.

227. Priyadarshini E \& Pradhan N (2017) Metal-induced aggregation of valine capped gold nanoparticles: An efficient and rapid approach for colorimetric detection of $\mathrm{Pb} 2+$ ions. Scientific Reports 7(1):9278. 
228. Solra M, et al. (2020) Optical pico-biosensing of lead using plasmonic gold nanoparticles and a cationic peptide-based aptasensor. Chemical Communications 56(2):289-292.

229. Ma Y-r, Niu H-y, Zhang X-I, \& Cai Y-q (2011) Colorimetric detection of copper ions in tap water during the synthesis of silver/dopamine nanoparticles. Chemical Communications 47(47):12643-12645.

230. Lou T, et al. (2011) Colorimetric Detection of Trace Copper lons Based on Catalytic Leaching of Silver-Coated Gold Nanoparticles. ACS Applied Materials \& Interfaces 3(11):4215-4220.

231. Ratnarathorn N, Chailapakul O, Henry CS, \& Dungchai W (2012) Simple silver nanoparticle colorimetric sensing for copper by paper-based devices. Talanta 99:552-557.

232. Liu R, et al. (2013) Colorimetric sensing of copper(II) based on catalytic etching of gold nanoparticles. Talanta 112:37-42.

233. Weng Z, et al. (2013) Self-assembly of core-satellite gold nanoparticles for colorimetric detection of copper ions. Analytica Chimica Acta 803:128-134.

234. Basiri S, Mehdinia A, \& Jabbari A (2018) Green synthesis of reduced graphene oxide-Ag nanoparticles as a dual-responsive colorimetric platform for detection of dopamine and $\mathrm{Cu} 2+$. Sensors and Actuators B: Chemical 262:499-507.

235. Zhao L, Jin Y, Yan Z, Liu Y, \& Zhu H (2012) Novel, highly selective detection of $\mathrm{Cr}$ (III) in aqueous solution based on a gold nanoparticles colorimetric assay and its application for determining $\mathrm{Cr}(\mathrm{VI})$. Analytica Chimica Acta 731:75-81.

236. Chen W, et al. (2015) Detection of the nanomolar level of total $\operatorname{Cr}[($ iii) and (vi)] by functionalized gold nanoparticles and a smartphone with the assistance of theoretical calculation models. Nanoscale 7(5):2042-2049.

237. Dong C, et al. (2016) Selective colorimetric detection of $\mathrm{Cr}(\mathrm{iii})$ and $\mathrm{Cr}(\mathrm{vi})$ using gallic acid capped gold nanoparticles. Dalton Transactions 45(20):8347-8354.

238. Yu Y, Hong Y, Wang Y, Sun X, \& Liu B (2017) Mecaptosuccinic acid modified gold nanoparticles as colorimetric sensor for fast detection and simultaneous identification of $\mathrm{Cr} 3+$. Sensors and Actuators B: Chemical 239:865-873.

239. Kanagaraj R, Nam Y-S, Pai SJ, Han SS, \& Lee K-B (2017) Highly selective and sensitive detection of $\mathrm{Cr} 6+$ ions using size-specific label-free gold nanoparticles. Sensors and Actuators B: Chemical 251:683-691.

240. Wang A-J, et al. (2013) Sensitive and selective colorimetric detection of cadmium(II) using gold nanoparticles modified with 4-amino-3-hydrazino-5-mercapto-1,2,4-triazole. Microchimica Acta 180(11):1051-1057.

241. Guo Y, et al. (2014) Label-Free Colorimetric Detection of Cadmium lons in Rice Samples Using Gold Nanoparticles. Analytical Chemistry 86(17):8530-8534.

242. Sung Y-M \& Wu S-P (2014) Colorimetric detection of Cd(II) ions based on di-(1H-pyrrol-2yl)methanethione functionalized gold nanoparticles. Sensors and Actuators B: Chemical 201:86-91.

243. Mehta VN, Basu H, Singhal RK, \& Kailasa SK (2015) Simple and sensitive colorimetric sensing of $\mathrm{Cd} 2+$ ion using chitosan dithiocarbamate functionalized gold nanoparticles as a probe. Sensors and Actuators B: Chemical 220:850-858.

244. Zhang Y, et al. (2015) A bifunctional sensor based on Au-Fe3O4 nanoparticle for the detection of Cd2+. Sensors and Actuators B: Chemical 220:622-626.

245. Eom MS, et al. (2012) A bi-ligand co-functionalized gold nanoparticles-based calcium ion probe and its application to the detection of calcium ions in serum. Chemical Communications 48(45):5566-5568.

246. Nadav L, Tsion O-R, \& Offer Z (2020) Improving the properties of a gold nanoparticle barium sensor through mixed-ligand shells. Talanta 208:120370.

247. Maity D, Gupta R, Gunupuru R, Srivastava DN, \& Paul P (2014) Calix[4]arene functionalized gold nanoparticles: Application in colorimetric and electrochemical sensing of cobalt ion in organic and aqueous medium. Sensors and Actuators B: Chemical 191:757-764. 
248. Kim D-Y, Shinde S, \& Ghodake G (2017) Colorimetric detection of magnesium (II) ions using tryptophan functionalized gold nanoparticles. Scientific Reports 7(1):3966.

249. Safavi A, Ahmadi R, \& Mohammadpour Z (2017) Colorimetric sensing of silver ion based on anti aggregation of gold nanoparticles. Sensors and Actuators B: Chemical 242:609-615.

250. Li X, Wu Z, Zhou X, \& Hu J (2017) Colorimetric response of peptide modified gold nanoparticles: An original assay for ultrasensitive silver detection. Biosensors and Bioelectronics 92:496-501.

251. Du J, Du H, Ge H, Fan J, \& Peng X (2018) A plasmonic nano-sensor for the fast detection of Ag+ based on synergistic coordination-inspired gold nanoparticle. Sensors and Actuators B: Chemical 255:808-813.

252. Buduru P \& Reddy B.C SR (2016) Oxamic acid and p-aminobenzoic acid functionalized gold nanoparticles as a probe for colorimetric detection of Fe3+ ion. Sensors and Actuators B: Chemical 237:935-943.

253. Li J-j, et al. (2017) Colorimetric measurement of Fe3+ using a functional paper-based sensor based on catalytic oxidation of gold nanoparticles. Sensors and Actuators B: Chemical 242:1265-1271.

254. Memon SS, et al. (2018) Sensitive and selective aggregation based colorimetric sensing of Fe3+ via interaction with acetyl salicylic acid derived gold nanoparticles. Sensors and Actuators B: Chemical 259:1006-1012.

255. Lee S, Nam Y-S, Lee H-J, Lee Y, \& Lee K-B (2016) Highly selective colorimetric detection of Zn(II) ions using label-free silver nanoparticles. Sensors and Actuators B: Chemical 237:643-651.

256. Huang P, Li J, Liu X, \& WU F (2016) Colorimetric determination of aluminum(III) based on the aggregation of Schiff base-functionalized gold nanoparticles. Microchimica Acta 183(2):863869.

257. Rastogi L, Dash K, \& Ballal A (2017) Selective colorimetric/visual detection of Al3+ in ground water using ascorbic acid capped gold nanoparticles. Sensors and Actuators B: Chemical 248:124-132.

258. Sharma R, Dhillon A, \& Kumar D (2018) Mentha-Stabilized Silver Nanoparticles for HighPerformance Colorimetric Detection of $\mathrm{Al}(\mathrm{III})$ in Aqueous Systems. Scientific Reports $8(1): 5189$.

259. Luo $X$, et al. (2019) Ligands dissociation induced gold nanoparticles aggregation for colorimetric Al3+ detection. Analytica Chimica Acta 1087:76-85.

260. Kumar A, Bhatt M, Vyas G, Bhatt S, \& Paul P (2017) Sunlight Induced Preparation of Functionalized Gold Nanoparticles as Recyclable Colorimetric Dual Sensor for Aluminum and Fluoride in Water. ACS Applied Materials \& Interfaces 9(20):17359-17368.

261. Zheng W, Li H, Chen W, Ji J, \& Jiang X (2016) Recyclable Colorimetric Detection of Trivalent Cations in Aqueous Media Using Zwitterionic Gold Nanoparticles. Analytical Chemistry 88(7):4140-4146.

262. Xiong Y, et al. (2017) Janus PEGylated gold nanoparticles: a robust colorimetric probe for sensing nitrite ions in complex samples. Nanoscale 9(5):1811-1815.

263. Gu J-A, Lin Y-J, Chia Y-M, Lin H-Y, \& Huang S-T (2013) Colorimetric and bare-eye determination of fluoride using gold nanoparticle agglomeration probes. Microchimica Acta 180(9):801-806.

264. Sun J-F, Liu R, Zhang Z-M, \& Liu J-F (2014) Incorporation of the fluoride induced SiO bond cleavage and functionalized gold nanoparticle aggregation into one colorimetric probe for highly specific and sensitive detection of fluoride. Analytica Chimica Acta 820:139-145.

265. Boken J, Thatai S, Khurana P, Prasad S, \& Kumar D (2015) Highly selective visual monitoring of hazardous fluoride ion in aqueous media using thiobarbituric-capped gold nanoparticles. Talanta 132:278-284.

266. Cheng C, et al. (2016) A highly sensitive and selective cyanide detection using a gold nanoparticle-based dual fluorescence-colorimetric sensor with a wide concentration range. Sensors and Actuators B: Chemical 227:283-290. 
267. Li Y, et al. (2016) A convenient colorimetric method for sensitive and specific detection of cyanide using Ag@Au core-shell nanoparticles. Sensors and Actuators B: Chemical 228:366372.

268. Lu L, Zhang J, \& Yang X (2013) Simple and selective colorimetric detection of hypochlorite based on anti-aggregation of gold nanoparticles. Sensors and Actuators B: Chemical 184:189195.

269. Lee IL, Sung Y-M, Wu C-H, \& Wu S-P (2014) Colorimetric sensing of iodide based on triazoleacetamide functionalized gold nanoparticles. Microchimica Acta 181(5):573-579.

270. Du J, et al. (2012) Colorimetric Chemodosimeter Based on Diazonium-Gold-Nanoparticle Complexes for Sulfite Ion Detection in Solution. Small 8(22):3412-3416.

271. Zhao D, Chen C, Lu L, Yang F, \& Yang X (2015) A label-free colorimetric sensor for sulfate based on the inhibition of peroxidase-like activity of cysteamine-modified gold nanoparticles. Sensors and Actuators B: Chemical 215:437-444.

272. Qin L, et al. (2018) "Gold rush" in modern science: Fabrication strategies and typical advanced applications of gold nanoparticles in sensing. Coordination Chemistry Reviews 359:1-31.

273. Shen J, et al. (2016) Functionalized Au-Fe3O4 nanocomposites as a magnetic and colorimetric bimodal sensor for melamine. Sensors and Actuators B: Chemical 226:512-517.

274. Jigyasa \& Rajput JK (2018) Bio-polyphenols promoted green synthesis of silver nanoparticles for facile and ultra-sensitive colorimetric detection of melamine in milk. Biosensors and Bioelectronics 120:153-159.

275. Bala R, Kumar M, Bansal K, Sharma RK, \& Wangoo N (2016) Ultrasensitive aptamer biosensor for malathion detection based on cationic polymer and gold nanoparticles. Biosensors and Bioelectronics 85:445-449.

276. Mao K, et al. (2017) A novel colorimetric biosensor based on non-aggregated Au@Ag coreshell nanoparticles for methamphetamine and cocaine detection. Talanta 175:338-346.

277. Mao K, Ma J, Li X, \& Yang Z (2019) Rapid duplexed detection of illicit drugs in wastewater using gold nanoparticle conjugated aptamer sensors. Science of The Total Environment 688:771779.

278. Ni P, et al. (2014) Visual detection of melamine based on the peroxidase-like activity enhancement of bare gold nanoparticles. Biosensors and Bioelectronics 60:286-291.

279. Zhang D, et al. (2016) Colorimetric detection of bisphenol A based on unmodified aptamer and cationic polymer aggregated gold nanoparticles. Analytical Biochemistry 499:51-56.

280. Zhang L-p, Xing Y-p, Liu L-h, Zhou X-h, \& Shi H-c (2016) Fenton reaction-triggered colorimetric detection of phenols in water samples using unmodified gold nanoparticles. Sensors and Actuators B: Chemical 225:593-599.

281. Niu H, et al. (2014) Sensitive Colorimetric Visualization of Perfluorinated Compounds Using Poly(ethylene glycol) and Perfluorinated Thiols Modified Gold Nanoparticles. Analytical Chemistry 86(9):4170-4177.

282. Qin L, et al. (2017) A visual application of gold nanoparticles: Simple, reliable and sensitive detection of kanamycin based on hydrogen-bonding recognition. Sensors and Actuators B: Chemical 243:946-954.

283. Rohit JV \& Kailasa SK (2017) Simple and selective detection of pendimethalin herbicide in water and food samples based on the aggregation of ractopamine-dithiocarbamate functionalized gold nanoparticles. Sensors and Actuators B: Chemical 245:541-550.

284. Rohit JV, Singhal RK, \& Kailasa SK (2016) Dithiocarbamate-calix[4]arene functionalized gold nanoparticles as a selective and sensitive colorimetric probe for assay of metsulfuron-methyl herbicide via non-covalent interactions. Sensors and Actuators B: Chemical 237:1044-1055.

285. Wu S, et al. (2017) Gold nanoparticles dissolution based colorimetric method for highly sensitive detection of organophosphate pesticides. Sensors and Actuators B: Chemical 238:427-433. 
286. Rohit JV, Basu H, Singhal RK, \& Kailasa SK (2016) Development of p-nitroaniline dithiocarbamate capped gold nanoparticles-based microvolume UV-vis spectrometric method for facile and selective detection of quinalphos insecticide in environmental samples. Sensors and Actuators B: Chemical 237:826-835.

287. Imene B, et al. (2014) 4-Amino-3-mercaptobenzoic acid functionalized gold nanoparticles: Synthesis, selective recognition and colorimetric detection of cyhalothrin. Sensors and Actuators B: Chemical 199:161-167.

288. Zhang $X$, et al. (2012) Colorimetric sensing of clenbuterol using gold nanoparticles in the presence of melamine. Biosensors and Bioelectronics 34(1):112-117.

289. Kang J, Zhang Y, Li X, Miao L, \& Wu A (2016) A Rapid Colorimetric Sensor of Clenbuterol Based on Cysteamine-Modified Gold Nanoparticles. ACS Applied Materials \& Interfaces 8(1):1-5.

290. He H, Xu X, Wu H, \& Jin Y (2012) Enzymatic Plasmonic Engineering of Ag/Au Bimetallic Nanoshells and Their Use for Sensitive Optical Glucose Sensing. Advanced Materials 24(13):1736-1740.

291. Li H, et al. (2010) Highly sensitive and selective tryptophan colorimetric sensor based on 4,4bipyridine-functionalized silver nanoparticles. Sensors and Actuators B: Chemical 145(1):194199.

292. Yun W, et al. (2016) Ultrasensitive visual detection of DNA with tunable dynamic range by using unmodified gold nanoparticles and target catalyzed hairpin assembly amplification. Biosensors and Bioelectronics 77:421-427.

293. Baetsen-Young AM, et al. (2018) Direct colorimetric detection of unamplified pathogen DNA by dextrin-capped gold nanoparticles. Biosensors and Bioelectronics 101:29-36.

294. Gopinath SCB, Lakshmipriya T, \& Awazu K (2014) Colorimetric detection of controlled assembly and disassembly of aptamers on unmodified gold nanoparticles. Biosensors and Bioelectronics 51:115-123.

295. Rajamanikandan R \& Ilanchelian M (2017) Simple and visual approach for highly selective biosensing of vitamin B1 based on glutathione coated silver nanoparticles as a colorimetric probe. Sensors and Actuators B: Chemical 244:380-386.

296. Du J, Du H, Li X, Fan J, \& Peng X (2017) In-situ colorimetric recognition of arylamine based on chemodosimeter-functionalized gold nanoparticle. Sensors and Actuators B: Chemical 248:318-323.

297. Kuang L, et al. (2017) Bio-dots assembly-induced aggregation of gold nanoparticles for highly sensitive and selective colorimetric detection of methionine. Sensors and Actuators B: Chemical 244:1031-1036.

298. Huang P-C, Gao N, Li J-F, \& Wu F-Y (2018) Colorimetric detection of methionine based on antiaggregation of gold nanoparticles in the presence of melamine. Sensors and Actuators $B$ : Chemical 255:2779-2784.

299. Chen Y-Y, et al. (2019) A novel pillar[5]arene-based chemosensor for dual-channel detecting L-Arg by multiple supramolecular interactions. Dyes and Pigments 171:107706.

300. Farhadi K, Forough M, Pourhossein A, \& Molaei R (2014) Highly sensitive and selective colorimetric probe for determination of I-cysteine in aqueous media based on $\mathrm{Ag} / \mathrm{Pd}$ bimetallic nanoparticles. Sensors and Actuators B: Chemical 202:993-1001.

301. Wang Y, et al. (2018) A dual-mode probe for colorimetric and fluorometric detection of cysteine based on phosphorus/nitrogen co-doped CQDs and gold nanorods. Sensors and Actuators B: Chemical 273:1627-1634.

302. Xianyu Y, Xie Y, Wang N, Wang Z, \& Jiang X (2015) A Dispersion-Dominated Chromogenic Strategy for Colorimetric Sensing of Glutathione at the Nanomolar Level Using Gold Nanoparticles. Small 11(41):5510-5514.

303. Li J-F, Huang P-C, \& Wu F-Y (2017) Highly selective and sensitive detection of glutathione based on anti-aggregation of gold nanoparticles via $\mathrm{pH}$ regulation. Sensors and Actuators B: Chemical 240:553-559. 
304. Wei L, et al. (2015) Colorimetric assay for protein detection based on "nano-pumpkin" induced aggregation of peptide-decorated gold nanoparticles. Biosensors and Bioelectronics 71:348352.

305. Chang C-C, et al. (2016) Aptamer-based colorimetric detection of proteins using a branched DNA cascade amplification strategy and unmodified gold nanoparticles. Biosensors and Bioelectronics 78:200-205.

306. Chen Z, et al. (2014) A colorimetric aptamer biosensor based on cationic polymer and gold nanoparticles for the ultrasensitive detection of thrombin. Biosensors and Bioelectronics 56:46-50.

307. Li N, et al. (2017) Tuning gold nanoparticles growth via DNA and carbon dots for nucleic acid and protein detection. Sensors and Actuators B: Chemical 251:455-461.

308. Huo Y, et al. (2016) A sensitive aptasensor for colorimetric detection of adenosine triphosphate based on the protective effect of ATP-aptamer complexes on unmodified gold nanoparticles. Biosensors and Bioelectronics 78:315-320.

309. Moitra P, Alafeef M, Dighe K, Frieman MB, \& Pan D (2020) Selective Naked-Eye Detection of SARS-CoV-2 Mediated by N Gene Targeted Antisense Oligonucleotide Capped Plasmonic Nanoparticles. ACS Nano 14(6):7617-7627.

310. Wei X, Wang Y, Zhao Y, \& Chen Z (2017) Colorimetric sensor array for protein discrimination based on different DNA chain length-dependent gold nanoparticles aggregation. Biosensors and Bioelectronics 97:332-337.

311. Najafzadeh F, Ghasemi F, \& Hormozi-Nezhad MR (2018) Anti-aggregation of gold nanoparticles for metal ion discrimination: A promising strategy to design colorimetric sensor arrays. Sensors and Actuators B: Chemical 270:545-551.

312. Sener G, Uzun L, \& Denizli A (2014) Colorimetric Sensor Array Based on Gold Nanoparticles and Amino Acids for Identification of Toxic Metal Ions in Water. ACS Applied Materials \& Interfaces 6(21):18395-18400.

313. Bigdeli A, et al. (2017) Nanoparticle-based optical sensor arrays. Nanoscale 9(43):1654616563.

314. Tan L, et al. (2016) Dual channel sensor for detection and discrimination of heavy metal ions based on colorimetric and fluorescence response of the AuNPs-DNA conjugates. Biosensors and Bioelectronics 85:414-421.

315. Sun J, et al. (2020) Colorimetric sensor array based on gold nanoparticles: Design principles and recent advances. TrAC Trends in Analytical Chemistry 122:115754.

316. Mao J, et al. (2016) Multidimensional colorimetric sensor array for discrimination of proteins. Biosensors and Bioelectronics 86:56-61.

317. Yang X, et al. (2014) DNA-Gold Nanoparticle Conjugates-Based Nanoplasmonic Probe for Specific Differentiation of Cell Types. Analytical Chemistry 86(6):3227-3231.

318. Ghasemi F, Hormozi-Nezhad MR, \& Mahmoudi M (2015) A colorimetric sensor array for detection and discrimination of biothiols based on aggregation of gold nanoparticles. Analytica Chimica Acta 882:58-67.

319. Li D, et al. (2015) Colorimetric sensor array with unmodified noble metal nanoparticles for naked-eye detection of proteins and bacteria. Analyst 140(22):7672-7677.

320. Fahimi-Kashani N \& Hormozi-Nezhad MR (2016) Gold-Nanoparticle-Based Colorimetric Sensor Array for Discrimination of Organophosphate Pesticides. Analytical Chemistry 88(16):80998106.

321. Mohseni N, Bahram M, \& Baheri T (2017) Chemical nose for discrimination of opioids based on unmodified gold nanoparticles. Sensors and Actuators B: Chemical 250:509-517.

322. Mulpur P, Yadavilli S, Rao AM, Kamisetti V, \& Podila R (2016) MoS2/WS2/BN-Silver Thin-Film Hybrid Architectures Displaying Enhanced Fluorescence via Surface Plasmon Coupled Emission for Sensing Applications. ACS Sensors 1(6):826-833. 
323. Li X, Wang Y, Luo J, \& Ai S (2016) Sensitive detection of adenosine triphosphate by exonuclease III-assisted cyclic amplification coupled with surface plasmon resonance enhanced fluorescence based on nanopore. Sensors and Actuators B: Chemical 228:509-514.

324. Inokuchi Y, et al. (2015) New insights into metal ion-crown ether complexes revealed by SEIRA spectroscopy. New Journal of Chemistry 39(11):8673-8680.

325. Langer J, et al. (2020) Present and Future of Surface-Enhanced Raman Scattering. ACS Nano 14(1):28-117.

326. Sugano K, Ikegami K, \& Isono Y (2017) Characterization method for relative Raman enhancement for surface-enhanced Raman spectroscopy using gold nanoparticle dimer array. Japanese Journal of Applied Physics 56(6S1):06GK03.

327. Zhang R, et al. (2013) Chemical mapping of a single molecule by plasmon-enhanced Raman scattering. Nature 498(7452):82-86.

328. Wood CS, et al. (2019) Taking connected mobile-health diagnostics of infectious diseases to the field. Nature 566(7745):467-474. 